WISDOM AND THE MORAL LIFE:

THE TEACHINGS OF AMBROSE OF MILAN

\begin{abstract}
Margaret Elizabeth Mohrmann
Charlottesville, Virginia
\end{abstract}

B.S., College of Charleston, 1969

M.D., Medical University of South Carolina, 1973

A Dissertation Presented to the Graduate Faculty of the University of Virginia

in Candidacy for the Degree of

Doctor of Philosophy

Department of Religious studies

University of Virginia

January, 1995

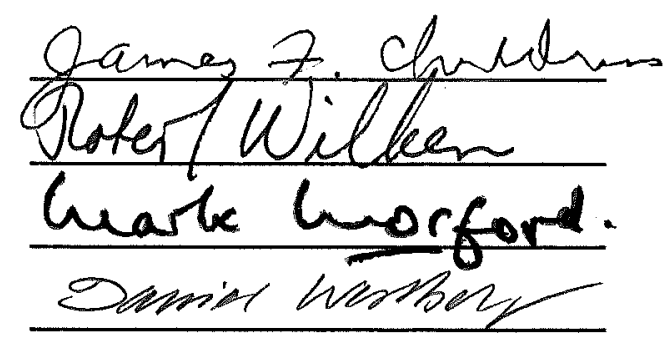


Diss.

Relig.

Studies

1995

. 1963 
(C) Copyright by Margaret E. Mohrmann All rights reserved January， 1995 
WISDOM AND THE MORAL LIFE:

THE TEACHINGS OF AMBROSE OF MILAN

\begin{abstract}
Ambrose, the fourth-century Bishop of Milan, has generally been viewed from the standpoint of his effect on church-state relations in the Middle Ages and on the conversion of Augustine, rather than from the perspective of his own theological and moral teachings. Studies of Ambrose's writings have shown both the pervasive influence of recognizably philosophical ideas and a consistent rejection of philosophy, a conjunction considered paradoxical and problematic by his critics.

This dissertation, by means of a thorough analysis of Ambrose's sermons and essays, displays his understanding of the proper work of reason, the error of philosophy, the nature of Christian wisdom, and the central importance of biblical exempla for both philosophy and christian thought. The analysis shows that Ambrose's acceptance of philosophical formulas and ways of reasoning in the face of his adamant opposition to philosophy as a way of life in competition with the way of Christian wisdom is not paradoxical, but is rather a clear expression of his conviction that philosophy's truths are originally derived from the Hebrew bible and may, therefore, be reclaimed by Christianity as the rightful possessor and interpreter.
\end{abstract}


For Ambrose, the way of Christian wisdom -- the true philosophy, in contrast to various aberrant ways of life centered upon merely human wisdom -- is entered upon and sustained by faith. It entails cosmological and moral knowledge that is available only by reason's discerning reflection on the paradigmatic and revelatory stories of scripture. The biblical narratives of creation and redemption and of the lives of the exempla reveal the truths from which the earliest philosophers constructed their systems of thought. For the faithful, those stories, and reason's interpretation of them, are illuminated by the indwelling presence of Christ, who is himself the way and the Wisdom of God. Such knowledge is not now accessible by philosophy, which has lost its ability to attain true wisdom because it has severed its roots in divine truth and is, therefore, lost in fruitless dialectical debates. 
TABLE OF CONTENTS

Chapter one: Introduction

1. A biographical sketch 1

2. Ambrose's writings 5

3. Writings about Ambrose 9

4. Ambrose and philosophy 14

Chapter Two: The Role of Reason

Ambrose as Philosopher

1. The status of reason 38

2. Vigor mentis $\quad 44$

3. What reason does 47

a. Restraint of passion $\quad 59$

b. Practice and striving 67

c. Perfecting and ascent 71

Chapter Three: The Limits of Reason

Ambrose as Antiphilosopher

1. Reason and God 84

2. The limits of reason 89

3. Human wisdom and divine wisdom 92

4. The nature and result of reason's error

a. The primary error: forgetting the source 103

b. The result of the error 109

Chapter Four: Christian Wisdom

1. The true source

a. Timor domini 119

b. Verbum dei 124

2. The authority of scripture 134

3. The primacy of faith 138 
Chapter Four (cont'd.)

4. Wisdom as the way 143

5. Gathering the secrets of wisdom 157

Chapter Five: The Role of Exempla

1. "Examples rather than precepts" 165

2. De officiis ministrorum 171

a. Exempla as Ambrose's method 172

b. Exempla as source of moral knowledge 174

3. Beyond exempla 187

a. Christ, the perfect example 190

b. Exemplars in the shadow 194

Chapter Six: Conclusion

1. Reading Ambrose

a. Ambrose and philosophy 200

b. Ambrose's Christian philosophy 202

c. Misleading metaphors 208

2. Ambrose's way

a. Traditions of reasoning 217

b. Narrative theology and ethics 221

c. Faith, ethics, and the role of Christ 225

d. The way of wisdom 229

Bibliographic abbreviations 233

Ancient works cited $\quad 233$

$\begin{array}{lr}\text { Reference list } & 236\end{array}$ 
CHAPTER ONE

INTRODUCTION

\section{A biographical sketch}

Ambrose of Milan, a dominant figure in the Western Church in the second half of the fourth century, a bishop whose actions and teachings continued to exert a shaping influence on the Church throughout the Middle Ages and beyond, was the youngest child in a prominent Roman family. His father, Aurelius Ambrosius, was Praetorian Prefect of the Gauls and governed the Gallic territories of the Roman Empire from the imperial seat in Trier where Ambrose was born, probably in the year 339. Upon his father's death, the family returned to Rome, at some time before 353, and Ambrose completed his education there.' Given both the family's patrician standing and the style and content of Ambrose's writings, it can be assumed that he received the education of an aristocratic Roman man. Although there continues to be controversy over just what works Ambrose may have read during and after his school years, there is little question that he had a firm grounding in the literary and philosophical writings of Latin and Greek authors, as well as in the techniques and

1 The biographical material summarized in these pages comes primarily from Dudden (1935), with confirmation and additional information from Paredi (1964) and from the briefer biographies offered by Palanque (1933) and Campenhausen (1964). 
uses of rhetoric. It is likely that his education differed little from that described by Marrou (1958) in reference to Augustine, with the exception that Ambrose's mastery of the Greek language clearly surpassed Augustine's halting acquaintance. ${ }^{2}$

While Ambrose was being educated in the traditional fashion of the Roman aristocracy to prepare him for a career as a lawyer in the imperial court, he was also being reared in a christian family. Because his presumed destiny was a secular and not an ecclesiastical career, the future bishop's religious education was not extensive (Dudden 1935, 1:58); nonetheless, the Christian influence on his youth was surely a strong one, since he lived in a family known for its devotion to religion. His sister Marcellina, the eldest child in the family, gave herself to the church in 353 as a consecrated virgin and, along with their mother and another Christian virgin, practiced a strict religious asceticism in the home in which the adolescent Ambrose lived. Ambrose himself speaks of a relative, the virgin sotheris, who had been martyred in an

2 Marrou 1958, 27-37; Brown 1967, 83-4. The first section of Marrou's work (1958, especially 125-57) details Augustine's exposure to grammar and rhetoric, including wide reading in Latin authors, then to more advanced and eclectic studies in history, geography, natural history, and in the moral and rhetorical points to be gleaned from mythical and historical exempla. Testard (1984, 1:10-1) gives an interesting brief comparison of Ambrose and Augustine as students. 
earlier persecution of Christians (De virginibus 3.38, Exh, virg. 82).

In 370 , after a few years spent in Sirmium as a court lawyer, Ambrose was appointed governor of the province of Aemilia-Liguria and moved to the regional administrative offices in Milan. At that time Milan, rather than Rome, was the imperial seat of the Western Roman Empire. Perhaps because of that fact, the bishopric of Milan, which oversaw all of northern Italy, rivalled that of Rome in its status and influence within the Church (Dudden $1935,1: 62-4)$.

When Auxentius, the Arian Bishop of Milan, died in 373 , the selection of his successor became an acrimonious struggle between his Arian supporters and those who accepted the formulations of the Council of Nicaea. Ambrose, in his concern to prevent the verbal animosity from becoming a physical battle, attended the selection session in the cathedral and was there spontaneously acclaimed bishop by the congregration as a whole. Although Ambrose tried to convince the people that they were in error, the immediate approval of the Emperor Valentinian $I$, the fervor of the congregation, and the power of such a call for this Christian courtier apparently compelled him to accept the election. ${ }^{3}$ During

3 Dudden 1935, 1:64-8; Duval 1976. Courcelle (1973, 916) examines the claim made by Paulinus, Ambrose's fifthcentury biographer, that one of Ambrose's attempts to escape 
one week near the end of the year 373, Ambrose was baptized, ordained, and then consecrated Bishop of Milan. He served in that office until his death in 397 , in the early hours of the day before Easter.

Ambrose's rapid and unforeseen ascent to the episcopal seat in Milan left him in the position of being the chief pastor and teacher for this eager but doctrinally divided flock, lay and clerical. He brought to the task a rich classical education, several years of legal and political experience, and a firm Christian -and Nicaean -- faith, but little religious instruction from which to draw. Several years later, as he wrote his treatise on moral obligations for the clergy, he eloquently recalled the difficulty of being required to teach that which he had yet to learn himself and his hope that the act of teaching would itself enable him to learn. ${ }^{4}$ It appears that the new bishop embarked on a

the congregation's call was by asserting that he wished to profess philosophy; in so doing, Courcelle draws conclusions about both Ambrose's reluctance to take on the office and his attraction to philosophy. The matter is discussed further by Duval (1976, 263-72).

4 De off. min. 1.3-4 (PL 16, 24A-25A): ". . . sed tantummodo intentionem et diligentiam circa scripturas divinas opto assequi, quam ultimam posuit Apostolus inter officia sanctorum, et hanc ipsam ut docendi studio possim discere. Unus enim verus magister est, qui solus non didicit quod omnes doceret: homines autem discunt prius quod doceant, et ab illo accipiunt quod aliis tradant. Quod ne ipsum quidem mihi accidit. Ego enim raptus de tribunalibus atque administrationis infulis ad sacerdotium, docere vos coepi, quod ipse non didici. Itaque factum est ut prius docere inciperem, quam discere. Discendum igitur 
concerted effort to fill the gaps in his knowledge by extensive study of the scriptures and of Jewish and Christian writings, with a particular emphasis on the works of Philo, Origen, and his contemporary, Basil of Caesarea (Dudden 1935, 1:113).

\section{Ambrose's writings}

Throughout his tenure as bishop, Ambrose remained primarily a preacher and pastor; from the evidence of his extant works, it appears that he never attempted to produce a systematic theology. The majority of his writings are sermons which were more or less carefully brought together into forms suitable for publication. Even the works that were probably never preached are consistent with Ambrose's homiletic style of persuasive, exhortatory pedagogy and are not orderly explications of fully developed doctrines. ${ }^{5}$

The dating of many of Ambrose's works remains controversial or imprecise (Quasten 1986, 152-79); the detailed chronology presented by Palanque (1933, 480-581)

mihi simul et docendum est; quoniam non vacavit ante discere."

5 Nauroy 1985b, 374: "Son oeuvre écrite est presque toute issue de sa prédication, et même là où l'on peut soupçonner, sans en être d'ailleurs certain, qu'on lit un texte directement rédigé sans l'étape préalable d'un discours oral, la forme, plus serrée, plus érudite parfois, continue d'imiter les particularités du propos parlé." A detailed technical analysis of Ambrose's homiletic style is presented in Oberhelman (1991). 
is the one against which most arguments are brought (for example, Savon 1970), perhaps because of the author's assertions of certainty. In some instances, accurate dating of particular works could be useful for a fuller understanding of Ambrose's thought. For example, Palanque claims that Ambrose's commentary on Psalm 119, a series of at least 22 sermons, was preached between May 13, 389, and February 3, 390; he also places the final composition of De officiis ministrorum in the second half of 389. This assumption creates the tantalizing picture, upon which Palanque himself does not comment, of Ambrose working simultaneously on his two richest moral writings and the consequent possibility of scholars' drawing closer connections between two works which, at first glance, seem so different in style and content, yet may have occupied Ambrose at the same time. However, other researchers have placed the De officiis ministrorum at many different times within Ambrose's bishopric, and the only consensus about Expositio psalmi CXVIII is that the series of sermons were preached between 386 and $390,{ }^{6}$ so the tantalizing picture remains no more than that.

6 Quasten $(1986,167)$ acknowledges possible dates for De officiis ministrorum from 377 to 391 , and adds, "[t]he attempt of Palanque to assign the work in the second half of 389 is not convincing." on the dating of Expositio psalmi CXVIII, see Quasten (1986, 163) and Petschenig's introduction to the critical edition (CSEL 62:vi). 
On the other hand, a thorough reading of Ambrose's work reveals such thematic consistency throughout that the issue of chronology may not be very important in the final analysis. Three of his five essays on virginity (De virginibus, De viduis, De virginitate) were preached and published in the years $377-378$; the other two (De institutione virginis, Exhortatio virginitatis), which differ not at all from the earlier ones in terms of Ambrose's beliefs and pedagogical aims, appeared between 391 and 394. The specifically anti-Arian treatises (De fide, De spiritu sancto, De incarnatione) were among his first works (published between 378 and 382), but antiArian arguments and sharp reminders of Nicaean doctrine arise at every opportunity throughout his writings, including the commentaries on the psalms written in his last years (see, for example, Explan. ps. 36 35-7 and Explan. ps. 39 18).

The influence of Philo, so evident in some of Ambrose's earliest writings -- for example, De paradiso, which probably appeared in 377 -- is there still (or again) in one of his later works, De fuga saeculi.?

7 Palanque (1933, 549-50) puts the publication of De fuga in 394 , but Savon (1977b, 1:17) says only that it must have appeared after 388 or 391 . Savon then rejects an argument that, on the assumption of a sort of irreversible mental shift in Ambrose from Philo to Plotinus, would put De fuga before 386; Savon writes (1977b, 1:18): "On peut supposer que la source utilisée par 1 'évêque de Milan dépend moins de son évolution intellectuelle que du sujet qu'il veut traiter et des documents dont il dispose à cet effet." 
Demonstrations of Platonic and Neoplatonic influences on Ambrose's thought and expression generally focus on four works written in the second half of his bishopric, in 386 and later $^{8}$-- De Jacob, Exameron, De Isaac, and De bono mortis -- but also show those influences appearing as early as Ambrose's first published work, De excessu fratris, a eulogy preached for the funeral of satyrus, his beloved brother and aide, in 375 (Courcelle 1968, 319-36; $1976,175-8)$.

In general, throughout this dissertation Ambrose's thematic consistency or, one might say, his singlemindedness both makes possible and is demonstrated by the fact that points to be made about his thought can be illustrated by passages culled from the entire spectrum of works written during his 23-year bishopric. Just as Madec (1974c, 96) found no change during that time in Ambrose's opposition to philosophy, so there is also no substantive change in his professed beliefs about Christ, morals, asceticism, scripture -- all favored topics -- or in his methods of presentation. Nauroy $(1985 b, 372)$ notes progress through time, like stages of apprenticeship, in Ambrose's exegetical skills. However, even as Ambrose becomes an increasingly adept interpreter, it remains

8 Courcelle $1956,1962,1963,1964,1968$ (93-138, 31182), 1973 (25-33), and 1976 (171-84); Solignac 1956; Hadot 1956; Sagot 1974; Nauroy 1974, 1985a. See also Madec 1974c, 109-32 and 166-71. 
clear that the truths he seeks and finds in scripture and the basic methods of his search do not change.

\section{Writings about Ambrose}

Ambrose's place in the history of the Western Church seems often to be based on two facts about his tenure as bishop. First, he asserted the power of the Church vis-àvis the power of the Emperor, through a series of dramatic confrontations, and thereby initiated an understanding of church-state relations that formed the practical basis of the politically powerful medieval papacy. Thus, Ambrose's work has been analyzed and remembered in regard to his role as Kirchenpolitiker. ${ }^{9}$

Second, his allegorical and typological interpretations of the stories of the Hebrew Bible removed obstacles to Augustine's acceptance of Christianity (Brown 1967, 82-6). Ambrose baptized Augustine at the end of Holy Week in the year 387. As an apparent consequence of Ambrose's propaedeutic role and of Augustine's later overshadowing importance for the Church, Ambrose's writings are often studied primarily through the lens of

9 See, for example, Campenhausen (1929) and Dudden (1935). Continuing affirmation of this view of Ambrose can be seen in Frend (1982, 178-87), Walker (1985, 159-60), and Cantor $(1993,73)$. 
Augustine's theological achievements, for the purpose of tracing influences or drawing comparisons. ${ }^{10}$

Failure to look beyond these two prominent aspects of Ambrose's role and contribution has many times relegated him to little more than a passing mention in discussions of the history of the church and the development of Christian theology, ${ }^{11}$ and of the history of christian moral thought, ${ }^{12}$ despite his status in the Middle Ages as one of the four "doctors" of the Church.

Although Ambrose's political activities and effects continue to comprise the greater part of biographical materials about him, and although the field of Augustinian studies continues to form the academic background for most Ambrosian studies, research interest in Ambrose during the

10 See, for example, Holte (1962) and Madec (1974c, 1977); in Savon's review (1977c, 182ff) of Madec's book the latter's Augustinian focus is noted and criticized (see also Courcelle 1976 , 186).

11 There are multiple scattered references to Ambrose in the ecclesiastical histories of Chadwick (1967), Pelikan (1971), and Herrin (1987), and brief mentions in the general and intellectual histories of Previté-Orton (1952, 68-71), Artz (1953, 78-9), and Cantor (1993, 70-4).

12 In Forell's History of Christian Ethics (1979), there are two pages (couched within the chapter on Augustine) devoted to Ambrose as the Christianizer of ciceronian ethics. Ambrose is generally absent altogether from anthologies of christian ethical writings -- see, for example, Forell (1966) and Beach and Niebuhr (1973) -- and is also missing from Ernst Troeltsch's influential study (1981) of the historical development of Christian social teachings. It is ironic in this regard that cantor, in his history of the Middle Ages (1993, 261), attributes to Ambrose the only transmission of "a Christian social gospel" from early Christianity to medieval civilization. 
past 150 years has, for the most part, concentrated on three other areas. First, there has been an enduring fascination with the parallels between Ambrose's De officiis ministrorum and Cicero's De officiis; the resulting comparative discussions have framed -- and limited -- most descriptions and analyses of Ambrose's moral thought.

As one of those comparative analysts has explained (Hiltbrunner 1964, 174), a scholarly competition sponsored by the University of Munich in 1864 stimulated a renewed interest in the linkage between the two treatises, resulting in a number of publications, the most influential of which have been those of Ewald (1881) and Thamin (1895). Although long since superseded in many ways, Ewald's display of apparently stoic traces in Ambrose's work and, more important, Thamin's exposition of the new Christian moral notions that Ambrose blended ${ }^{13}$ with those of Cicero and his philosophical ancestors, have been fertile sources for later studies. Those subsequent efforts have generally followed the traditional comparative approach, viewing Ambrose's De officiis -- and often equating that work with his moral thought as a whole

13 Thamin most often uses metaphors of synthesis and alliance (see, for example, p.203) when describing the relation of Ambrose's thought to that of Cicero, but also can speak in terms of addition or superimposition (see pp. 252-3). 
-- through the lens of Cicero's De officiis. ${ }^{14}$ As

steidle's work suggests, the consistent use of a

ciceronian lens when examining Ambrose's ethics is as

potentially problematic as the Augustinian bias mentioned

above.

With this strongly ciceronian focus, although many of the studies of De officiis ministrorum include occasional supportive passages from others of Ambrose's works, scholarly investigation of his contributions to the development of Christian ethics has not moved beyond the De officiis sufficiently to attempt an encompassing and synthetic description of the dominant moral understanding that informs and permeates all of Ambrose's writings. ${ }^{15}$

14 Muckle (1939) described the "Christianization" by Ambrose of Cicero's moral terms, and Deman (1953) carried forth Muckle's work by attempting to show the significance of Ambrose's accomplishment for the development of Christian moral theology. Testard's 1973 analysis of Ambrose's understanding of conscientia, based on the text of De officiis ministrorum, is written in the light of Cicero's work, and his later explicitly comparative studies (1974, 1989) make clear that his primary criticism of Ambrose's thought and modes of expression is that Ambrose is not Cicero (much as Madec's assessment of Ambrose is that he is not Augustine). Other notable comparative studies include the aforementioned work of Hiltbrunner (1964) and those of K. Zelzer (1977), Gaffney (1981), steidle (1984, 1985), and Colish (1990). Hagendahl (1958, 347-81) deals specifically with the four cardinal virtues transmitted by Ambrose from pagan thought to Christianity, as does Mähl (1969, 7-14).

15 See, for example, Holte $(1962,148,165-75)$ for a view of Ambrose as primarily preoccupied with matters of morality (rather than cosmology). In Holte, as in the others who make this point (Gilson 1952, 113; Courcelle $1968,94-5)$, the ethical emphasis is acknowledged but not examined. Brown's (1988, 341-65) study of Ambrose's ethical views focuses specifically on matters of sexual conduct and 
The second area of research concentration is the putative influence of various other non-Christian writers and philosophical schools on Ambrose's ideas. Nineteenthcentury studies which analyzed the Ambrose-Cicero connection often also considered other evidences of Stoicism in Ambrose's thought, but it was in the second half of the twentieth century that this area of investigation into non-Christian influences expanded remarkably. Since 1950, there has been extensive research into Ambrose's indebtedness to Philo (Lucchesi 1977, Savon 1977b) and to Plato, Plotinus, and Neoplatonic thought (see n.8), and into his attitude towards and selective adoption of the various philosophical systems that were part of his education and intellectual milieu (Holte 1962, Madec 1974C, Nauroy 1974, Ellspermann 1984). Related to the interest in Philonian and Platonic vestiges in Ambrose's writings are studies of his extensive use of allegorical exegesis, emphasizing both his place within that tradition of interpretation and the illumination the method gives to Ambrose's conviction of the absolute truth of scripture (Savon 1977a, 1984; Pizzolato 1978; Nauroy 1985a, 1985b; Jacob 1990).

Third, a review of recent literature also reveals a burgeoning interest in Ambrose as liturgist, focusing on his contributions to Christian hymnody and the structure virginal integritas. 
of the mass, including the introduction of Eastern Church practices of psalm-chanting and congregational singing, and to the Church's teaching on the sacraments. ${ }^{16}$

\section{Ambrose and philosophy}

Among all the investigations of Ambrose's writings, the one that has come closest to attempting an embracing, comprehensive view of his thought is that of Goulven Madec. His book, Saint Ambroise et la philosophie, which appeared in 1974, was originally written to satisfy requirements for the doctorate, under the tutelage of Pierre courcelle, and built directly on the research, undertaken by Courcelle and others, that explored evidences of philosophical influences on Ambrose's thought and expression. Madec's intent was to reconcile an apparent paradox revealed by those studies: Ambrose was, in practice, a disciple of certain philosophers while at the same time being, in principle, an enemy of philosophy. ${ }^{17}$ That is, as the extent of Ambrose's

16 Dudden 1935, 1:286, 293; Artz 1953, 86-7, 93. Chadwick (1993) and Dalmais (1993) discuss Ambrose's influence on hymnody in their reviews of a collection of the bishop's hymns. Mohrmann (1976) has analyzed the style of Ambrose's De sacramentis and De mysteriis; a recent edition of those works is reviewed by Anderson (1993).

17 Madec 1974c, 12: "Ambroise serait donc un disciple de fait de philosophes et un ennemi de principe de la philosophie." Compare Holte $(1962,131)$ : "Bien qu'il n'ait jamais rien de positif à mettre au compte des philosophes, Ambroise n'en est pas moins lui-même un philosophe éclectique assidu." 
"borrowings" from particular philosophers and from the general philosophical milieu of his time became more evident to scholars, the common characterization of him as an unwavering opponent of all philosophy ${ }^{18}$ had to be, if not called into question, at least reexamined as perhaps a more complex issue than had been suspected.

Madec's method was to comb all Ambrose's extant works meticulously for references, even if somewhat veiled, to philosophy or philosophers. He then used the resulting 184 passages as the framework for his discussion, without specifically analyzing most of the excerpts themselves. The body of the work is in four parts. First, Madec traces through Ambrose's writings, roughly in chronological order, to demonstrate the bishop's criticisms of philosophy and his consistent charge that any good or useful philosophical notions were "borrowed" from the Hebrew Bible, the scriptures claimed by Christians. As one outcome of that effort, Madec finds no significant evolution in Ambrose's negative attitude toward philosophy during his episcopal tenure (96). Although the severity of his judgments may vary, Ambrose remains consistently opposed to philosophical practices and aims, and seldom misses an opportunity to put

18 See, for example, Gilson (1952, 112: "Ambroise ne pensait aucun bien des philosophes"); Dudden (1935, 1:16 n.1: "Ambrose is fanatical in his refusal to allow merit to pagan thinkers"); and Testard (1975, 215: "le rejet massif des philosophes et de leurs thèses"). 
philosophy in a markedly inferior position relative to Christian belief and conduct.

In his second chapter, Madec takes a different approach and reports evidence of Ambrose's knowledge and use of various philosophers and philosophical schools, from the "barbarians" (Chaldeans, Egyptians) through Plato to Cicero and later Platonists. The author's conclusion throughout is that the undeniable traces, explicit or not, of philosophical thought are superficial and do not affect Ambrose's doctrinal ideas (175). His Platonism is only rhetorical, a matter of borrowed anecdotes and metaphors (130-2); Cicero's writings provide a framework only, not a source of moral theory $(161-5,175)$.

It is in the conclusion to this second chapter (1745) that Madec presents the first indication of an explanatory theory that informs his study. He calls upon a statement by Tissot, the translator and introducer of Ambrose's commentary on the gospel of Luke, concerning Ambrose's relation to the writings of his christian predecessors : ${ }^{19}$

One sometimes has the feeling that the reading of models is above all, for the Bishop of Milan, an awakening of ideas. He listens to Origen, Eusebius

19 Tissot 1971, 1:17: "On a parfois 1'impression que la lecture des modèles est avant tout, pour l'évêque de Milan, une éveilleuse d'idées: il écoute origen, Eusèbe ou Hilaire, il enregistre et retient leurs expressions; mais pendant tout ce temps il a suivi sa propre pensée, et il arrive qu'avec les mêmes mots il construise un raisonnement assez différent, parfois même diamétralement opposé." 
or Hilary; he takes them in and remembers their expressions. But the whole time he has pursued his own thought and it happens that with the same words he constructs an argument that is quite different, sometimes even diametrically opposed.

Madec believes this notion of purely verbal imitation applies to Ambrose's use of philosophers' terms: Ambrose has taken words, metaphors, and conceptual frameworks from earlier, non-Christian thinkers (especially Plato and Cicero) but has left their substantive ideas behind. Hiltbrunner also employed this notion when he asserted, in a different metaphor, that Ambrose retained the basic framing structure of the (largely stoic) house built by cicero in his De officiis, but completely refurnished the interior of the house, making it quite a different place in which to live. ${ }^{20}$ Madec occasionally employs that framework image, but more often uses the metaphorical idea of a word as a more or less hollow transport vessel into which meaning can be loaded and from which it can be extracted, leaving the vessel itself apparently unchanged and essentially meaningless.

In developing this theory, Madec speaks of Ambrose's "extraordinary and disconcerting" ability to empty

20 Hiltbrunner 1964, 178: "Es ist der formale Rahmen als solcher bewahrt oder, um im Gleichnis zu bleiben, es ist immer wieder ein und dasselbe Haus, das für die Bedürfnisse eines neuen Bewohners umgebaut wird. Die Fassaden bleiben stehen, die Veränderungen gehen hinter ihnen vor sich. Von aussen gesehen sind die sätze und das System der stoa noch bei Ambrosius kaum verändert. Wir müssen schon ins Innere eintreten, um da der völligen Verwandlung gewahr zu werden." 
philosophical formulas of their content and then to appropriate them in a sense suitable for his own uses, a technique that is better characterized as substitution than as any sort of ideological synthesis. ${ }^{21}$ This idea is discussed again in the general conclusion to Madec's book (343-4), where it is expressed as a dissociation of verba and res.

Madec's third chapter is entitled "Christian wisdom," and in it the author intends to display Ambrose's idea of Christian, biblical wisdom as the standard against which he judges philosophy. ${ }^{22}$ The chapter explores various components of Ambrose's notion of wisdom, including biblical truth, the importance of scriptural exempla, and the primacy of faith, but arrives at no cohesive summary of Ambrose's understanding of Christian wisdom, only a return to the emphasis on his conviction of the absolute truth of scripture (245).

${ }^{21}$ Madec 1974C, 175: "Ambroise me semble en effet avoir été doué d'une aptitude extraordinaire et déconcertante à vider les formules de leur substance, pour se les approprier dans le sens qui lui convenait ou qu'il estimait vrai. Or il s'agit là d'un procédé de substitution, et non pas de synthèse doctrinale." In arguing against seeing Ambrose's task (or achievement) as a true doctrinal synthesis, Madec is implicitly countermanding both Thamin (1895) and Deman (1953).

22 Madec 1974C, 19: "Enfin le troisième chapitre constituera un essai pour discerner dans l'idéal ambrosien de la sagesse biblique et chrétienne le critère de ses jugements sur la philosophie." 
Ambrose's lost work, De sacramento regenerationis sive de philosophia, also referred to as De philosophia, is the fourth subject of the book, comprising a second section which includes the fourth and fifth chapters. Madec draws together, primarily from Augustine's writings, all extant references to this work, few and fragmentary as they are, and analyzes their content and implications. His conclusion is that one can only say there is no reason to think the work as a whole would contradict the views of philosophy expressed by Ambrose in his other writings (339).

In Madec's general conclusion (339-46), he claims to have resolved the paradox that originally drove his investigation, and to have done so by diminishing the power of one of its arms. Ambrose's conviction that all philosophical truth finds its source in scripture and his alleged ability to fill evacuated philosophical terms with the Christian content of his choice virtually eliminate the significance of his apparent borrowings from philosophy. He cannot then truly be considered a "disciple, in practice, of philosophers" (see n.17) and his enmity toward philosophy need no longer appear paradoxical.

Without discounting the exhaustive and careful research exhibited and the wealth of resources made available in this book, it must be said that Madec's 
conclusions are less than satisfactory. This is so for a number of reasons, most of which have to do with his method and his assumptions. His decision to examine Ambrose's writings in a piecemeal manner, relying solely on extracts that mention philosophy or a philosopher, rather than to attempt a grasp of Ambrose's thought as a whole is what keeps Madec from attaining a comprehensive insight into the reasoning and attitudes of the Bishop of Milan.

It is Madec's method that makes it possible for him to say, in the first lines of his concluding essay, that the problem of philosophy is marginal in Ambrose's work and his mind, and does not lend itself to attempts at synthesis. ${ }^{23}$ As I shall show in this dissertation, a comprehensive, synthetic understanding of Ambrose's attitude toward philosophy is, in fact, possible, but only from the vantage point of an encompassing view of his work and, most important, of his conception of christian wisdom, in contrast to which philosophy is defined and condemned by the bishop. The apparent marginality of the problem of philosophy can be understood only in relation to the centrality of Christian wisdom or, more accurately, of Christ in Ambrose's thought.

23 Madec (1974c, 339): "Le problème de la philosophie est marginal dans 1 'oeuvre et dans l'esprit d'Ambroise. Il ne se prête pas à la synthèse." 
The anthology of passages Madec has amassed, while potentially useful in other ways, is nevertheless inadequate for the task he undertook precisely because those excerpts have been taken out of context. A thorough reading of Ambrose's works leaves the unshakeable impression, as noted earlier, that he was above all a preacher, given to lengthy but carefully and logically constructed developments of his homiletic themes. It is, therefore, difficult to understand fully particular. expressions, anecdotes, citations, references, or apparent asides within his writings without some notion of how those pieces figure into the whole message he is propounding, without some evidence that the extracted passages represent accurately the sense of the longer project to which they belong.

Savon, in his study of the Philonian influences evident in Ambrose's writings, makes the point as part of his introductory remarks that Ambrose is one of those authors who cannot be read in fragments. The terms Ambrose uses have imprecise meanings that are clear only in their contexts; phrases can seldom be isolated without losing their import. Savon identifies the "passage" (although without clearer definition) that is the heart of a lengthy discourse as the smallest unit of meaning. ${ }^{24}$

24 Savon 1977b, 1:12: "Ce que beaucoup de ces travaux semblent avoir méconnu, c'est précisément ce problème de la 'plus petite unité significative.' . . Les termes dont il 
Thus, in his review of Madec's book, he criticizes a method that tries to understand the whole of Ambrose's thought by looking in what savon considers to be the equivalent of a shattered mirror. ${ }^{25}$

The fragments Madec has assembled are, in fact, seldom analyzed by him in terms of their own content, much less in terms of their role within their original sermon or essay. Rather, their treatment often seems based on the unexamined assumption that most are stereotyped, almost programmatic slurs, inserted casually as the opportunity arose for Ambrose to give his hearers or readers yet another example of the wrong-headedness of philosophy. That is, in seeking Ambrose's attitude toward philosophy, Madec carries out an investigation that seems

[Ambrose] se sert ont un contenu mouvant que l'on ne peut préciser sans l'aide d'un contexte assez large. La phrase est rarement chez lui un tout autonome, une entité stable qui garderait l'essentiel de sa signification, une fois isolée. Elle n'est le plus souvent -- au sens propre du mot -- qu'un passage, au sein d'un développement souvent fort long, qui constitue la véritable unité, et en dehors duquel elle ne saurait être comprise."

${ }^{25}$ Savon 1977c, 187: "Je veux parler de celle [méthode] qui cherche à reconstruire tel aspect d'une doctrine à partir de fragments arrachés aux parties les plus diverses d'une oeuvre. on risque d'aboutir à une sorte de kaléidoscope qui fatigue vite l'attention. Et cela est plus vrai encore lorsqu'il s'agit d'un Ambroise, orateur habitué à exprimer sa pensée beaucoup moins par des formules lapidaires que par de longs développements à structure musicale. Quatre ou cinq lignes détachées de ces grandes unités perdent beaucoup de leur sens, et reconstituer un tout à partir de ces débris est une entreprise risquée, quel que soit le soin apporté à cette recomposition: on voit toujours assez mal dans un miroir brisé." 
to take a particular sort of attitude as an a priori assumption.

The problem of fragmentariness and lack of contextual grasp is made more severe by Madec's limiting his selections to only those which more or less explicitly refer to philosophy or its practitioners. In doing so he has missed large portions of Ambrose's work that are heavily imbued with philosophical ideas and expressions whose apparently deep integration into Ambrose's thought immediately calls into question Madec's dissolution of the Ambrosian philosophical paradox. ${ }^{26}$ For example, there is but one passing reference in Madec's book (1974c, 239 n.297) to De Jacob et vita beata, an essay in which Ambrose presents his idea of the Christian sage by means of a rich and thoughtful intermingling of stoic and Neoplatonic philosophical concepts with biblical themes and characters. ${ }^{27}$

26 Solignac $(1975,489)$ makes this point in his review of Madec's book: "Mais ici l'enquête de G. Madec et son précieux répertoire s'avèrent incomplets. Aux textes relatifs à philosophia et philosophi il eût fallu joindre les textes où apparaissent des notions et des thêmes philosophiques . . ."

27 See Nauroy (1974); on p. 140 Nauroy summarizes that intermingling: "Dans cette présentation éclatée de sa source juive, qui embrasse les fragments inspirés d'Origène, de Plotin et de Philon, s'exprime une attitude intellectuelle qui résume le jugement d'Ambroise sur son double héritage culturel: judaïsme et paganisme ne peuvent utilement converger I'un vers l'autre, la tentative du Juif anonyme, auteur du Panégyrique des Maccabées, qui cherche à la conduite de ses héros des fondements philosophiques empruntés à l'hellénisme, est illusoire, car c'est seulement 
Madec's decision to study Ambrose's thought in such a piecemeal and somewhat blinkered fashion -- tantamount to a decision not to attempt a view of his thought as any sort of whole -- has resulted not only in an inadequate picture of Ambrose's view of philosophy, but also in failure to achieve an encompassing understanding of Ambrose's idea of Christian wisdom, the standard in contrast to which philosophy is both defined and judged by the bishop. It is perhaps due to the deficiencies of his investigatory method that Madec is able to devote some seventy pages to a discussion of Christian wisdom which includes virtually no mention of Christ. Ambrose, most of whose works are strikingly centered on the words and actions and person of Christ, could certainly not do the same. ${ }^{28}$

Another critical aspect of the weakness of saint Ambroise et la philosophie is that Madec's apparent working definition of philosophy is anachronistic,

en confluant dans le christianisme, qui les intègre selon une perspective historique correcte et les dépasse, que ces deux mouvements peuvent fusionner."

The philosophical ideas that fill the first book of De Jacob will be discussed at length in chapter two of this work.

28 Savon (1977c, 186-7) criticizes Madec's failure to recognize Ambrose's Christocentrism. The lengthy analysis by Auf der Maur (1977) of Ambrose's commentaries on various psalms is organized around displaying the bishop's unwavering focus on Christ in his "Christologizing" exegeses. See also Händler's review (1978) of Auf der Maur's work. 
limited, and, as it happens, significantly different from Ambrose's. As regards anachronism, Madec makes much of distinctions among various schools and philosophers, distinctions which would have been puzzling to Ambrose or any other fourth-century thinker (see Meeks 1986, 41; Savon 1977c, 187; Spanneut 1973, 110-2; Courcelle 1964, 131). Moreover, Madec seems to play on the later scholastic distinction between philosophy and theology (see Copleston 1972, 22-6) as he draws the line in the wrong place between philosophy and what Ambrose is doing. Ambrose would, in fact, understand his own reasonings and writings as philosophical in nature -- that is, as driven by a desire for and love of wisdom -- but would quickly insist that only christian philosophy is true philosophy, since only within Christianity is true wisdom to be found. 29

Madec's definition of philosophy generally seems to be limited to metaphysics only, as shown by his use of exclusionary phrases like "properly philosophical

29 See Pannenberg (1976, 7-14) on the ancient understanding of theology as wisdom rather than as a form of specialized knowledge. In one instance (one only, but one nonetheless), Ambrose himself refers to Christianity as "philosophy," specifically the philosophy of the consecrated virgins he is addressing (De virginitate 48). Of additional interest in this regard is Galen's characterization of Christianity, in the second century C.E., as a philosophical school (Wilken 1984b, 72-4). 
reflection. ${ }^{30}$ Thus, he misses the opportunity to understand Ambrose's preoccupation with ethics (see n.15) as being itself a philosophical activity, within the classical definition of philosophy as a multifaceted pursuit encompassing ethics as well as metaphysics and logic (Hadot 1979). Madec's relatively modern and specialized understanding of philosophy may also be what keeps him from appreciating late antiquity's characterization of philosophy as a way of life, a definition that implies not only moral entailments relative to the conduct of that life but a complete personal investment that goes beyond rational assent. ${ }^{31}$

It thus becomes clear that Madec's definition of philosophy is not Ambrose's; they are talking about two rather different things. Madec envisions philosophy as an

30 Madec 1974C, 94: ". . Ambroise n'éprouve que peu d'intérêt pour la réflexion proprement philosophique." Related to this definitional limitation is Madec's separation of rational moral deliberation from the "properly intellectual" function of reason, as will be discussed in the next chapter, and his charge that Ambrose's Christian wisdom includes no "properly intellectual" component (1974c, 244): "On peut ajouter, je crois, sans risquer un démenti, que la sagesse chrétienne, dans l'esprit d'Ambroise, est constituée essentiellement par une 'ascétique' et une 'mystique' . . . mais elle ne comporte pas, du moins à titre d'élément constitutif, une fonction proprement intellectuelle, analogue et, au besoin, opposée à celle que prétend remplir la philosophie."

31 See Wilken (1984a and 1984b, 77-82) and Holte (1962, 18). Savon (1977c, 193-5), as part of his criticism of Madec's book, asserts that Ambrose's objection to philosophy is quite specifically aimed at philosophy in its role as a sort of religion into which one is initiated and which one adheres to by faith in its world view. 
academic, rational pursuit of metaphysical knowledge which Ambrose must find a threat to his fideist acceptance of divine revelation, a threat evoking adamant opposition. Ambrose, on the other hand, as will be shown, sees philosophy as a way of life that can only be a dangerously (damnably) wrong alternative to the way of Christian wisdom, an alternative requiring adamant opposition. The difference in these two characterizations is crucial for understanding and appreciating Ambrose's view of the role of reason, the centrality of ethics, the fundamental importance of scripture, and the meaning of wisdom, as well as his attitude toward non-Christian philosophy. It is tempting, and likely at least partly correct, to see Madec's limitations as a result of his looking at Ambrose through Augustine. Madec is so taken with the difference between these two doctors of the church in their relation to philosophy and their debts to philosophers (whether acknowledged or not) that it seems he cannot help but see Ambrose near the extreme of antirational fideism in contrast to Augustine's highly intellectual Christian philosophizing. ${ }^{32}$ Although such

32 See, for example, Madec (1974C, 91, 244, and 346-7). Savon (1977c, 182-3) gives several other instances of Madec's Augustinian focus. See also Madec's explicit comparison of Ambrose and Augustine in relation to philosophy (1977).

Holte (1962) looks at Ambrose much the same way. Although Augustine is, in fact, his primary subject, Holte's reading of Ambrose seems entirely colored by the contrasts that support his belief that Augustine's Christian 
contrasts can be enlightening, they can also obscure a vision of what Ambrose himself is about as he preaches to his Milanese people and of how that seemingly paradoxical mixture of philosophy and anti-philosophy actually plays itself out in Ambrose's mind, a mind that Augustine, for one, respected, recalling years later Ambrose's sermons and claiming the Bishop of Milan as one of his primary mentors in understanding Christianity. ${ }^{33}$

An analogous problem arises in Testard's research into Ambrose's thought. As he mentions in a laudatory review of Saint Ambroise et la philosophie, Testard (1975, 213), like Madec, came to Ambrose through Augustine. He now finds in Madec's book affirmation of his own rather harsh critical attitude toward Ambrose and welcomes Madec's analysis as completely in accord with his own

philosophical background and influences must lie in the school of Alexandria and not in Ambrose. This thesis overlooks not only Augustine's acknowledged debt to Ambrose but also the marked influence on Ambrose himself of Alexandrian thought, primarily through Philo and origen.

33 As Peter Brown $(1967,408)$ states, "His [Augustine's] own hero was Ambrose." Earlier, ending the chapter of Augustine's biography that deals primarily with Ambrose, Brown writes $(1967,87)$ : "The influence of Ambrose on Augustine is far out of proportion to any direct contact which the two men may have had." See Augustine (Conf. $5.13 .23,6.3 .3-6)$ and Courcelle $(1968,251-3)$. It is interesting in this regard to note that Madec (1974c, 249) acknowledges that it is only because of Augustine that we have any knowledge, however fragmentary, of Ambrose's De philosophia. However, he apparently draws no implications about Augustine's regard for Ambrose's thought from the fact that the Bishop of Hippo deemed the work worthy of reference and transmission; see also Savon (1977c, 179, 182). 
views. As it happens, much of Testard's own analysis and criticism of Ambrose is filtered, though perhaps fundamentally through an Augustinian prism, most directly through a Ciceronian lens.

Testard's detailed studies $(1974,1984,1989)$ of Ambrose's De officiis ministrorum ${ }^{34}$ find the work characterized by nothing so much as incoherence, contradiction, and digression -- in short, by Ambrose's manifest inability to follow the plan he has set himself for the task, Cicero's plan. In response to this consistent dismissal of Ambrose's capabilities as a thinker and writer, steidle, in an equally meticulous examination of De officiis ministrorum (1984, 1985), claims that Ambrose's coherence and consistency -- his indeed considerable compositional skills -- are clear when the work is assessed from the vantage point of Ambrose's plan, not Cicero's.

A telling example of the difference between Testard and steidle in their understanding of Ambrose's thought and procedure is their handling of De officiis ministrorum

34 It is worth noting that Testard's Ambrosian studies appear to have been of De officiis ministrorum only; his judgments of the work, therefore, risk a limitation of perspective analogous to the contextlessness that bedevils Madec's book. 
1.116, where Ambrose most clearly displays his intent in contradistinction to that of cicero: ${ }^{35}$

Some might say that it would have been more fitting to have put these things [the discussion of the four cardinal virtues] first, because from these four virtues arise the various sorts of duties. But that is a matter of artfulness, first to define duty and then to separate it into its classifications. We, however, avoid artfulness; we set forth instead the examples of our ancestors, which present neither uncertainty in regard to what is to be understood, nor guile in what is to be discussed. Let the lives of our ancestors, therefore, be for us a mirror for learning, not material for clever commentary. Let there be reverence in imitating them, not subtlety in discussing them.

Testard claims that here Ambrose has had to face -and apologize for -- the fact that the plan of the work has escaped him. Ambrose attempts to cover his tracks, so to speak, by talking of exempla when, in reality, he is giving up his hopes for a treatise the equal of cicero's and settling for a jumble of bible stories. ${ }^{36}$ steidle, on the other hand, takes Ambrose's words at face value.

35 De off. min. 1.116 (PL 16, 57B-C): "Haec forsitan aliquis dicat primo loco poni oportuisse, quoniam ab his quatuor virtutibus nascuntur officiorum genera. Sed hoc artis est, ut primo officium definiatur, postea certa in genera dividatur. Nos autem artem fugimus, exempla majorum proponimus: quae neque obscuritatem afferunt ad intelligendum, neque ad tractandum versutias. Sit igitur nobis vita majorum disciplinae speculum, non calliditatis commentarium: imitandi reverentia, non disputandi astutia."

36 Testard 1974, 168, $190 \mathrm{n} .79$; 1984, 1:248-9 n.1, 2. Testard's view of De off. min. 1.116 contributes importantly to his overall opinion of the work as incoherent and to his belief that Ambrose recognized "le débacle de sa composition" $(1974,191)$ but was incapable of repairing it. Testard's later study shows that he has not changed his mind (1989, 73 n.26, 93 n.85). 
He believes Ambrose is stating, clearly and unapologetically, his intent to ground his moral treatise in scriptural exempla, rather than to use them only as illustrations of previously derived theoretical concepts. ${ }^{37}$

This difference in viewpoint is striking. It has become a commonplace of commentary on De officiis ministrorum, and one that Testard clearly accepts but uses in a derogatory sense, to say that Ambrose has simply substituted examples gleaned from scripture for cicero's examples drawn from Roman history, while retaining, more or less successfully, basically ciceronian structures and concepts. ${ }^{38}$ Steidle's opinion, however, is otherwise; he believes that Ambrose has deliberately made the exempla primary. ${ }^{39}$ Although steidle does not take his point further, it follows that such a method, if it has been correctly understood, would comport well with Ambrose's

37 Steidle 1984, 20-1, 42, and 58 n.17: " . . gerade das, was Testard und andere moderne Autoren ihm vorwerfen, ist also nach Ambrosius der Vorzug seiner Gestaltungsweise."

38 Testard 1984, 1:31-3. Testard says also that he does not want to go so far as to say, with Hiltbrunner (1964), that classical culture forms only a facade for Ambrose, behind which everything is new (1984, 1:11-2 n.1). This is the only instance in which Testard seems to step back from full acceptance of the prevailing "framework" metaphor used to describe the relation of Ambrose's work to Cicero's.

39 Steidle refers not only to De off. min. 1.116 to support his argument, but to the at least equally significant closing passage of the work, 3.138, "wo er als wesentlichen Inhalt seiner schrift die copia multorum exemplorum bezeichnet" (1984, 20). 
repeated assertion of the priority of scripture to all philosophy. I shall return to this point as Ambrose's views of Christian wisdom and of philosophy are unfolded in the chapters to follow.

Researchers who have looked at Ambrose's works as wholes rather than in fragments, and who have studied them less in contrast to Augustine's thought than with an appreciation of Augustine's intellectual respect for Ambrose, generally describe Ambrose's literary and pedagogical efforts in terms that Testard and Madec likely would eschew. Savon, Courcelle, and Nauroy all refer to Ambrose as a rigorous thinker who exercised great care in introducing and modifying non-Christian material within his sermons and essays. One of Savon's primary themes, in his book about the influence of Philo on the bishop's exegeses, is Ambrose's consistent ability in constructing the "Philonian" treatises to take what was useful and suitable in Philo, and to eliminate or change what did not fit his beliefs or purposes $(1977 \mathrm{~b}, 1: 7-9,90,235,382)$. Similarly, Courcelle shows Ambrose's thoughtful interpolation of Plotinian ideas insofar as they gave mellifluous and accessible expression to what he considered to be true Christian doctrine (1962; 1963, 165$6 ; 1968,93-138,311-82 ; 1976,172-5)$. Nauroy $(1974 ;$ also 1985b, 373-4, 384) presents a convincing description of the composition of De Jacob that shows Ambrose 
scrupulously interweaving Plotinus, Philo, and Paul with both the stoic philosophy and the exemplary Hebrew martyr story of 4 Maccabees.

In the tradition of these latter scholars and in response to Madec, it is my purpose in this dissertation to demonstrate, from a consideration of Ambrose's writings as a whole, his quite coherent and consistent understanding of Christian wisdom and, in close conjunction, of philosophy and its dangers. In doing so, I shall show that Ambrose's apparent tacit acceptance of philosophical ideas and reasoning processes, in the face of his adamant opposition to "philosophy," is not paradoxical at all -- and, therefore, need not be reasoned away -- but is, in fact, quite comprehensible given his conception of wisdom and its pursuit.

My own repeated readings of Ambrose's works lead me to agree with Madec that there is no significant change in his themes, interests, beliefs, or style over the 22 years of published materials. My approach, then, will be to analyze Ambrose's view of various topics relevant to philosophy, wisdom, and the use of reason as expressed throughout his works, generally without regard to chronology. This approach requires that I grasp as wholes the extended discussions that include Ambrose's reflections on those subjects in order to preserve both the context and the contextual meaning of his statements. 
The brief excerpts I shall use to support my claims about Ambrose's thought can then be regarded as representative of or compatible with the larger messages from which they have been extracted. I am explicitly seeking a synthesis of thought from this careful but relatively unsystematic preacher, and I believe his consistency of thought and his single-minded emphasis on a limited number of themes make such a synthesis possible.

To begin with, I shall explore Ambrose's understanding of the importance and uses of human reason, this being the area that shows most clearly his deeply rooted position within the heart of the philosophical milieu of his time. All the scholars cited above, whatever their opinion of Ambrose's abilities, have agreed that he is an assiduous user (or "borrower") of philosophical terms and ideas -- hence, the concern about paradox. However, the display of his statements about the role of reason in chapter two should make clear that it is not accurate -- perhaps not even conceivable -- to portray Ambrose as one who stands apart from his philosophical environment but dips into it from time to time for useful expressions and metaphors which he can then bend to his exegetical will. This is the portrait implied by the 
metaphor of "borrowing" and the one on which Madec trades for his theory of verba-res dissociation. ${ }^{40}$

Rather, Ambrose speaks and, I warrant, thinks in the terms of that philosophical milieu because it is his milieu and he stands firmly within it, by virtue of his education, his reading, his continued interests, his circle of acquaintances and friends, and his rhetorical and literary pursuits. From his classical schooling and his place in Roman society through his career within the intellectual circles of Milan, it cannot be said that Ambrose is outside that mixed philosophical tradition of the fourth century C.E. which reflected the intermingling of Stoic and Platonic cosmologies and ethics. Ambrose does not "borrow" the philosophical terms and expressions he uses. They are his by birthright; they are the way he thinks.

It is equally true that christianity, the traditions of scripture, and the teachings of the church are his. Thus, as we shall see in the third chapter, he ties those starkly philosophical statements about reason to what he

40 This is also the inter-tradition practice of borrowing that Macintyre (1988, 349-403) puts forward as the primary means by which discrete intellectual and cultural traditions solve their inevitable epistemological crises. My analysis of Ambrose's situation will show -- by example, Ambrose's favored method -- the extent to which the intermingling of traditions in the life of a person (even an official of a tradition as, by MacIntyre's definition, Ambrose was) makes it difficult for MacIntyre's abstract construct to explain the actual interaction of different traditions of reasoning in practice. 
firmly believes to be their christian source and fulfillment, showing their dependence on God and on faith for their origin, enactment, and completion. The links he forges between philosophical tenets and Christian faith clarify his adamant opposition to philosophy in general as a false discipline that has severed its vital connection with its root in scripture and, ultimately, in God, and that has also thereby lost any chance of achieving a valid end.

The unity and tenacious focus of Ambrose's thought that shed this light on his understanding of philosophy and its errors also reveal Ambrose's vision of Christian wisdom, the only true philosophy, the only acceptable way of life. Chapter four will present Christian wisdom -its source, nature, and end -- as understood by Ambrose.

The next chapter will then explore his rhetorical use of and pedagogical reliance upon scriptural exempla. Ambrose's conception of wisdom and his conviction of the absolute truth and priority of scripture explain the foundational and pivotal role of biblical exempla in his teachings. Steidle is correct: the exempla are primary; all else -- all the cognitive content of Christian wisdom and, therefore, of Christian ethics -- follows from them. In the introduction to saint Ambroise et la philosophie, Madec claims, but does not seem to retain, a "favorable presumption" for his study: that Ambrose is 
both less slavish as a borrower from philosophy and less absolute in his condemnation of it than his critics claim. ${ }^{41}$ This dissertation will show that presumption to be correct and capable of elaboration.

41 Madec 1974c, 17: "Mais on peut présumer que semblables qualificatifs sont probablement excessifs, et que l'esprit d'Ambroise comportait moins de servilité dans la pratique de l'emprunt et moins d'arbitraire dans la condamnation de la philosophie. Ce préjugé favorable nous semble en tout cas préférable dans l'étude que nous voulons entreprendre." 


\author{
CHAPTER TWO \\ THE ROLE OF REASON \\ Ambrose as Philosopher
}

\title{
1. The status of reason
}

For Ambrose, man of the fourth century, educated to profess law within the imperial court, it is reason, ratio, mens, that defines the human animal." "The human being is the mind, which is capable of reason, for a human is defined as a living, mortal, rational animal." ${ }^{2}$ In Expositio psalmi CXVIII, Ambrose again identifies homo by the capacity for reason (2.13) and then, later in the same commentary, declares the criterion for bearing the name of human being to be "the enduring vigor of the soul, the faculty of reason capable of understanding and judgment. ${ }^{3}$

1 Although Ambrose may occasionally speak of the mens exercising ratio, it is clear that for him there is no part or function of the mens (unlike the anima, as we shall see) that cannot also be called ratio; the terms are virtually interchangeable in his writings. Earlier controversies within stoicism concerning whether the hegemonikon (DL 7.159), the governing part of the soul equated with the mind or reason by Latin writers (see n.8), is entirely rational or includes the non-rational (Long 1986, 175-7) do not seem to be Ambrose's concern.

2 De Noe 10 (CSEL 32.1, 420.3-5): "Sensu autem altiore illud manifestatur quia homo mens est, quae est rationis capax; homo enim definitur animal vivum mortale rationabile."

3 Exp.ps. 118 10.11 (CSEL 62, 209.16-8): "uiuacis animae uigor, sensus rationis et intellectus capax atque iudicii, ut digna domus tanto habitatore uideatur, non 
It is, moreover, this capacity for reason which distinguishes human beings from the other animals. "There is nothing by which a human is superior to the rest of the animals so much as by the fact that he or she is a participant in reason." 4 Not surprisingly, the defining, distinguishing mind is unequivocally considered to be every person's outstanding attribute, the most precious of the creator's gifts (De off. min. 1.49, 252; De Noe 8 ).$^{5}$

Ambrose often uses the argument that rationality separates humans from beasts to enhance his moral exhortations (see, for example, De interpell. 3.26), but its appropriation in De officiis ministrorum (1.124, see n.4) for purposes of definition correlates with similar use in Ambrose's model for this work, Cicero's De officiis (1.4.11). The identification of the human being as a particeps rationis is also taken from that paragraph in Cicero and has strong philosophical echoes. There are two associated ideas common to later stoicism, especially in

amittat suae praerogatiuam naturae, ne hominis nomen amittat."

The description of homo as capax rationis is mentioned several other times in Ambrose's writings, for example De interpel1. 3.26, Exam. 6.75, and De Noe 9 .

4 De off. min. 1.124 (PL 16, 60A): "Nihil est enim quo magis homo caeteris animantibus praestet, quam quod rationis est particeps . . ."

5 It should be noted that Ambrose does not believe human beings to be the only rational creatures, just the only rational ones among the earthly, visible beings; angels and archangels are also capable of reason (De fide 5.32). 
its confluence with Platonism: first, that the human mind, or hegemonikon (and not the entire soul, as was claimed in early stoic thought), is a part of the divine, is in fact the "god within" (Rist 1969, 264-72); and, second, that reason is the one faculty held in common by god and human beings (Long 1986, 165; Dillon 1977, 80; Dihle 1982, 2-3). Both ideas find expression, and availability to Christian thought, in the language of pneuma-logos, the mediator of the identity of divine and human reason for philosophy and the personified bearer of the divine image, according to which the human mind is formed, for Christian theology. ${ }^{6}$ Although Ambrose does not elsewhere speak of the person specifically as a "participant" in reason, the close identification of the human mind with God, both as an internal presence and as the model of whom reason is the image, is a theme pervading his works.

The first man was given the task of naming the other living beings at least in part to teach him and successive generations that the human mind is not only different from but superior to all other creatures: "God called all things to you that you might know your mind to be above

${ }^{6}$ Spanneut 1973, 23-31, 37, 134, 146. That the logos of Stoicism and later Platonism is closely related to the Logos of Christian theology is unquestionable, but spanneut appropriately reminds his readers of the nonetheless marked distinction between them $(1973,134)$ : "Entre le logos stoïcien et celui de saint Jean, s'étend l'abîme de la Création, de l'Incarnation et de la Rédemption." 
them all." This primacy of human reason is true also in relation to the other faculties of the person: the mind is the principale, the most important and controlling part of the soul (De bon. mort. 44 , De Noe 38). 8 Just as gold is chief among metals, so the good mind is superior to the rest of the human being (De Abr. 2.20).

In his treatise on Cain and Abel (2.34), Ambrose borrows from the psychology of the old stoa (DL 7.110) to describe the soul as composed of eight parts: reason, the five bodily senses, and the powers of speech and reproduction. Reason is the power which dominates the other seven, and must do so lest they all perish.

The eight-part schema is used in this particular context for exegetical purposes in explicating the moral meaning of the number seven in God's promise that anyone who killed cain would be subject to seven-fold vengeance (Gen. 4.15). Ambrose's only other reference to this portion of old stoic thought comes in another fugue on the

7 De par. 52 (CSEL 32.1, 309.6-7): "uocauit ad te omnia deus, ut supra omnia mentem tuam esse cognosceres." For Ambrose's reliance on Philo in this passage, see Savon $(1977 \mathrm{~b}, 1: 40-1)$.

8 Principale and principatum are recognized as translations of the Greek hegemonikon in the oxford Latin Dictionary. An example of this use of principale is in Seneca Epistulae morales 113.23, 121.10, and 92.1, where the faculty includes rational and irrational parts, consonant with later stoicism. Principatum is used by cicero in De natura deorum 2.11.29, where it is explicitly equated with hegemonikon and with mens, and in Tusculanarum disputationum 1.10 .20 , where, in a reference to Plato, it is defined as ratio. 
number seven (De Noe 40, reflecting on Gen. 7.2), and in both instances he is following as his model the works of Philo, who also uses the eight-part soul when "he is in the process of extolling the hebdomad, and a group of seven dependent on a monad is what he wants" (Dillon 1977, $174)$

Savon $(1977 \mathrm{~b}, 1: 90)$ remarks on the passage from De Cain et Abel to make two points. First, Ambrose takes notable care not to lose any detail from the literary riches of his model (Philo) as long as it does not seem to be dangerously wrong or heretical. Second, he has obviously judged such philosophical formulations as that of the eight-part soul to be harmless enough to use them as decorations, like flowers of rhetoric, to add a certain luster to his discourse, but always follows them, as he does in this instance, with a rapid return to properly biblical symbolism.?

Savon is undoubtedly correct, but his remarks can be taken a bit further. In these brief allegorical passages,

9 Savon 1977b, 1:90: "Une fois encore, on surprend chez Ambroise ce souci de ne rien perdre, ce goût de la copia qui lui fait emprunter à son modele tout ce qui ne semble point favoriser quelque erreur dangereuse et actuelle comme l'arianisme.

- . Sans doute les juge-t-il assez anodines pour les employer comme des ornements qui donnent un certain lustre à son discours, comme des fleurs de rhétorique, un peu desséchées, il faut bien de dire. Un 'melius', un 'plurimum refert' marquent bien vite le retour aux choses sérieuses, c'est-à-dire au symbolisme proprement biblique -- le repos du septième jour -- ou à la lettre même de la Genèse." 
Ambrose is clearly not interested in teaching his hearers or readers the details of stoic psychology. Even if he were, by the fourth century this doctrine had been generally superseded by a blending of later stoic and Platonic ideas into the more prevalent notion of a twopart (rational and irrational) soul, with occasional philosophical excursions into the traditionally platonic tripartite soul (Rist 1969, 180-2; Long 1986, 171, 213, 219; Dillon 1977, 101-2, 174-5). Indeed, when Ambrose does make a point about psychology in his writings, he usually refers to the soul as bipartite (for example, De Abr. $1.4,2.2$; De off. min. 1.227 ; see Madec $1974 \mathrm{C}, 238-$ 9).

The significance of the De Cain et Abel and De Noe passages, therefore, is not that they are somehow revelatory of Ambrose's pedagogical aims or psychological theory. Rather -- to follow Savon in giving Ambrose credit for being a careful, thoughtful expositor -materially they add to the long list of statements exemplifying Ambrose's belief in the essential dominance of reason over the irrational within the person, an idea met repeatedly and under various guises in his works. Formally they show that Ambrose is not always required to reject an explicitly philosophical schema as such nor compelled to find a useful philosophical formula's source and justification in biblical writings. 
That the eight-part soul theory is known to be of stoic provenance and that it has no reasonable connection to biblical teachings are not adequate reasons for Ambrose to consider it either wrong or too dangerous to use. It is not just that the old stoa's doctrine is harmless and available as rhetorical embellishment, but that its use shows Ambrose to be less the adamant, reactive combatant against philosophy than Madec, for one, portrays ${ }^{10}$ and more a thinker with the freedom to use selected fruits of philosophy, within firm limits -- a freedom allowed by Ambrose's conviction that those fruits can only be the result of philosophy's original, though unacknowledged, source within scripture.

\section{Vigor mentis}

Throughout his works, Ambrose consistently stresses the crucial role of reason, of the human mind, in defining that which can be called human and in enabling human beings to envision and strive for the blessed life, the life which exists only among those living a perfect life "according to reason's judgments and the mind's vital energy. "11

10 Madec does not comment in his book on either De Cain 2.34 or De Noe 40, despite their obvious philosophical connection.

11 De Jacob 1.29 (CSEL 32.2, 22.17-20): "est ergo beata uita in hominibus, sed in his scilicet, in quibus fuerit perfecta uita. perfecta autem uita non sensibilis ista, sed 
The "vital energy" of the mind, or vigor mentis in Ambrose's usual phrase, is a recurring theme in his writings, encapsulating his understanding of reason as the active, defining, organizing, dominating, aspiring power in a well-ordered human life. "For in what do we consist? In the substance of the soul and the vigor of the mind." 12 It is by the potency of the mind, along with purity of soul and chastity of body, that a person can be considered to have been created in the image and likeness of God and, by that same energy, can perceive the divine image in others (Exam. 3.31, 6.45).

Governance of the soul, the flesh, and external things is the task of the mind's vital force (Exam. 6.39, Ep. 43.16). Ambrose succinctly reveals the extent of the dominance he attributes to vigor mentis when, in his treatise on Noah, he states that the mind's power in the soul is like that of the pater familias in his own home (De Noe 38). Noah, the father and patriarch, is an exemplar of justice because of his inclusion of all species of animals in the ark but, in the deeper sense, his custodial justice is a marker for us of the moral work of a vigor mentis that must constrain all varieties of irrational passions to submit to the governance of the

illa rationabilis secundum tractationem rationis et mentis uiuacitatem."

12 Exh. virg. 68 (PL 16, 356C): "In quo enim sumus? In animae substantia et mentis vigore." 
mind. Without such rational restraint, which is the true remedy for Noah's flood, one risks certain inundation by the allurements of physical pleasure (De Noe 30, cf. De Isaac 2). 13

Vigor mentis is prescient, studious, and manifest especially in the "theoretical arts" (De off. min. 1.188, De fuga 10, Exam. 1.17). Not only does Ambrose identify this force as the means by which one attempts the heights of knowledge, but he suggests that it may also be capable of effecting the final ascent of reason to the presence of God: Jacob, for one, could leave the hovel that was his body and enter into paradise when he wished by the power of his mind. ${ }^{14}$

The tasks of reason include both control of irrational forces and things, and intellectual and moral aspiration and ascent; these are accomplished by the vigor of the mind, the rational part of the soul. Before discussing in detail these two crucial roles of reason -the restraint of passion and the attempt to ascend -- and

13 Vigor mentis is itself vulnerable to being weakened, even to the point of uselessness, by the luxuries of the world (De Noe 49), by sexual intercourse (De Isaac 2), and even by sleep (Exp. ps. 118 7.31).

14 De Jacob 2.38 (CSEL 32.2, 55.23-4): ". . . cui liceret, cum uellet, corporeo isto exire gurgustio et superna paradisi mentis uigore penetrare . . ."

Moreover, it is by the vigor of one's mind that one can be caught up into the various levels of heaven, as was the person reported by Paul (2 Cor. 12.2-4) and alluded to by Ambrose in De paradiso 53 . 
the essential contribution of repeated effort to the accomplishment of those roles, it will be helpful to look at Ambrose's more general statements describing the work of reason in human life.

\section{What reason does}

Ambrose's interest in reason, as revealed in his sermons and essays, is primarily in regard to its role as governor of the moral life, hence the emphasis on control of the passions and on the process of perfection. The question remains whether Ambrose attributes to reason any significant degree of activity that can be called purely intellectual. The answer to that would seem to be affirmative, but with the qualifier that he is not very interested in the speculative function as such and, furthermore, that he sees potential danger there, the danger of being led by intellectual preoccupations either toward vain philosophical conjecture or away from proper moral activity, or both.

Following the paragraph from De officiis ministrorum referred to earlier $(1.124 ;$ see $\mathrm{n.4})$, in which Ambrose uses participation in reason to distinguish humans from animals, he continues to follow Cicero (De off. 1.6.18-9) in describing the intellectual nature of human beings:

It is characteristic of all persons to seek after truth, in accordance with human nature which draws us to an eagerness for learning and knowledge and fills us with the desire for inquiry. To excel in 
this seems a very good thing to everyone, but is achieved by only a few, who expend extraordinary effort in turning over their thoughts and considering their judgments, so that they are able to attain that blessed and virtuous 1 ife and approach it in their works.

The addition of "works" to what began as a description of the speculative activity of the mind heralds the turn of the passage away from the ciceronian model and towards its moral climax: Ambrose cites scripture (Mt. 7.21: "For not everyone who says to me, 'Lord, Lord,' shall enter into the kingdom of heaven, but the one who does what I say") and then exclaims that he cannot imagine what such a devotion to knowledge might involve in the absence of resultant deeds. 15

Madec (1974c, 237-9) cites these paragraphs to support his point that Ambrose looks at reason (and

15

De off. min. 1.125 (PL 16, 60B): "Omnibus igitur hominibus inest secundum naturam humanam verum investigare, quae nos ad studium cognitionis et scientiae trahit, et inquirendi infundit cupiditatem. In quo excellere universis pulchrum videtur, sed paucorum est assequi: qui volvendo cogitationes, consilia examinando, non mediocrem impendunt laborem; ut ad illud beate honesteque vivendum pervenire possint, atque operibus appropinquare. 'Non enim qui dixerit,' inquit, 'mihi: Domine, Domine, intrabit in regnum coelorum, sed qui fecerit ea quae dico.' Nam studia scientiae sine factis, haud scio an etiam involvant magis." Thamin's comment $(1895,253)$ about the preceding paragraph (1.124) is equally true of this one: "le commencement en est d'un stoïcien, et la fin d'un chrétien." Although Cicero also emphasizes the importance of moral action in De officiis 1.6 .19 (". . . cuius studio a rebus gerendis abduci contra officium est. Virtutis enim laus omnis in actione consistit. . ."), he immediately returns to the subject of the goodness of mental activity and makes no statement resembling Ambrose's final insistent sentence. (See also Testard 1984, 1:250 n.10.) 
wisdom, Madec will ultimately argue) generally from the moral/ascetic point of view and has little to say about its cognitive function. ${ }^{16}$ Madec knows of only a few other texts in which Ambrose refers to a speculative role for reason but adds the disclaimer that he has not made a systematic investigation of Ambrose's use of the word ratio $(1974 \mathrm{C}, 239 \mathrm{n.298})$. Of the three passages offered by Madec, only one seems to fit the category: in De spiritu sancto 2.126 , Ambrose constructs an argument from analogy to explain the nature and role of the Holy spirit by evoking the human rational faculty, which not only excels the other powers of the soul but also is particularly capable of comprehending the nature of human beings. The other two citations (De Isaac 22 and De fide 5.32) merely repeat the definition of the human as rational without delineating the activity of reason, speculative or otherwise.

There are, in fact, several places in Ambrose's writings, unmarked by Madec, where Ambrose clearly acknowledges the importance and worth of reason's

${ }^{16}$ Madec 1974C, 239: "Il nous suffit de constater que le rôle de la raison est régulièrement envisagé par lui du point de vue moral et ascétique, tandis qu'il ne fait que très peu d'allusions à la fonction cognitive de la raison." This interpretation is offered more bluntly by Holte $(1962,304-5)$, in outlining the difference between Ambrose's and Augustine's understanding and use of the terms auctoritas and ratio: "Ambroise n'introduit pas dans la ratio l'idée d'une spéculation philosophico-dialectique, pas même sur le fondement de la foi." 
cognitive activities; in each instance, however, Ambrose immediately proceeds either to a warning against heretical or philosophical diversions or to moral exhortation. In Exameron 6.67 , in the midst of his praise of the human body, Ambrose distinguishes human senses from those of non-rational beings by the human ability to interpret what is perceived sensually. "Only the human being, among all earthly creatures, gathers the secrets of wisdom by listening and reflection and good sense." But what one hears must be what God says (Ps. 85.8); to seek cosmic knowledge rather than divine wisdom is not acceptable. ${ }^{17}$ Elsewhere Ambrose says that catechumens are capable, given proper guidance, of using their own reasoning ability to find the truth in scripture by careful examination and logical thought; but his main point is that the inevitable result of correctly exercised reason is the rejection of Arian heresies (De par. 58).

17 Exam. 6.67 (CSEL 32.1, 255.1-4, 11-4, 18-256.4): "erigit et bucula ad caelum oculos, sed quid spectet ignorat, erigunt ferae, erigunt aues, omnibus est liber aspectus, sed soli inest homini eorum quae aspiciat affectus interpres. . . . secreta sapientiae solus homo ex omnibus generibus quae in terris sunt auditu et meditatione et prudentia colligit, qui potest dicere: 'audiam quid loquetur in me dominus deus.' . . . sibi habeant prudentiam suam qui radio caeli spatia terrarumque describunt, sibi habeant intellectum suum, de quo dicit dominus: 'et intellectum prudentium reprobabo.' neque numeros orationis ac modos et modulos musicae sapientiae hoc constituam loco, sed eam sapientiam definio, de qua dicit propheta: 'incerta et occulta sapientiae tuae manifestati mihi.'"

The translation and epistemological significance of auditu, meditatione, and prudentia are discussed in chapter four. 
Human beings have been given "the faculty by which you may know all things in the world and form judgments about what you know," but concomitant human weakness resulted in the misjudgments that made expulsion from Eden necessary. ${ }^{18}$ The wise are distinguished from the foolish by their ability to reflect on the past and contemplate the future, but the importance of these intellectual skills lies in their contribution to virtuous behavior (De Noe 117-8).

Finally, only in a letter to the priest Horontianus, answering his correspondent's question about the lofty status given to humanity, the crown of creation, in the Exameron, does Ambrose speak in unrestrained fashion about the purely intellectual glories of the human mind: ${ }^{19}$

Human beings came forth last of all creatures, pleasing in appearance, exalted in mind, so that

18 De par. 52 (CSEL 32.1, 309.8-12): "dedit tibi certe sensum, quo uniuersa cognosceres et de cognitis iudicares, meritoque de illo fecundo paradisi agro eiectus es, quia non potuisti seruare mandatum. sciebat enim deus esse te fragilem, sciebat iudicare non posse. . ."

19 Ep. 43.14-5 (L 16, 1133B-4A): "Processit tamen postremus creaturarum omnium homo, specie gratus, mente sublimis; ut omni esset creaturae miraculo. In quo ad similitudinem aeterni Dei nous esset invisibilis, humana specie amictus. Hic est nous animae vigor, principatum animae et corporis sibi quasi rector vindicans. . . ita nous hominis videt omnia et non videtur, habens sui invisibilem substantiam, disciplinis et consiliis ac sensibus comprehendit latentia, penetrat occulta maris atque omnium diffusa terrarum latibula . . . elevans quoque se in aerem et ejus nubilosa praetergrediens, ad coeli alta se dirigit studio cognitionis, et ardore sapientiae . . . majore se cupiditate attollit ad ipsum gremium Patris, in quo est unigenitus Dei Filius enarrans secreta Dei . . ." 
they would be a marvel to every creature. In them the invisible nous, clothed in human form, would be according to the likeness of the eternal God. This nous is the power of the soul and claims for

itself, like a ruler, the governance of soul and body. . . Thus the human nous sees all things and is not itself seen, having its own invisible substance. By learning and judgment and perception, it understands things that are hidden, penetrates the secret places of the sea and the scattered hiding-places of all the earth . . . Lifting itself into the air and going beyond its clouds, the nous directs itself to the heights of the heavens by its eagerness for knowledge and its passion for wisdom . . . By greater desire it raises itself to the very bosom of the Father, where the only-begotten Son of God is interpreting God's mysteries. .

As always for Ambrose, the ultimate end of the mind's yearning flight toward wisdom is christ, in "the very bosom of the Father."

The opening chapters of De Jacob et vita beata, which follow closely the fourth book of Maccabees, ${ }^{20}$ comprise the densest collection of Ambrose's thoughts on the role of reason and confirm the impression that his concern is with reason's moral governance. Ambrose establishes his theme in the first lines of the work: "the mind focused on reason goes in advance of the virtues and restrains the passions." Where admonitory words may fail, contemplation of right reason can persuade human free will to obedient,

20 Nauroy (1974) correlates De Jacob with its sources in 4 Maccabees, Romans, and the works of Philo and Plotinus. The beginning and end of the work (1.1-8 and 2.43-58) are clearly drawn from the strikingly philosophical (primarily stoic but with many Platonic and Aristotelian overtones) book of 4 Maccabees. (See also Nauroy 1990/1, and Schenkl's introduction to CSEL 32.1, xiii-xvi.) 
moral action. Right reason tames and constrains passions so that the inevitable perturbations of the soul may not dominate the person. ${ }^{21}$

As Madec says $(1974 \mathrm{C}, 239 \mathrm{n} .297)$, the first passages of De Jacob constitute a sort of treatise on moral reason, but more precisely they form Ambrose's only discussion of "right reason." Recta ratio or orthos logos was for the old stoa (DL 7.88) the reason which the human being potentially holds in common with god (for Chrysippus, right reason is Zeus); that is, it is normative divine reason. Human beings follow right reason insofar as their thoughts and actions accord with divine reason, as their logos exhibits the correct tonos. ${ }^{22}$ Right reason is a moral term, designating reason concerned not with

21 De Jacob 1.1 (CSEL $32.2,3.3-4,7-4.1)$ : ". . mens rationi intenta praecurrit uirtutibus, passiones coercet . - sed quia nudus sermo ad monendum utilis, ad persuadendum infirmus est, ideo adhibenda est rationis rectae consideratio, ut quod sermo bonus praescripserit ratio plenius tractata persuadeat. non enim seruili ad oboediendum constringimur necessitate, sed uoluntate arbitra, siue ad uirtutem propendimus siue ad culpam inclinamur. et ideo nos aut liber affectus ad errorem trahit aut uoluntas reuocat rationem secuta. passio autem grauissima culpae concupiscentia, quam ratio emollit et conprimit. emollire enim potest, eradicare non potest, quoniam animus qui est rationis capax suarum passionum non dominus, sed repressor."

22 Ambrose is not a stranger to this defining element of Stoic physics; in at least two instances (De Noe 82, Exam. 1.23), he warns of the inevitable death and dissolution of bodies in which simple, rational, natural motion has become confounded and diverse, that is, when the tensional motion of the pneuma is irrational, the tonos distorted (see Rist 1969, 86-95). 
cosmological speculations but with knowing what to do and doing it, so that one's life is in harmony with the divine and with nature (Inwood 1985, 109, 155-73; Long 1986, 1758).

In later Stoicism and in Middle Platonism, orthos logos continued to designate the reason common to humans and god but the emphasis was more on its equivalence to the divine law of nature, informing people what is to be done and what is prohibited (Spanneut 1973, 118; Dillon $1977,80)$. Philo spoke in this way of right reason, also recognizing it as the law of nature and of human conduct, and even at times equating orthos logos with virtue (Spanneut 1973, 120-2).

Ambrose fashioned his treatise about paradise on Philo's writings, but at the one point in the model where Philo speaks of right reason, Ambrose demurs. The general subject is the rivers that flow in Eden; the point of divergence concerns the significance of God's placement of Eden in the East (Gen. 2.8-14). Both authors speak of the rising sun but for Philo that sun is right reason while for Ambrose it is Christ (De par. 23). Ambrose's need to correct his model appears to arise from Philo's making of orthos logos the very source of all the virtues represented by the rivers of paradise, a role Ambrose attributes to the Christian Logos (Savon 1977b, 1:239). 
De Jacob, on the other hand, is a work that reveals only occasional philonian influences (Savon 1977b, 1:13, 2:14 n.33) and, as Nauroy (1974) has shown, those influences are manifested in parts of the treatise (specifically 2.1-42) dealing with subjects other than right reason; Ambrose's use of recta ratio here cannot be directly attributed to his reading of Philo. ${ }^{23}$ Moreover, although he clearly follows the early chapters of 4 Maccabees in the first eight paragraphs of De Jacob, the Greek text (Septuagint) of the apocryphal book speaks of logismos often but not of orthos logos. Rather, Ambrose translates the Greek term for his own purposes: "This is, therefore, right reason's direction, which the Greeks call logismos. 124

Holte (1962, 173 n.4) claims that Ambrose here changes the meaning of logismos, but that he could not have been entirely aware that he was doing so, because the statement in De Jacob 1.6 implies that Ambrose is giving what he believes to be a literal translation. It is Holte's assertion that, while in Plotinus's thought the Greek word connoted the faculty of dialectical reasoning, here Ambrose instead gives it a thoroughly ethical sense,

23 As Nauroy says (1974, $119 \mathrm{n} .17)$, Ambrose's familiarity with the concept owes at least as much to his readings in Cicero and Seneca as to those in Philo.

24 De Jacob 1.6 ( CSEL $32.2,8.5-6)$ : "haec est igitur rectae rationis tractatio, quam Graeci logismon nuncupant" 
a sense, moreover, that is tied inextricably to knowledge of scripture. In showing how Ambrose alters plotinus, Holte, apparently relying upon other, uncited writings by Ambrose, connects Ambrose's statements about right reason with his reliance on scripture and, specifically, on allegorical interpretation. Holte thereby concludes that, for Ambrose, the perfect life of reason is a christian ethos based on the study of the Bible. ${ }^{25}$ In the same vein, Holte asserts that Ambrose is implicitly ascribing persuasive moral power to the deeper sense of scripture when he explicitly attributes that power to right reason in the first paragraph of De Jacob, as though recta ratio could be defined there as the allegorical interpretation of scripture. While, in general, Holte's understanding of Ambrose's overriding interests is correct, his arguments in this instance seem too deeply rooted in his larger thesis -- that Ambrose's antipathy to philosophy and his single-minded biblicism disqualify him as a major influence on Augustine's theological formulations -- and they cannot be supported from the text of De Jacob. On the other hand, Nauroy (1974), in a statement consistent with his convincing elucidation of the various influences on De Jacob, believes Ambrose's equation of

25 Holte 1962, 173: "Si donc pour Plotin la perfection de la vie raisonnable consiste dans l'exercice autonome de la spéculation philosophico-dialectique, pour Ambroise au contraire, elle est un ethos chrétien fondé sur l'étude des Saintes Lettres." 
logismos with tractatio rectae rationis to be faithful to the use of the Greek term in 4 Maccabees. Logismos is the application of orthos logos to the domain of knowledge and practical ethics; such is also the sense of rectae rationis tractatio. ${ }^{26}$ It would appear, over against Holte's assertion, that Ambrose's use of the primarily stoic concept recta ratio is an important example of his acceptance of certain pagan philosophical terms and ideas, evidenced by his ability freely to use such terms, which can retain their original meaning while being embodied by scriptural exemplars (Nauroy 1974, 118) -- in this instance, by David, Joseph, and Jacob -- a practice which Ambrose uses again and more extensively in De officiis ministrorum.

Ambrose's summary statements about recta ratio reflect the term's original and evolved philosophical

${ }^{26}$ Nauroy 1974, 119 n.17: "Quant au concept éminemment stoïcien de 'recta ratio' . . En verité, Ambroise donne à 'recta ratio' dans [De Jacob], et plus exactement à 'rectae rationis tractatio' . . . un sens qui dérive directement du sens que IV Macc. donne à logismos . . Le logismos est l'application de l'orthos logos au domaine de la connaissance et de la morale pratique: tel est aussi le sens de 'rectae rationis tractatio,' où 'tractatio' marque bien qu'il s'agit pour l'esprit sobre ('mens sobria') d'apprendre à 'manier,' à exercer la droite raison, afin de déterminer la volonté libre ('voluntate arbitra') à choisir la vertu." 
definitions as the reason common to god and humans and as

the divinely ordered natural $1 \mathrm{aw}:^{27}$

Therefore, the self-controlled mind is able to curb and control attacks of the passions, however severe, to cool all the vehemence of the most ardent desire, to turn the emotions into other channels, and, by right reason's direction, to spurn the passions. For when God created human beings and implanted in them moral sense and feelings, God then established the royal rule of the mind over the emotions so that all human feelings and emotions would be governed by the mind's strength and power. To add to the beauty of this creation, God shaped the human mind itself with divine precepts and equipped it with the teachings of wisdom, so that the person would know the things to guard against and would recognize the things to choose. Therefore, the mind which, by right reason, holds to the teachings of wisdom, so that it may know divine and human things, is educated in the law through which it learns which passions it must submit to itself.

Following his model (4 Macc. 2.1-3), Ambrose presents the patriarch Joseph as an example of right reason, before and after recounting Joseph's rational justification of

27 De Jacob 1.4 ( CSEL 32.2, 6.5-17): "potest igitur mens sobria inpressiones refrenare ac reprimere quamuis grauium passionum et feruorem omnem cupiditatis flagrantissimae refrigerare, deriuare alio motus et rectae rationis tractatione despuere passiones. etenim cum deus hominem constitueret et in eo mores sensusque plantaret, tunc motibus eius regale inposuit mentis imperium, ut omnes sensus motusque hominis eius uigore ac potestate regerentur. adiuncxit ad gratiam creaturae, ut mentem ipsam diuinis informaret praeceptis et sapientiae instrueret disciplinis, quibus et cauenda nosceret et eligenda cognosceret. mens igitur recta ratione tenens disciplinam sapientiae, ut diuina et humana cognoscat, eruditur in lege, per quam discit quas sibi subicere debeat passiones." 
his refusal to submit to the allurements of his master's wife: ${ }^{28}$

Starting from temperance, Joseph subdued the heat of his youth and, by right reason's guidance, strengthened his soul, which was tempted by the allurements of adultery. . . . This is, therefore, right reason's direction, which the Greeks call logismos, by which the mind focused on wisdom is strengthened.

Here are exemplified three crucial elements of Ambrose's idea of recta ratio and, as seems clear from the body of his writings, his view of reason in general: it acts for moral purposes, it is made stronger by exercise, and its primary goal is wisdom. These three notions undergird and accompany Ambrose's prominent themes of restraint, striving, and ascent.

a) Restraint of passion

In regard to its moral ends, reason determines what actions may be congruent with virtue (De off. min. 1.98, Ep. 67.5). Thought is required, prior to action, so that one may know both what ought to be done and how it should be accomplished (Exp.ps. 118 8.32). In general, ${ }^{29}$

28 De Jacob 1.6 (CSEL $32.2,7.18-20,8.5-7):$ "ab hac [temperantia] profectus Ioseph et calorem iuuentutis edomuit et temptatum adulterinis animum inlecebris rectae rationis inductione firmauit. . . . haec est igitur rectae rationis tractatio, quam Graeci logismon nuncupant, qua mens sapientiae intenta solidatur."

29 De Jacob $1.28($ CSEL $32.2,22.4-8)$ : "ergo causa bene uiuendi non delectatio corporalis, sed mentis prudentia est. non enim caro, quae subiecta est passioni, sed mens, quae iudicat, quia nihil melius delectat quam consiliorum 
the grounds for living a good life are not to be found in the pleasures of the body but in the sound judgment of the mind, not in the flesh, which is subject to passion, but in the mind, which judges, because nothing is more delightful than virtuous thoughts and beautiful deeds. Thus, the sound judgment of the mind is the mediator of the blessed Iife.

The first criterion for proper behavior, indeed the primary foundation for all action in life, is that passion obey the control of reason (De off. min. 1.105-6).

Rational subjugation of the flesh and its ruling passions is required both as a moral action in itself (or, alternatively, as the prevention of immoral actions) and as protection of the vigor mentis against the enervating effects of uncontrolled feeling (De off. min. 1.98; see n. 13)

That it is both possible for the mind to rein in the appetites and important for it to do so is a common theme in Ambrose's writings, at times stated directly $y^{30}$ and at other times subsumed in the more general idea that the soul must rule the body or that the person must rule himself or herself. ${ }^{31}$ The subjection of passion is

honestas et operum pulchritudo; ea igitur beatae interpres est vitae."

30 See, for example, De off. min. 1.12, 227; Exam. 3.56; De Abr. 2.19, 43; De Noe 90:

31 See, for example, De Isaac 4; De bon. mort. 26; De Abr. $2.1,41 ;$ Ep. $37.7 ;$ De fide $5.102 ;$ and Exp. ps. 118 $2.13,4.7,8.39,14.30$. It is worth noting that in many instances Ambrose uses anima where one might expect mens or ratio in regard to the subjugation of passion. Given his repeated assertion that the mind is the ruling, acting part 
required by the law of nature, recta ratio, by the moral law implanted in us at our creation and continuing to teach us precisely which desires must be repressed (De off. min. 1.228, De Jacob 1.4).

Ambrose, on several occasions, clearly states that, while human passions can be checked or moderated, they cannot be eradicated. ${ }^{32}$

The most seriously blameworthy passion is lust, which reason softens and suppresses. Reason is able to soften it but is not able to uproot it, because the soul capable of reason is not the master but the restrainer of its passions. . . . It [right reason] does not eliminate lust from the soul but acts so that we may not be enslaved to it.

Like lust, anger is also an unavoidable disturbance of the soul, part of the emotions rooted in our very nature; although it cannot be prevented or erased, it can and must be curbed by reason (De off. min. 1.90; Cf. Ep. 63.60). Within us is the inclination to give ourselves over to luxury, lust, pride, and cruelty, but there is also within us the ability to moderate and inhibit our enthusiasms and passions (Exam. 1.31).

of the soul, however, there is little difficulty understanding from the context when anima may be accurately translated as mind or reason by virtue of its function.

32 De Jacob $1.1,2$ (CSEL 32.2, 3.14-4.1, 4.9-10): "passio autem grauissima culpae concupiscentia, quam ratio emollit et conprimit. emollire enim potest, eradicare non potest, quoniam animus qui est rationis capax suarum passionum non dominus, sed repressor. . . . denique non animi excidit concupiscentiam, sed facit ne concupiscentiae seruiamus." 
Because we are embodied creatures, there is no escaping two essential components of corporal nature, anger and fear; it is the wise person's mind that imposes appropriate controls, lest the soul be confounded by a confluence of those passions (De Noe 84). There is no human mind without its share of wild and evil thoughts, but the wise mind is able to calm and control them (De Noe 57): "the self-controlled mind restrains all passions, governs the senses; constrains speech" (De Noe 38). 33 In this context, Ambrose's favored verbs of restraint, control, and inhibition and his specific and repeated denial of the possibility of eradication of passion comport with the philosophical thought of his day. While early stoicism had asserted human ability to eliminate the passions, leaving only non-rational emotional impulses (hormai) that are obedient to reason and exist within reason's bounds, later stoicism abandoned the categorical distinction between hormai and the passions, believing the difference to be one of degree --

33

De Noe 84 (CSEL 32.1, 473.11-16): "sed quia in corpore est, necesse est et iracundiam habeat et timorem, nec potest sine hac esse corporeae necessitate naturae. et ideo mens sapientis moderamina iusta dispensat, ne iram et timorem permisceat et fiat confusio quaedam animo illius atque diluuium."

De Noe 57 (CSEL 32.1, 453.11-15). "nulla enim mens est, nulla anima, quae non recipiat etiam malarum motus agrestes cogitationum. itaque insipientis anima ferinos acuit motus atque adolet venena serpentum. sapientis autem uigor mitigat et coercet."

De Noe 38 (CSEL 32.1, 437.3-4): "mens enim sobria passiones omnes cohibet, sensus gubernat, sermonem regit." 
that is, one of efficacy of rational control -- only. ${ }^{34}$ For later stoics as for Platonists, the goal usually is not (cannot be) apathy but is rather metriopathy, a moderation and constraint of inevitable, ineradicable passion (Rist 1969, 25-36, 182-3, 213; Dillon 1977, 77-8, 112; Spanneut 1973, 52), the language used also by Ambrose. ${ }^{35}$

In rare instances, Ambrose does seem to speak in terms reminiscent of the old stoa: In De officiis ministrorum $(1.187,190)$, he exalts the strong mind and the excellent soul as those which cannot be disturbed by terrors or troubles, affairs or desires (see also De interpel1. 4.28 and Exp. ps. 118 21.16). But these apparent suggestions of apatheia should be understood more in line with Ambrose's view of the vita beata as one which can be neither augmented nor diminished by external influences (De off. min. 2.8-16, De Jacob 1.24-35, Ep. $37.5)$; that is, they are more reflective of the orthodox Stoic view of perfect virtue as self-sufficient (Rist

34 Ambrose's discussion of the relation of horme to ratio, following Cicero (De off. 1.28.101-29.102), puts him clearly in the camp of the later stoics who understand impulse as continually requiring reason's control rather than as being, by definition and in contrast to pathe, already under that control (De off. min. 1.227-8).

35 However, Nussbaum (1994, especially 359-401) describes the continuation of the stoic insistence on the extirpation of the passions in the writings of cicero and Seneca. 
$1969,7-9)$ than descriptive of an apatheic sage. ${ }^{36}$

Ambrose does not claim that rational control of passion is no longer a task for the person attaining a blessed life; rather, such control (now perfected) is assumed to be present in the vita beata, contributing to its security in the midst of life's turmoils.

In this regard, Holte $(1962,170)$ is misleading when, using Cicero's media and perfecta officia (De off. 1.3.8), he links by analogy Ambrose's version of the ciceronian model with Plotinus's two levels of virtue. Ambrose, like Cicero, distinguishes between ordinary and perfect duties, a distinction that Ambrose further shapes into the two types of Christian life: the ordinary life, governed by precepts applicable to all, and the perfect, ascetic life of the few who can follow the counsels of the gospel (De off. min. 1.36-7; cf. De vid. 72-5, Exh. virg. 17). Holte ties cicero's primarily stoic terms and, by extension, the Christian precept/counsel categories to what he considers

36 The possibility of apatheia is suggested in De Jacob 1.32 when Ambrose goes beyond saying that the happy person is not troubled by external woes to claim that he or she does not even feel them. This section shows clear evidence of its Plotinian source, but follows closely upon the part of the treatise indebted to the Pauline epistle to the Romans in which Ambrose asserts that troubles endured, far from being unperceived, serve as test and proof of the perfected, blessed person (1.24, 27; Nauroy 1974, $132 \mathrm{n} .68$ ). That the vita beata cannot be shaken is generally for Ambrose less a philosophical truth -- be it in relation to apathy or to self-sufficiency -- than a demonstration of the scriptural promise that nothing can separate the believer from the secure love of God (Rom. 8.31-9). 
an analogous distinction in the thought of Plotinus between an ordinary human life of controlled passion (metriopatheia) and a divinized, perfect life characterized by the absence of passion (apatheia). Interesting as the connection may be between Ambrose's and Plotinus's versions of the two ways of life, it cannot be said, on evidence from Ambrose's writings, that he understood the life governed by counsels of perfection to be a life of apatheia. Indeed, the paragraphs following Ambrose's use of media and perfecta officia depart from Cicero's version in order to promote mercy, in compellingly compassionate terms, as the very quality which makes human beings perfect (De off. min. 1.38-9).37

Restraint of passion is the essential self-preserving action of reason, for "when the soul is stirred up, the mind is tossed by the waves. "38 Failure in this crucial task threatens the overthrow of the mind from its position of dominance within the soul and, consequently, within the embodied person. ${ }^{39}$ Passionate disturbances, such as

37 Dillon (1977, 151) notes that Philo, another important model for Ambrose, speaks primarily of apatheia rather than metriopatheia, but that his description of pity as a necessary passion trips him up.

38 Exp. ps. 118 8.39 (CSEL 62, 174.12): "rege igitur te ipsum, quando turbatur animus, mens fluctuat."

The metaphor of the dangers of tempestuous seas is also found, not surprisingly, in De Noe (see p.66).

39 De Noe 38 (CSEL 32.1, 437.1): "quod enim in anima mens, hoc anima in corpore." 
anger, that are not checked can glut the soul to the point of dislodging reason from its proper place, its locus within the soul (De off. min. 1.90-2).

Reason's progressive collapse is a downward spiral: if ratio does not restrain passion, the mind becomes agitated and enfeebled, increasingly incapable of exerting its proper authority and maintaining its governing position, and finds itself swamped, drawn into a maelstrom of furor and degeneracy. Ambrose's description of this vicious cycle of moral and mental regression in which the mind becomes incapable of either controlling desire or protecting itself from the effects of the passions run rampant is presented in De officiis ministrorum $1.228-9$, a considerable embellishment of Cicero's De officiis 1.29.102. This image appears elsewhere in Ambrose's writings during an extended explanation of the meaning of the flood in De Noe, especially paragraphs 12 and $30 ;$ the metaphorical language of drowning in one's unbridled appetites is also employed in De Isaac 2 .

If, however, reason is in charge and the passions are restrained, the work of virtue can proceed: "when desires have been suppressed and the mind is calm, then virtues and good works can sprout as from an acceptable seedbed of judgment." 40 with reason's victory in the internal

40 De Noe 77 (CSEL 32.1, 469.7-9): "cum autem compressae fuerint cupiditates et mens requieuerit, tunc seminario quodam disceptationis accepto uirtutes possunt et 
struggle of mind and flesh, the motivating energy of the appetites $^{41}$ can be channeled appropriately to the service of the virtues (De Isaac 7; cf. De Isaac 16, De Cain 1.24, 2.4). The mind focused on reason is the necessary precondition for virtuous practice, and the mind obtains and maintains that focus by training and education. ${ }^{42}$

\section{b) Practice and striving}

The mind, constantly surrounded by the threatening flood-waters of desire, finds the stability it requires, in order to act virtuously and to maintain its control over the passions, in habit and practice, usu atque exercitatione (De interpell. 4.28).

Virtue without practice is as impossible as a warrior without weapons. ${ }^{43}$ virtue without effort is an illusion,

bona opera germinare."

41 Ambrose agrees with Cicero (De off. 1.36.132) that the appetites -- having been submitted to reason -- are the part of the human soul that stimulates action (De off. min. 1.98 ; in 1.227 , appetitus is given as the translation of horme; cf. n.34).

42 De Jacob 1.1 (CSEL 32.2, 3.2-5): "Necessarius ad disciplinam bonus sermo omnibus, plenus prudentiae, et mens rationi intenta praecurrit uirtutibus, passiones coercet; docibilis enim uirtus. denique studio et discendo quaeritur, dissimulando amittitur."

43 De Cain 1.12 (CSEL 32.1, 347.19-22): "apud ignauos enim nulla sunt insignia uirtutis, apud sapientes prima habentur; studia enim uirtutis quaedam instrumenta sunt. itaque sicut bellator sine armis esse non potest ita nec sine exercitatione uirtus."

The military metaphor was a philosophical commonplace; see, for example, Cicero (De senectute 73), who 
for the effort is the very manifestation of the virtue. ${ }^{44}$ The importance of repeated right actions for formation of the good and wise person is a commonplace in stoicism from its earliest days through Ambrose's era (Rist 1969, 14-17; Spanneut 1973, 52; Long 1986, 201-4), and is emphasized throughout his writings, not only in De officiis ministrorum, following cicero, but also in the exegetical works more strongly influenced by Philo and Plotinus.

The requisite exercitatio applies not only to the habitual performance of virtuous deeds but also to the mental preparation for and attention to education, for "how can there be teaching without practice or progress without habit?" ${ }^{45}$ The ideas and behavioral habits that have become inveterate through practice and training are the ones accessible for explanation by more formal teaching methods. ${ }^{46}$ Bolstering this belief is Ambrose's apparent acceptance of the traditional philosophical claim that virtue is teachable (De Jacob 1.1 [see n.41]; Holte $1962,26,175$ n. 4):

attributes it to Pythagoras, and Seneca (Ep. mor. 59.7-8), who cites sextius.

44 De Cain 2.8 (CSEL 32.1, 384.17-8): ". . nulla enim sine labore uirtus, quia labor processus uirtutis est."

45 De off. min. 1.31 (PL 16, 33A): "Quomodo enim sine exercitatio doctrina, aut sine usu profectus?"

46 De off. min. 2.25 (PL 16, 110B): ".. . ut ea quae mentibus ac moribus vestris usu atque institutione inolita atque impressa sunt, etiam sermone ac disciplina aperiantur." 
Practice alone, without the gift of innate intelligence, accomplishes nothing but so, too, natural wit is worthless in the absence of appropriate training and education of the inborn faculties. As Ambrose states, in an exegesis of Genesis 12.6 in which Abraham arrives at an oak tree at Shechem ("For Shechem signifies either shoulder or neck, which is evidence of effort and practice") : ${ }^{47}$

Therefore, because practice itself, without the endowment of nature, cannot by itself bestow perfection and because the gift of nature is lost if there is no practice (for diligence is the support of natural talent), the man whom you are being fashioned to imitate, the man who was made more deeply rooted and more lofty by practice added to his natural gifts, is led straight to the tall oak.

The idea that ingenium requires the support of diligentia to come to full fruition is taken up again in a later work, where Ambrose lauds the addition of time-consuming assiduity to the timeless gift of natural ability; here the fertile combination results in Jacob's rapid and successful enactment of his mother's plan to secure Isaac's blessing for himself instead of Esau (De fuga 4851).

47 De Abr. 2.8 (CSEL 32.1, 570.7-9, 10-6): "Sychem enim uel umerus uel ceruix significatur, quod est laboris et exercitationis indicium. . . . ergo quia neque sine dote naturae exercitatio ipsa per se perfectionem conferre potest et naturae gratia destituitur, si desit exercitatio -- est enim ingeniosi adminiculum diligentia --, inducitur is uir, ad cuius imitationem formaris, ad naturae gratiam adiuncta exercitatione ita fundatior et excelsior factus, ut usque ad quercum altam pertransiret." 
Diligence and time are necessary ingredients of the struggle for wisdom (De fuga 51) and there are even a few persons who can attain a life of blessedness and goodness by virtue of the quality of their thoughts and judgments and of the strenuousness of their efforts (De off. min. 1.124-5)..$^{88}$ Thus, it is both possible and laudable, in Ambrose's thought, to strive for the highest knowledge and stretch oneself to reach all that is above one; the mind is able to direct itself "to the heights of the heavens by its eagerness for knowledge and its passion for wisdom" (Ep. 43.15 ; see n.19).

The goal of practice, of the struggle for moral improvement and intellectual attainment, is characterized by Ambrose as both a process of perfection and an ascent towards wisdom and the realm of the invisible, the immaterial, the immortal.

48 The notion that there are a few who can attain such excellence by dint of their own efforts is also found in the discussion of the "cities of refuge" in De fuga 11. There, as in the passage from De officiis ministrorum, it is expressed with the emphasis on the negative claim that only a few are capable of such an achievement.

In his 75 th letter, Seneca says much the same about the value of effort but relative rarity of achievement. He describes three levels of progress toward perfection -three categories of the proficiens -- and seems to regard not only perfection itself but even the highest plateau of progress as virtually unattainable. He claims that the second level is so difficult to reach that we should rejoice if we can even make it to the third level. Ep. mor. 75.15: "Magna felicitate naturae magnaque et adsidua intentione studii secundus occupatur gradus; sed ne hic quidem contemnendus est color tertius." 
c) Perfecting and Ascent

In De Isaac vel anima 68, Ambrose depicts, in broad strokes, the three stages of the soul's advance: first, instruction (institutio); second, progress (profectus); third, perfection (perfectio). Another three-fold description, this time in the more specific circumstance of the response to an insult, classifies a person as either one who returns injury for injury, or one (the proficiens) who does not respond at all, or one (the perfectus) who actually blesses the insulter (De off. min. $1.232-4) \cdot 49$

In these passages and elsewhere Ambrose speaks as though perfection were a possibility for human beings and their works within an earthly lifespan. When he praises the gifts of wisdom in De Abraham, he avers that "it is not possible for one who acquires wisdom not to be good and perfect." 50 In the commentary on Luke's gospel

49 It should be noted that, in this allusion to the perfectus, there is again no suggestion that such a person is characterized by apatheia. On the contrary, the perfectus is aware of and responds to the insult in the same manner as did Paul, who first "Conquered and calmed his human emotion" (De off. min. 1.234 [PL 16, 92C]: "Ideo ergo Paulus persecutionem patiebatur, et sustinebat, quia vincebat et mitigabat humanum affectum propositae mercedis gratia . . ") .

50 De Abr. 2.76 (CSEL 32.1, 3-4): "non potest igitur bonus atque perfectus non esse qui hanc [sapientia] adquisierit."

Other uses of perfectus as a modifier (of various nouns) include De Abr. 2.46 (the mind), De Cain 2.8 (works), De Isaac 57 (the soul), and Ep. 16.5 (man). In Exp. ps. 118 13.3, Ambrose states that the entire psalm is about the 
(1.31), Ambrose defines the vir perfectus as one who is no longer prey to the errors and inconsistencies of youth but whose soul has reached maturity. ${ }^{51}$

Ambrose links the vita beata with perfection: ${ }^{52}$

The happy life does exist among humans but in those, of course, in whom life has been perfected. That perfect life is not a sensual one but a rational life lived according to reason's judgment and the mind's vital energy. In this there is not just a portion of the person, but his perfection, which exists not so much in his status as a human being as in his action, for it is that which creates happiness.

This passage, heavily dependent on Plotinus (Solignac 1956, 150-1; Nauroy 1974, 133), nevertheless includes a signal revision of Plotinus's thought. As Holte (1962,

perfection of human beings (perfectionem hominis), but the context, and his claim in 22.1 that the 22 nd letter signifies profectum hominis, suggest that here he is speaking of the process and not the ultimate result.

51 Tissot, the translator of this work for sources chrétiennes, has rendered vir perfectus as l'homme fait. While it is not inconceivable that perfectus is here better translated as "grown-up" or "adult," since maturity seems to be the focus, the context suggests otherwise. The preceding sentences make the point that the age of the soul is to be assessed on the basis not of years but of extent of virtue, and the term put in opposition to perfectus is pusillus, a word that does not connnote immaturity and that, furthermore, is explicitly defined by Ambrose as one who is not advancing in virtue. Thus, it seems clear that he is here using the word perfectus in precisely the sense of moral perfection and not of chronological completion.

52 De Jacob 1.29 (CSEL 32.2, 22.17-22): "est ergo beata uita in hominibus, sed in his scilicet, in quibus fuerit perfecta uita. perfecta autem uita non sensibilis ista, sed illa rationabilis secundum tractationem rationis et mentis uiuacitatem. in quo non est portio hominis, sed perfectio, quae non tam in condicione est hominis quam in operatione; haec enim beatum facit." 
173-4) explains, the philosopher defines the perfect life in terms of reason alone, in the exercise of speculative thought, and believes its attainment to be a potential inherent in human nature. Ambrose, in contrast, explicitly links perfection not to the human condition per se but to works, and thereby underlines once again the moral force that the notion of perfection holds for him. Despite Ambrose's use of perfectus, more often than not he equivocates on the question of whether perfection is possible during earthly existence and focuses instead on the process of perfecting -- the life and conduct of the proficiens -- rather than on ultimate perfection itself. This interest in moral progress is likewise found among the philosophers -- especially the stoics -- whose ideas formed the intellectual milieu of the fourth-century Western world. ${ }^{53}$

Cicero asserts that his treatise on duties concerns the ones stoics classify only in the second rank, applicable to all persons as well as to the perfected sage, but that observance of those ordinary duties is nonetheless required for progress towards virtue. His argument about less-than-perfect morality includes the observation that his readers habitually label as "wise"

53 Seneca's Epistulae morales $75.8-18$ is a discussion of the three ascending classes of proficientes. See Long $1986,177,213-5,233$; Rist 1969, 13-8, 90; Dillon 1977, 151 n.1. 
persons who were not at all the models of perfect wisdom of which orthodox stoicism speaks (De off. 3.4.15-17). At the correlative point in Ambrose's version, he rewrites Cicero's distinction in wisdom between ordinary persons and the sage as the difference between human and divine wisdom. This being done, it is then a logical next step to separate the profectus from the perfectus by death, apparently denying the possibility of true perfection during earthly existence: ${ }^{54}$

There are two sorts of perfection: one having middling rank, the other being the most advanced category; one applies now, the other then; one is in accordance with human potential, the other with the perfection to come.

More bluntly put, middling perfection is no perfection at all, for "here everything is imperfect, there all is perfect. $.1{ }^{55}$

However, Ambrose then turns back in the direction of cicero by acknowledging differing levels of human wisdom and citing Daniel and Solomon as examples of a perfect wisdom attainable in this life -- a wisdom which, it turns out, is equivalent to moral perfection, contrasted now not

54 De off. min. 3.11 (PL 16, 148C): "Duplex enim forma perfectionis: alia medios, alia plenos numeros habens; alia hic, alia ibi; alia secundum hominis possibilitatem, alia secundum perfectionem futuri."

55 De bon. mort. 49 (CSEL 32.1, 746.2-3): ". . ex parte enim hic cognouimus, quia hic inperfecta illic perfecta omnia, hic paruuli illic robusti." 
to moral progress (via the performance of ordinary duties) but to frank injustice: ${ }^{56}$

There is also diversity among human beings. . . It is one thing to be commonly wise; it is another to be perfectly wise. Those who possess common wisdom are wise in temporal matters and wise for themselves so that they may take something from another and give it to themselves. Those who are perfectly wise do not know how to consider their own advantage but direct themselves entirely toward the things that are eternal and proper and good, seeking what is useful not for themselves but for everyone.

At the beginning of the second book of De Abraham, Ambrose steps away, for the most part, from his ambivalence about temporal perfection and trains his eye instead on the process that has perfection as its goal, regardless of venue. Here he declares his intent to use the stories of various personages to demonstrate the progress of virtue. Abraham's narrative is offered as an example of such a process, especially when considered in contrast -- and as the sequel -- to the tale of Adam and Eve, in which it is a matter, not of moral progress, but of a precipitous decline from the highest level of virtue.

56 De off. min. 3.12 (PL 16, 148C-149A): "Inter ipsos quoque homines distantia est. . . . Aliud est enim communiter sapere, aliud sapere perfecte. Qui communiter sapit, pro temporalibus sapit, pro se sapit; ut alteri aliquid detrahat, et sibi adjungat. Qui perfecte sapit, nescit sua spectare commoda; sed ad illud quod aeternum est, quod decorum atque honestum, toto affectu intendit, quaerens non quod sibi utile est, sed quod omnibus." 
Abraham's advance towards perfection will then teach us "how a broken mind can re-form itself. "17

Although there are times when Ambrose seems to present Abraham as the model of the vir perfectus, his explicit attention consistently falls not on the patriarch's perfection but on his journey towards that goal: ${ }^{58}$

It is the progress of the wise man, offered to us for emulation, and not his perfection that has been recorded as an exemplary experience. For so the mind, which in the first man had fallen, in Abraham re-forms itself and thus gathers itself together by degrees and stages of growth.

The human mind does not begin in perfection but is capable of advancing by degrees ${ }^{59}$ and, while it is not possible for every aspect of a person always to be perfect, yet one

57 De Abr. 2.1 (CSEL 32.1, 565.4-6): ". . ita etiam processum mentis et quendam superiorem reditum significaret, ut quemadmodum infracta mens reformare se possit cognosceremus."

See also De Abr. 2.37 and 2.41 for further references to the mind's progress. Proficiens is used in relation to the soul in Ep. 70.7 and 71.4 , and in Ep. 23.5 Ambrose speaks of those who are beginning to be perfect.

58 De Abr. 2.5 (CSEL 32.1, 568.8-12): "sed, ut dixi, processus uiri sapientis propositus nobis ad imitandum scriptus est ad experimentum, non perfectio. adhuc enim reformat se mens in Abraham, quae in homine primo lapsa est, et ideo per gradus et incrementa se colligit."

59 That nature gives persons reason "in an imperfect but perfectible form" is part of the stoic philosophy of nature, according to Long $(1986,168)$. Rist $(1969,40)$ makes basically the same observation and attributes it to seneca, citing Ep. mor. 120.4 ("Hoc nos natura docere non potuit: semina nobis scientiae dedit, scientiam non dedit") and 94.29 . 
can work to increase the proportion of good relative to the evils in one's life (De Abr. 2.26).

In Ambrose's commentary on Psalm 119, another exemplary patriarch, Moses, is described as having advanced to higher things by progressing in virtue (Exp. ps. 118 17.15). And elsewhere in that work, as Ambrose explains the need for repentance before the reception of sacramental grace -- the baptism of John before the baptism of Christ -- he speaks of the upward path not as accessible only to persons of Moses' stature, but as open to human beings in general, who "are not capable of being perfect from the first, but ascend through an advance in virtue. 160

The motif of ascent complements Ambrose's other themes of practice, striving, and the advance toward perfection. Just as Jacob was capable, by his vigor mentis, of leaving his body and entering paradise at will (De Jacob $2.38[\mathrm{n} .14]$ ), so "his mind ascended into the heavens by means of his virtues, as though they were

60 Exp.ps. 11816.19 (CSEL 62, 363.9-16): "praesumimus tamen, eo quod utrumque oculum una anima habeat, et oculum suppliciorum et oculum gratiae, laeuum oculum suppliciorum, dextrum gratiae, quia non a primo homines possunt esse perfecti, sed per processum uirtutis ascendunt. ante igitur unaquaeque anima quasi ad baptismum Iohannis uenit, ut praemittat paenitentiam delictorum, et in processu paulatim, ubi sua peccata defleuerit, spiritali abluta baptismate Christi accipit sacramentum." 
steps, and he knew the secret things of God and was strengthened and filled."61

Often Ambrose's reference to the mind's or soul's ascent freely uses metaphors of wings and chariots that immediately bring to mind images used by Plato in the Phaedrus. Courcelle $(1968,109-10)$ finds a clear Platonic influence, mediated through Plotinus, reflected in Ambrose's discussion of the soul's winged ascent in De Isaac $78 .^{62}$ The Platonic background is perhaps even more obviously present in Ambrose's three extended references to the soul as chariot. In each instance, however, Plato's chariot becomes a biblical vehicle, twice the chariot of Ezekiel (Ez. 1.4-25; De Abr. 2.53-4; De virginitate 111-9) and once that of Aminadab (S. of S.

61 De fuga 22 (CSEL 32.2, 182.7-9): "his ergo uirtutibus uelut gradibus quibusdam mens eius ascendit in caelum, et dei secreta cognouit et confirmatus est et repletus . . ."

62 Nauroy (1985a), on the other hand, believes the Plotinian influence on De Isaac to be insignificant in the light of Ambrose's overriding focus on allegorical exegesis of the Song of Solomon, influenced primarily by origen.

other passages in which Ambrose refers to the soul's wings as its means of ascent include De virginitate 107-110, Exp. evang. sec. Luc. 7.114, and De fuga 17, 27-31 (not a surprising finding in the latter treatise dedicated to the soul's flight from the world).

otten (1966) stresses Ambrose's Christianization of the image of ascent but notes (448) that "in his account and analysis of the mystical ascent he draws with confidence and discrimination upon the treasury of Neoplatonism, blending it skillfully and masterfully with the fund of the Scriptures." 
6.12; De Isaac 65); in De Abraham (2.54) Ambrose expressly claims Ezekiel as the source of Plato's image. 63

Courcelle (1968, 312-19) and Savon (1977b, 1:151,

368) differ both in their willingness to imagine Ambrose referring directly to Phaedrus as he wrote the works that bear its impress and in the strength of their attribution of a mediating role to Philo (rather than to Plotinus). However, they agree that, while there is no way to prove whether Ambrose had read the original phaedrus, it cannot be questioned that he knew the myth well.

Beyond talk of wings and chariots, however, Ambrose's discussions of the soul's ascent are marked by the consistency with which he attributes the climb to the exertions of the human mind, especially in its governance of moral conduct: ${ }^{64}$

The good soul despises visible, sensible things and does not linger over them, nor does it dwell upon and sink within those things which should be condemned. But, raising itself up by means of a pious mind's pure perception, it ascends to those things that are eternal and invisible and full of wonders. For, devoted to perfection, it aims at that good alone that is divine and does not think

63 Mähl (1969, 12-4) discusses Ambrose's allegorical discovery of the four cardinal virtues within the stories of Ezekiel's and Aminadab's chariots.

64 De Isaac 11 (CSEL 32.1, 651.7-11): "anima ergo bona contemnit uisibilia et sensibilia nec consistit in eis nec in despiciendis his inmoratur et residet, sed ascendit ad illa aeterna et inuisibilia et plena miraculis puro sensu se piae mentis adtollens. etenim perfectioni studens solum illud bonum divinitatis intendit nec aliud quicquam requirendum putat, quia tenet quod summum est." 
that anything else should be sought because it possesses the best.

As was the case with Jacob, the upward trek powered by the mind's vigor is effected primarily by its virtuous actions -- the mystical ascent remains grounded in moral conduct -- and, like Jacob, anyone who attains paradise by means of virtue's ascent will be privy to divine secrets (De par. 53). The soul rises up "by dint of its strength and virtue"; it "lifts itself to higher things by means of good judgments and works." More specifically, the elevating thoughts and actions that enable the soul's climb center on a longing for learning and on love for human beings. ${ }^{65}$

It is not surprising that scriptural references to mountains call forth from the allegorically inclined Ambrose exegetical excursions about spiritual ascent. This is true of the mountain approached by Abraham at Bethel, the ascent of which is evidence of progress on the part of the proficiens (Gen. 12.8; De Abr. 2.11, 13), and of the mount from which Jesus preached his ethical sermon,

65 De Isaac 53 (CSEL 32.1, 677.14-6): "[anima] surrexit, ut proprius illud dei uerbum uideret. et in hoc ipso processus eius significatur, quod surrexit per uigorem atque uirtutem."

Ep. 71.10 (PL 16, 1243A): "Haec est anima Evangelica - . et ad superiora se bonis consiliis et operibus attollens. . ."

Ep. 43.11 (PL 16, 1132B): "Quorum alia ministraret abundantia copiarum terrestrium ad voluptatis perfunctionem: alia cognitio secretorum coelestium, quae mentem inflammaret hominis amore et desiderio disciplinarum, per quas ad sublime illud divinorum penetralium possimus pervenire." 
which is climbed "not by the body's footsteps but by more lofty deeds."66 similarly, the Mount of Transfiguration evokes the warning that, "unless you ascend the peak of loftier prudence, wisdom does not appear to you." 67

Ambrose can with facility speak in the common philosophical parlance of his day when it is a matter of reason's role in subduing passion, or of training the mind to enact good works, or even of the arduous route of the proficiens. Although, as we shall see, such topics may at times lead him to more specifically theological and scriptural allusions and exhortations, they can and often do stand alone as ways of understanding human psychology and action that are acceptable to Ambrose and compatible with his beliefs and his ecclesiastical purposes. But, when it finally comes to the language of the ascent which the proficiens undertakes, Ambrose cannot fail to tie that notion immediately to Christian belief, for with the metaphor of ascent he must inevitably speak of its goal and, therefore, he must speak of God. This is evident in the passages cited above which refer to penetration into the divine mysteries at the summit of the climb.

66 Exp. evang. sec. Luc. 5.41 (CC 14.4, 149.451-2): "Non uestigiis corporalibus, sed factis sublimioribus in hunc montem ascendas."

67 Exp. evang. sec. Luc. 7.12 ( $\underline{\text { CC } 14.4,218.134-7): ~ " E t ~}$ haec enim mysteria sunt et referuntur altius; etenim pro tua possibilitate tibi uerbum aut minuitur aut crescit, ac nisi altioris prudentiae cacumen ascendas, non tibi apparet sapientia, non tibi apparet mysteriorum cognitio . . " 
Once the metaphor of ascent leads to theological discourse, however, it becomes more difficult to attribute the soul's elevation to its own efforts alone. Consequently, Ambrose can say, in De fuga saeculi, that Jacob's mind attains heaven and the knowledge of God by, as it were, scaling the ladder of his own virtues (De fuga 22 ; see $\mathrm{n.60)}$, but he must also ask how anyone can possibly ascend without God's help: "Who is so blessed as to ascend ceaselessly in their own hearts? But how can this be done without divine assistance? In no way, without question." 68 The point is raised again elsewhere: "For who can ascend by human steps, without divine guidance, from earthly things to heavenly, from the shadow to the light, from the exemplar to the innermost reaches of the truth?" 69

It is in the farther reaches of reason's efforts, the attempts to attain knowledge of the eternal, the invisible, the things of God, that reason's limits become clear. The inability of the human mind to penetrate cosmic secrets without divine illumination and revelation is, for Ambrose, not only the counterbalance to

${ }^{68}$ De fuga 2 (CSEL 32.2, 163.14-164.1): "quis autem tam beatus, qui in corde suo semper ascendat? sed hoc sine auxilio divino qui fieri potest? nullo profecto modo."

69 Exp.ps. 1183.25 (CSEL 62, 55.24-6): "quis enim de terrenis ad caelestia, de umbra ad claritatem, de exemplari ad penetralia ueritatis humano gradu sine diuino ductu possit ascendere?" 
philosophy's humanistic and, at times, rationalistic focus, but also the consistent warning in his own writings against any insufficiently qualified praise of reason. The definition of the human being lies not only in the person's possession of reason; more important, homo is one who has the capacity for both reason and grace, who is capax rationis et gratiae. ${ }^{70}$

70 De interpel1. 3.26 (CSEL $32.2,263.11-7$ ): "circumfusus enim dei gratia incipit homo esse qui per imprudentiam praetendebat insensibilitatem et inscientiam bestialem; homo enim eo probatur, si capax sit rationis et gratiae, itaque a mutis animalibus separatum esse se gaudet et in hominum adscitum esse consortia, quae deus uisitat et tuetur. quid est enim homo nisi quia eius memor est dominus aut quia a domino uisitatur?" 


\section{CHAPTER THREE \\ THE LIMITS OF REASON \\ Ambrose as Antiphilosopher}

\section{Reason and God}

Ambrose is fully capable, as the last chapter shows, of lauding human reason in terms and for purposes similar to those that his contemporaries of a non-Christian philosophical bent might choose. However, in the context of the whole of his writings it is also clear, as will be shown, that for him the important thing to say about reason is that its beginning and end lie in God. Philosophy is useless, and even dangerous, because it has forgotten its origin in the stories and revelations of scripture and has consequently directed itself toward false ends. In just the same sense, reason cannot be the dominant faculty it is meant to be unless it fully acknowledges its creating source and focuses solely on its proper destiny, the bosom of God.

Each aspect of Ambrose's views on reason mentioned earlier also finds somewhere in his writings its theological qualification, an appended reminder of reason's constant and necessary relation to God. Human beings are capable of reason only because God created them 
so (Exam. 6.75) and the mind must be yielded back to God if the proper moral work of reason is to proceed: 1

For it is an excellent thing to bestow your favors and duties on the fellowship of human beings. But, what is fitting above all is that you assign back to God your most precious possession, that is, your mind, than which you have nothing more outstanding. When you have absolved the debt to the creator, then you may bestow your works of kindness and aid toward people.

Even the strains of Ambrose's thought -- those concerning the constraint of passion, the need for practice, and the route to perfection -- that show him to be conversant with and generally accepting of the moral and psychological tenets of his philosophical milieu concerning the role of reason are at times also connected explicitly to reason's relation to God.

Both the requirement and the ability to exert rational control over the passions come from God: ${ }^{2}$

For when God created human beings and implanted in them moral sense and feelings, God then established the royal rule of the mind over the emotions so that all human feelings and emotions would be governed by the mind's strength and power.

1 De off. min. 1.252 (PL 16, 100B): "Pulchrum est enim ut gratiam tuam atque officia in societatem humani generis conferas. Sed primum illud decorum est, ut quod habes pretiosissimum, hoc est, mentem tuam, qua nihil habes praestantius, Deo deputes. Cum solveris auctori debitum, licet ut opera tua in beneficentiam et adjumenta hominum conferas

2 De Jacob 1.4 (CSEL 32.2, 6.8-11): "etenim cum deus hominem constitueret et in eo mores sensusque plantaret, tunc motibus eius regale inposuit mentis imperium, ut omnes sensus motusque hominis eius uigore ac potestate regerentur." 
The Word of God acting within us separates our rational powers from the potentially fatal passions of the body (Ep. 4.5). Only the mind fixed on God and supported by divine favor is capable of overcoming the temptations of bodily delights and worldly snares (De Abr. 2.41, 45). In sum, the mind must be firmly under God's control if it is, in turn, to exercise its delegated control over the irrational portions of the human soul (Exp. ps. 118 10.18, $2.35)$

In De officiis ministrorum 1.180-4, after Ambrose discusses the place of practice and training among the bases of the virtue of fortitude, he proposes such exercises as the foundation of the Christian endurance of persecution. Quoting 1 Timothy 4.7, Ambrose exhorts his readers to train themselves towards piety; the godliness thus attained will, in its turn, train them towards justice and other virtuous traits. In his commentary on Psalm 119, he speaks of daily scripture reading as the mental exercise of choice (4.13) and asserts that it is by meditating on heavenly precepts that the practice of good works will become inveterate (6.35)

Ambrose's apparent ambivalence about the possibility of earthly perfection is made clearer by his occasional claim that the attainment of perfection is directly dependent on one's relation to Christ: "The mind is good if it is focused on reason, but hardly perfect unless it 
is under the governance of christ. " 3 Perfection requires not only faith, but the grace of baptism and the redeeming blood of Christ (Ep. 7.20).

In a paragraph that evokes the similarities and differences between the philosophical ideal and the Christian ideal in his thought, Ambrose describes persons who approximate the characteristics of philosophy's sage: they are those who train for angelic lives by keeping themselves inviolate, who restrain their physical passions, who quiet their minds in tranquility, and who generously and mercifully give to the poor. However, for Ambrose such persons do not represent the individual attainment of a human perfection; rather they are a sort of heaven on earth, not in the stoic sense by being an apospasma of the divine, but by being those in whom God is at home. ${ }^{4}$

3 De Jacob 1.17 (CSEL 32.2, 16.6-8): "mens itaque bona, si rationi intendat, sed parum perfecta, nisi habeat gubernaculum Christi."

4 Exp.ps. 118 12.12 (CSEL 62, 257.24-258.14): "sunt etiam in terris caeli qui enarrant gloriam dei. qui sunt isti caeli? audi dicentem: 'sicut portauimus imaginem illius terreni, portemus et imaginem huius caelestis.' isti igitur caeli sunt qui etiam in terris positi audent dicere: 'nostra autem conversatio in caelis est.' isti sunt caeli in quibus fides grauitas continentia doctrina uita caelestis. nam quemadmodum terra dictus est, qui lapsus ex illa praeuaricatione caelestis gratiae et in haec uitia terrena deiectus praeuaricationis suae uinculis se ligauit, ita e contrario caelum dicitur, qui uitam angelorum custodia integritatis exercet et corpus suum continenti sobrietate moderatur, mentem quoque suam miti tranquillitate componit, pecuniam pauperibus misericordi liberalitate dispensat. est ergo et in terris caelum in quo possunt uirtutes esse 
In a larger sense, exercising reason in any way must be intimately connected with one's life in God; it is, in fact, an imitation of what God does. Ambrose explains Psalm 119.107 ("Give me life, o Lord, according to thy word") in this way: ${ }^{5}$

Therefore, he [David, the psalmist] asks to be given life according to the word so that he may live according to the word and do all things with reason and not by the will of the flesh. Thus the mystical meaning can also be understood morally: ' In the beginning was the word and the word was with God and the word was God. The word was in the beginning with God. All things were made through him and nothing was made without him.' Be also an imitator of God. How so? Could you make the sky or the earth or the sea? Not at all. But you may do everything through the word, nothing without the word; everything with reason, nothing without reason. For you are not irrational, o man, but rational.

caelestes. 'caelum mihi thronus' [Is. 66.1] ego magis iusti affectum quam elementum intellego. illum puto caelum ad cuius animam uenit christus et pulsat ianuam et si aperueris, ingreditur. nec solus ingreditur, sed etiam cum patre, sicut ipse ait: 'ego et pater ueniemus et mansionem apud eum faciemus."

5 Exp.ps. 11814.23 (CSEL 62, 313.7-17): "ideoque se uiuificari secundum uerbum petit, ut secundum uerbum uiuat et omnia cum ratione faciat, non secundum carnis uoluntatem. unde mysticum illud etiam moraliter accipi potest: ' in principio erat uerbum et uerbum erat apud deum et deus erat uerbum. hoc erat in principio apud deum. omnia per ipsum facta sunt et sine ipso factum est nihil.' et tu imitator esto dei. quomodo imitator? numquid caelum potes facere aut terram aut mare? non utique. sed ut omnia per uerbum facias, nihil sine uerbo, omnia cum ratione, nihil sine ratione, quia non es inrationabilis, 0 homo, sed rationabilis." 


\section{The limits of reason}

Beyond his reminders that the moral rule of reason, exercised in self-control and works, requires submission to and imitation of God, Ambrose also ties his views of the more speculative work of reason to God by emphasizing both the inability of human reason to know the divine mysteries and the presumptuousness of the attempt. Not only is the good that characterizes God beyond every human mind and understanding (De Isaac 79, De fuga 36), but also it is neither permissible nor possible for human beings to penetrate the secrets of God's cosmos, as God made clear to Job and to all of us through Job's lesson: 6

o man, you are not allowed to know the heights of wisdom; thus it has been written for you: "Do not seek to understand higher things, but fear." Why do you desire to search curiously into that which it is neither advantageous for you to know nor given to you to learn? . . You are not permitted to know the counsels of the earthly emperor, yet you want to know divine counsels? You are not permitted to search more carefully into the things that happen on earth, yet you inquire more carefully into what is done above the sky? Why do

6 De interpel1. 1.29 (CSEL 32.2, 229.17-20, 25-230.5, 9-14): "non tibi licet scire, o homo, alta sapientiae; ideo tibi scriptum est: 'noli altum sapere, sed time.' quid curiose cupis inuestigare quod tibi scire non expedit nec cognoscere datur? . . imperatoris tibi huius in terris non licet scire consilia, et uis scire diuina? non licet tibi curiosius inuestigare quae in terris geruntur, et curiosius requiris quid supra caelum agatur? cur tu disputas unde nata sit sapientia? nescit homo uiam eius, nec in hominibus inuenta est perfecta sapientia. . . . supra te est scire, o homo, altitudinem sapientiae, satis est tibi ut credas. 'si enim non credideritis,' inquit 'nec intellegetis.' abyssum scire non potes, abyssum non potes conprehendere, quomodo altitudinem sapientiae conprehendes? abyssus dixit: 'non est in me,' et tu potes dicere quia in te est sapientia? 
you debate the origin of wisdom? Human beings do not know wisdom's path, nor has perfect wisdom been found among us. . . O man, it is beyond you to know the height of wisdom; it is enough for you that you believe. "For if you do not believe, neither will you understand." You cannot know the abyss; you cannot understand the abyss. How could you understand the height of wisdom? The abyss has said, 'It is not in me,' and can you say that wisdom is in you?

The limits of human reason in the matter of cosmological speculation are emphasized in Ambrose's series of sermons on the six days of creation, the Exameron. He begins the first sermon by noting that philosophers of various schools debate the question of the world's genesis, all to no avail. Because they rely solely upon human reasoning, they inevitably end in error and confusion. Only Moses, inspired by God, was able to speak the simple, succinct, revealed truth that, in the beginning, God created all things (1.1-5). Because human beings do not have God's vision, we are not to assess the things God has created nor gather our own opinions about them (2.3); even solomon, possessor of divinely conferred wisdom, could not fully explain the nature of created things (3.64). There are forms of knowledge, such as the measurement of immense dimensions, that are impossible for human reason to grasp and presumptuous to attempt (6.7). Ambrose's primary argument against cosmological speculations completes his praise of the orderliness and manifest design of creation: "All these things the divine power, incomprehensible to human minds and inexpressible 
in our words, has devised by the authority of its own will." ${ }^{7}$ Incomprehensible, ineffable, sovereign divinity -- including all the works and ways of God -- is not accessible by unaided human reason.

Similar ideas also appear in Ambrose's other exegetical works. Life in the body is lived always in the shadow where it is not possible to see perfectly or wholly (Exp. ps. $1183.18,8.17-18$; Exp. evang. sec. Luc. 6.58). Moreover, attempting to go beyond the divinely-determined limits of the created mind's grasp may be as dangerous as it is futile; after all, Adam's sin was in wanting to know what it would not profit him to know (Exp. ps. 118 8.24).

For Ambrose, the limits of reason illuminate and define the difference between human wisdom and divine wisdom. Human wisdom is the best human reason can do -and often it is also the worst because, when rootless, reason so easily strays from the truth. Even at its best, unaided human reason cannot approach the whole of divine wisdom. Like the woman with the flow of blood (Lk. 8.43), it can touch only the fringe of the garment, never the cloak itself. ${ }^{8}$

7 Exam. 2.1 (CSEL 32.1, 41.13-5): "quae omnia uis diuina inconprehensibilis humanis mentibus et ineffabilis sermonibus nostris uoluntatis suae auctoritate contexuit."

98): $\frac{\text { Exp. evang. sec. Luc. } 6.58 \text { (CC 14, 194.588-92, 595- }}{\text { "Quod est euidentis indicii quia non intra }}$ possibilitatem condicionis humanae atque intra corporis claustrum inclusa sapientia, diuinitas coartata est, non capitur angustiis corporalibus, non tenetur, sed ultra fines 
3. Human wisdom and divine wisdom

Merely human wisdom receives a variety of labels in Ambrose's writings: wisdom of the world, wisdom of the flesh, philosophy, heresy, Judaism. Although he does at times differentiate among these subtypes of earth-bound wisdom, it is clear that for Ambrose the most important identifying characteristic of each is the one they hold in common: separation from the one true source of wisdom, God the creator revealed in scripture. 9

This "doctrinal dualism" (Madec 1974c, 229, 236), that lumps together all that Ambrose views as perversions of divine reality into one composite enemy. of the truth, is summarized in the concluding peremptory statement of Voluptas in Ambrose's version of pleasure's debate with

nostrae mediocritatis uirtus exundat aeterna. . . Nunc si consideremus quanta sit fides nostra et intellegamus quantus sit dei filius, uidemus quia conparatione eius fimbriam tantummodo tangimus, superiorem uero uestimenti eius partem nequimus adtingere."

9 The Jews are included among the deniers of the creator, in Ambrose's eyes, because their "refusal" of the Christian revelation signals their forfeiture of the truth contained in their own scripture. Judaism, like pagan philosophy, has cut itself off from its source, and has gone astray from the path limned by its own ancestors.

Exp. ps. 118 8.60: "For how can you who deny the author of knowledge possess the key to knowledge?" (CSEL 62, 189.6-7: "quomodo enim clauem potestis habere scientiae qui scientiae negatis auctorem?")

Exp. ps. 118 12.19: "But because later offspring of the Jews strayed from the customs of the fathers, the truth left them and came to the church." (CSEL 62, 262.5-7: "sed quia posterior suboles Iudaeorum a patrum moribus deuiauit, recessit ab illis ueritas et ad ecclesiam uenit.")

Also Exp. ps. 118 13.4, 14.32, 21.12 . 
virtue: "Therefore believe either in philosophy or in the wisdom of Solomon." "Philosophy" in Ambrose's usage generally entails its congeners, all of the errors that make up merely human wisdom. ${ }^{11}$

The dualism is given allegorical warrant in the distinction between Abraham's wife Sarah and her servant Hagar, who successively personifies all the subtypes of worldly wisdom: ${ }^{12}$

10 De Cain 1.14 (CSEL 32.1, 351.20-1): "ergo uel philosophiae uel sapientiae solomonis credite."

It is interesting to note that the only English translation of De Cain et Abel (Savage 1961, 372), by erring in the translation of this sentence (rendered as "Put your trust in this philosophy, which is the very wisdom of Solomon"), misses completely the definitive contrast Ambrose sets up between Voluptas as the founder of the philosophy of pleasure (and, by implication, all merely human wisdom) and the wisdom revealed by solomon (and, by implication, all divine, scriptural wisdom).

Savon (1977b, 1:243-325) discusses Ambrose's use of the Voluptas-Virtus debate in comparison with Philo's version; the first pages $(243-6)$ trace the history of the device from its first formulation as a story about Heracles. (Also see below, chapter four, n.39.)

11 Nauroy $(1976,269)$ also makes the point that Ambrose does not distinguish between "la philosophia et la sapientia (saecularis)."

12 De Abr. 2.72-3 (CSEL 32.1, 626.1-20): "Denique sequitur quia Sara uxor Abrahae sterilis fuerat. erat autem ei ancilla Aegyptia, cui nomen Agar, quod ad ecclesiam pertinere in ea expositione, quam de moralibus scripsimus, apostolicis docuimus exemplis. ecclesia enim sterilis uidetur in hoc saeculo, quia non saecularia parturit nec praesentia, sed futura, hoc est non ea quae uidentur, sed quae non uidentur. huius ancilla est synagoga uel omnis haeresis, quae seruos, non liberos creat. ideoque Agar dicitur habitatio. etenim temporalis spem fouet, non perpetuae possessionis gratiam tenet. itaque ne insolens partu corporeo fiat ancilla eius et ius sibi ecclesiae uindicet, dicitur ibi: 'eice ancillam et filium eius; non enim heres erit filius ancillae cum filio meo Isaac.' sed 
Then it follows that Sarah, the wife of Abraham, was barren. However, there was with her an Egyptian maidservant by the name of Hagar. These things refer to the church, as we have taught, following the examples of the apostles, in the explanation which we wrote about the moral meanings [in the first book about Abraham, 1.28]. For the church seems to be barren in this world because it gives birth not to worldly things nor to things of the present time, but to things to come; that is, not to things that are seen, but to things that are unseen. The church's maidservant is the synagogue or every heresy which creates slaves, not free persons. Therefore, Hagar is called a house, for she cherishes hope of something temporal and does not grasp the grace of an eternal possession. Thus lest her maidservant, having given birth through the body, become insolent and claim for herself the right of the church, it is written there: "Throw out the maidservant and her son; for the son of the maidservant will not be heir with my son Isaac." But Sarah also exists in individual persons, as does Hagar. Sarah is true virtue, true wisdom, but Hagar is craftiness as the maidservant of more perfect virtue, for the one is spiritual wisdom, the other the wisdom of this world. Thus it is also written that Hagar is Egyptian because philosophical learning abounded in Egypt. Moses was educated in all the wisdom of the Egyptians but he threw it out, preferring disgrace for christ's name to the treasures of Egypt.

Hagar is Judaism, heresy, the flesh, worldly wisdom, and philosophy; Sarah is the simple opposite, the truth. ${ }^{13}$

etiam in singulis sarra [sic] est et in singulis Agar. Sarra [sic] uirtus uera est, uera sapientia, Agar autem est uersutia tamquam ancilla perfectioris uirtutis; alia enim sapientia spiritalis, alia sapientia huius mundi. ideo etiam Aegyptia scribitur, quia philosophica eruditio abundauit in Aegypto. denique et Moyses eruditus erat in omni sapientia Aegyptiorum, sed abiecit eam praeferens Aegypti thensauris obprobrium pro Christi nomine."

13 Ambrose depends upon Philo (QGen 3.19) for his allegorical interpretation of Sarah and Hagar but Philo takes a relatively positive view of the servant status of human wisdom, attributing to it a patient willingness to be perfected, while Ambrose alters Philo's sense by emphasizing only the stark contrast between the two figures (Madec 
In De officiis ministrorum 3.9, Ambrose, while following Cicero's discussion (De off. 3.3.11) of the virtuous and the useful, is careful to nuance his own explanation of the useful by drawing the contrast between the wisdom of the flesh, which equates usefulness with monetary value, and the wisdom of God, which values things by other than worldly standards. Elsewhere, in a passage exhorting his audience to be humble, Ambrose also notes that it is the "mind of flesh" that exalts human wisdom. ${ }^{14}$

The church, bound to Christ as a bride to her bridegroom, cannot be separated from him by persecution or fleshly temptations; nor can "philosophy ravage, Manicheans corrupt, Arians divert, or Sabellians poison" the church. ${ }^{15}$ A bit later in the commentary on luke, Ambrose again juxtaposes philosophy to heresy and

1974c, 102-3). Savon, in his study of Philo's influence on Ambrose's exegesis (1977b), does not discuss this passage from De Abraham.

14 Exp.ps. 11814.20 (CSEL 62, 310.30-311.2): "non facile potest quisquam humilitatem docere inflatus; quamuis humanam sapientiam mens carnis extollet."

Madec (1974C, 44) notes that Ambrose "condamne sous le nom de 'philosophie' la vie charnelle qui fait obstacle à la vie spirituelle."

15 Exp. evang. sec. Luc. 8.9 (CC 14, 301.90-5): "Vir Christus, uxor ecclesia est, caritate uxor, integritate virgo. Ergo quem deus traxit ad filium non separet persecutio, non auertat luxuria, non philosophia depraedetur, non Manicheus contaminet, non Arrianus auertat, non Sabellianus inficiat. Deus iunxit, Iudaeus non separet. Adulteri sunt omnes qui adulterare cupiunt fidei et sapientiae ueritatem." 
contrasts both, in their rich multiplicity of errors, to the honest poverty of the church: ${ }^{16}$

Wealthy heresy has put together many gospels, but poor faith has held to the one gospel, which it received; wealthy philosophy has fashioned for itself many gods, but the poor church has known one god.

Thus, human wisdom, the wisdom of the world and the flesh, philosophy, and heresy can all be understood as expressing the same fundamental falseness, standing over against true, divine wisdom. That contrast between human and divine wisdom is expressed in various ways in Ambrose's writings, many of which stress the gulf that exists between the creator and the creature in terms of the disparate worth and power of their homonymous attributes. For example, ${ }^{17}$

God is wisdom because wisdom is the son of God -wisdom by nature, not by practice. For the wisdom that is an excellence of God the Father is one thing, wisdom as an excellence of the soul another; the former is innate, the latter created. The wisdom that brings forth works is one thing, the work another; for it is the work of the mind to understand carefully, to perceive energetically. These works are gifts of nature, but the one who

16 Exp. evang. sec. Luc. 8.17 (CC 14, 304.197-200): "Diues haeresis euangelia multa conposuit, pauper fides hoc solum euangelium tenuit, quod accepit: diues philosophia plures sibi deos fecit, pauper ecclesia unum deum nouit."

17 Exp. evang. sec. Luc. 6.1 ( CC 14, 175.7-14): "Deus ergo sapientia est quia sapientia dei filius est, sapientia per naturam, non per profectum. Alia est sapientia dei patris uirtus, alia sapientia uirtus animae: illa nata est, haec creata. Alia sapientia auctor operum, alia opus; opus enim mentis sapere prudenter, sentire uiuaciter. Haec dona naturae sunt, operator autem non creatura est, sed creator, hoc est non naturae munus, sed munerator naturae." 
does the work is not a creature, but the creator; he is not a gift of nature, but the giver of nature.

It is not surprising then that in the Exameron, one prominent theme of which is the ineradicable distinction between creator and creation, Ambrose includes the contrast between human and divine powers of knowledge and understanding. "Who would dare claim his own knowledge to be equal to God's?"18 God and humans do not see things the same way; God sees deeply into things, human beings see only the surface. Rather than trusting our own eyes and opinions to evaluate creation correctly, we must simply hear that God saw it and said it was good; we may not then dare to consider debatable what God has already sealed with approval. ${ }^{19}$

18 Exam. 6.7 (CSEL 32.1, 208.16-7): "quis igitur aequalem sibi cum deo audet scientiam uindicare . . ."

19 Exam. 2.3 (CSEL 32.1, 43.11-7): "illo igitur, sancta plebs, eleua mentem tuam et totum animum tuum eo confer. non sic deus uidet quemadmodum homo. deus in corde, homo in facie. nec sic igitur homo uidet quemadmodum deus. audis quia deus uidit et laudauit. noli igitur tuis oculis aestimare quae facta sunt opinionibusque colligere, sed quae deus uidit et probauit ea tu retractanda non putes."

This is one of many instances is Ambrose's work where he not only metaphorically associates reason with vision -a trope common among his contemporaries, Christian and nonChristian alike -- but also contrasts seeing and hearing. seeing represents human reason (Exp. evang. sec. Luc. prol.2, De Isaac 22); hearing represents faith (Exp. evang. sec. Luc. 4.71). The limitations of human reason are like visual defects and we are led astray by them. Faith, however, is a function of hearing the Word of God, and can be relied upon. "Unless one hears what ought to be pursued, no one is supported. In the duty of hearing is the mainstay of everything" (Exp. ps. 118 15.3 [CSEL 62, 331.4-6]: "nisi enim unusquisque audierit quid sequi debeat, nemo firmatur. 
The concept "understanding" as it is generally used is not the same thing as understanding according to the Word of God, and the sort of wisdom that concerns itself with the things of this world is mere tinsel compared to true wisdom. Every philosophy errs in pursuing knowledge of the world that cannot be useful, and knows nothing of God who should be the only object of its quest. ${ }^{20}$ Thus, scripture warns us not to be too wise (EC. 7.17); like wine that inebriates when taken in excess, wisdom that is merely human requires limits so that it may not harm us (Ep. 7.5-7)

True wisdom, on the other hand, is available to human beings -- even if only partially and imperfectly -insofar as they receive christ, the power and wisdom of God." "Christ is the word and the wisdom of God;

in officio igitur audiendi omnium firmamentum est.". See also Exam. 4.1, 5; De Abr. 2.61; and De fide 2.132.

20 Exp. ps. 11822.9 (CSEL 62, 492.26-8, 493.5-9): "'secundum,' inquit, 'uerbum tuum intellectum tribue mihi.' aduerte quid postulet. non 'intellectum' generaliter dixit, sed 'intellectum secundum uerbum dei' . . . postremo circa elementa mundi est falerata magis quam uera sapientia, ut est philosophia omnis, quae aliena quaerit, cum sua nesciat, scrutatur caeli plagas, mundi spatia rimatur quae sibi prodesse nihil possunt, deum ignorat quem solum deberet inquirere."

211 Cor. 1.24: ". . . Christ the power of God and the wisdom of God." This verse, equating christ and Wisdom, is referred to frequently in Ambrose's works. See, for example, De fide 1.16, 4.43, 5.196; Exp. ps. 11811.6 ; De spir. Sanc. 2.19 ; Exp. evang. sec. Luc. 6.33 . 
blessed is the soul whom wisdom embraces." 22 Everyone who welcomes christ is wise and those who keep their eyes (i.e., their reason) trained on God receive wisdom from Christ (Ep. 37.22, 29.16). As a logical corollary, "the only person who is wise is the one who has used God as his guide to knowing the foundations of truth." ${ }^{23}$

The kinds of knowledge -- "the foundations of truth" -- that are available to the wise one led by God are suggested by Ambrose as he reflects on Abraham, the model of the proficiens: ${ }^{24}$

Thus it is proper to present the soul of the wise man in training day and night, constantly on the watch, never yielding to sleep, focused on God in uninterrupted vigils in order to understand the reality of the things that exist and to know the causes of each one. But wisdom is also the interpreter of the things to come; it knows the past and considers the future. It knows the craftiness of words and the solving of proofs; it knows signs and portents and events in time and the

22 Exp.ps. 11814.31 (CSEL 62, 318.26-7): "Christus autem idem est uerbum dei atque sapientia. beata ergo anima quam complectitur sapientia."

${ }^{23} \mathrm{Ep} .37 .29$ (PL 16, 1091A): "Quis igitur sapiens, nisi qui ad ipsa pervenit divinitatis secreta, et manifestata sibi cognovit occulta sapientiae? Solus igitur sapiens, qui duce Deo usus est ad cognoscenda veritatis cubilia. . ."

24 De Abr. 2.76 (CSEL 32.1, 628.24-629.5): "oportet igitur uiri sapientis animam die noctuque in exercitio iugi specula praetendere, numquam somno indulgentem, perpetuis uigiliis intentam deo ad conprehensionem rerum earum quae sunt et singularum causarum cognitionem. sed etiam futurorum interpres sapientia est; scit praeterita et de futuris aestimat, scit uersutias sermonum et solutiones argumentorum, signa et monstra scit antequam fiant et euentus temporum et saeculorum. non potest igitur bonus atque perfectus non esse qui hanc adquisierit, quia et omnem habet uirtutem et imago bonitatis est." 
ages before they happen. Therefore, it is not possible for one who acquires wisdom not to be good and perfect, because wisdom possesses every virtue and is the image of goodness.

The virtually personified moral perfection that is wisdom in the last clause of this passage is a reminder that the equation of Christ with wisdom is never far from Ambrose's mind, pulling him away from any temptation to linger on wisdom's more abstract intellectual attractions.

Descriptions such as this one of wisdom's intellectual prowess are very unusual in Ambrose's work. For him, the aspect of divine wisdom that is accessible to human beings and, therefore, appropriate for teaching is mostly a matter of moral guidance and biblical revelation about the nature of creation, immoveable faith in that revelation being the preferred replacement for potentially errant speculation by human reason.

Moreover, Ambrose generally assumes that the ethical and faith-engendering content of true wisdom is to be gleaned primarily from the exemplary lives narrated for us in scripture, rather than from any abstract reasoning (cf. Madec $1974 \mathrm{C}, 184-5)$. This is an epistemological point made, explicitly or implicitly, throughout De officiis ministrorum and alluded to in some fashion in most of Ambrose's treatises on various patriarchs (for example, De Jos. 1.1, De Abr. 1.2, De interpell. 1.2), and will be discussed further in chapter five. 
Given this stress on teaching by biography, a formal discussion of the characteristics of or revelations by wisdom is perhaps not to be expected from Ambrose. Epistulae 37 and 38, written to Simplicianus, Ambrose's teacher during the week in which he prepared for consecration as bishop, are rightly recognized as identifiably stoic essays on the Christian ideal of the sage, ${ }^{25}$ but their emphasis is on moral conduct and scriptural faith rather than on any more speculative knowledge that might be available to the person who welcomes the wisdom that is christ.

Although Ambrose occasionally alludes to the mind's ability, given divine guidance, to penetrate the hidden mysteries, the nature and the causes of human and divine things (see, for example, De Abr. 2.76 [n.24]; also Ep. 43.15 and De Jacob 1.4 [Chap. 2, nn.19, 27]), he remains as little interested in the speculative content of wisdom as he is in the speculative powers of reason. The hallmark passage in which Ambrose draws the clear limits of human reason (De interpel1. $1.29-31$; see $n .6$ ) ends thus: "O man, why do you wish to know the depths of wisdom, which are beyond you? 'To fear God is wisdom; to

25 Madec 1974C, 63: "Deux des lettres que lui adressa Ambroise sont des dissertations sur l'idéal chrétien du sage, fortement redevables à Philon et, par l'intermédiare de celui-ci, au stoïcisme." 
abstain from evil acts is knowledge. " 26 Possession of true wisdom by human beings is manifested in perfected moral conduct and an unswerving willingness to know only what scripture teaches.

Despite the sharpness of the contrast between human and divine wisdom, it remains true -- as chapter two has shown -- that Ambrose can often be found bestowing unqualified praise on human reason and appropriating, also without qualification, philosophical terms and formulas ${ }^{27}$ that are the result of reason's work and comprise part of the body of human wisdom. It is apparent that Ambrose did not -- and could not -- simply throw over human reason and its approximations and pretensions of sagacity. Rather, he nuances his otherwise blunt distinction between the two sorts of wisdom by explaining repeatedly how reason errs so that it ends in merely human wisdom rather than drawing closer to divine wisdom. Philosophy on the whole is, for Ambrose, the result and sign of reason's error; it is love of a false and fruitless wisdom, a love whose deviance can be explained by its root mistake.

26 De interpel1. 1.31 (CSEL 32.2, 232.17-20): "O homo, quid uis profunda scire sapientiae, quae supra uos sunt? 'timere deum sapientia est, abstinere autem a malis disciplina est. '"

27 Some of the pertinent references are De Abr. 2.29, 54 ; De Noe 1; De fide 4.48 ; Exp. ps. 1182.32 ; Exp. evang. sec. Luc. 7.139 ; De virginitate 114 . 
4. The nature and result of reason's error

a) The primary error: forgetting the source

According to Ambrose, philosophy has forgotten, or chooses to ignore, its true origins in scripture and, ultimately, in God the creator. Plato, for example, although he never acknowledged it, acquired his considerable wisdom by reading, or being taught, the works of Moses and the prophets during an extended trip to Egypt (Exp. ps. 118 18.4, De Noe 24).

It is a common assertion among early Jewish and Christian writers (Madec 1974C, 29-30 and throughout; cf. Dihle $1982,5-8$ ) that whatever truth philosophy can offer has been borrowed from scripture; that claim is also a two-edged sword. It is a means of disparaging and even dismissing philosophy as a fraud in favor of a genuine wisdom based explicitly in scripture, but it is also a way to justify the acceptance and use of philosophy's truths. Ambrose's statement in De bono mortis perhaps summarizes this stance best: "Those things which are superior in the writings of the philosophers are ours." ${ }^{28}$ shifting ownership of superior thoughts from philosophy to "us" effectively diminishes philosophy as a rival but it also keeps intact and inhabitable the intellectual property whose deed has been reclaimed.

28 De bon. mort. 51 (CSEL 32.1, 747.8-9): "nostra sunt itaque quae in philosophorum litteris praestant." 
The frequency with which Ambrose mentions this notion of borrowing is surely significant (cf. Madec 1974c, 823); references to such plagiarism comprise over one-third of the 184 passages referable to philosophy and philosophers culled from the bishop's writings by Madec.

It should be noted at this point that, although much of what Ambrose says about philosophy's finding its truths in scripture is compatible with the language of borrowing and plagiarism, a clearer understanding of his conviction that scripture is the origin of those philosophical truths brings the commonly-used borrowing metaphor into question. To say that philosophy "borrows" from scripture implies the existence of a definable philosophical school or tradition which, from time to time, dipped into scripture for ideas which it now claims as its own. Ambrose's understanding would seem to be more that philosophy, as an aberrant way of life in contrast to the Christian way of life, actually arose from scripture as did Christianity, but then immediately went astray (see the discussion of De Cain 1.4 below), retaining vestiges of its originating scriptural truths while no longer recognizing their provenance. Metaphors expressing philosophy's original rooting in scripture may come closer than the borrowing metaphor to encompassing Ambrose's beliefs about worldly wisdom's debt to scripture and to the creator. 
Moreover, in most of the multiple citations amassed by Madec, the charge of plagiarism is mentioned as a means not primarily of criticizing philosophy nor of comparing it unfavorably with christian thought but of claiming the philosophical notion for Christian use. The dictum "Know thyself" came not from Pythian Apollo but from Solomon and Moses (Exam. 6.39, Exp.ps. 118 2.13; cf. Courcelle 1974, 1:113-25). The wise of the world got their scheme of four principal virtues from "us" (De par. 14). Scripture is the source of the supposedly stoic idea that all things belong to the wise (De Abr. 2.37). Each of these statements, and many others like them, is a simple reclamation of a philosophical idea judged to be true; the idea is then used for Ambrose's exegetical or pedagogical purposes without the inclusion of any other argument against philosophy's use of the notion in question.

At other times, Ambrose is more critical. For example, 29

I have used the writings of Esdras [concerning the resurrection of the dead] so that the gentiles may know that what they admire in books of philosophy has been transferred from ours. If only they had not mixed additional and harmful things in with them, as when they say that the souls of human beings as well as beasts are held in common, and

29 De bon. mort. 45 (CSEL 32.1, 741.16-21): "sed Hesdrae usus sum scriptis, ut cognoscant gentiles ea quae in philosophiae libris mirantur translata de nostris. atque utinam non superflua his et inutilia miscuissent, ut dicerent animas hominum pariter ac bestiarum esse communes earumque summum praemium, si magnorum philosophorum animae in apes aut luscinias demigrarent . . ." 
that it is their highest reward if the souls of great philosophers migrate into bees or nightingales...

Savon avers, in reference to another such critical statement by Ambrose, that this is the bishop's polemical scheme: the philosopher is reproached for having added a contrary sense to the plagiarism. 30

Comparisons that put philosophy in the inferior position -- as falling short of the original in its use of the borrowed material -- abound. Scripture is simpler than philosophy and, consequently, more pleasing (De Noe 24, De Abr. 2.70). Christianity is better at producing faithful virgins than Pythagoreanism (De virginibus 1.1719). Paul's reflections on death are better than the ones put forth even by those who define philosophy as a meditation on death (De exc. frat. 2.35). The prophets know better than the wise of this world (De fide 1.30). And, returning to his reliance on teaching by biography, Ambrose declares that Abraham's life has more to teach us than do the abstract constructs of philosophers: if Plato himself, "prince of philosophers," could write his Republic about citizenship and government in a purely

30 Savon 1977b, 1:152: "C'est le schéma polémique utilisé par Ambroise: le philosophe est accusé d'avoir joint le contresens au plagiat." 
fictious realm and if Xenophon could write hypothetically about teaching wisdom in Cyropaedia, ${ }^{31}$

so that from the deepest heart of philosophy might arise the education of a just and wise king, how much more ought we to survey even more eagerly not the made-up figure of a wise man but an image of virtue that is concrete and educated by divine teaching, and to follow in the ways of the one whom Moses described in this fashion so that he might, in a way, look behind himself [to see us following him ].

The source which philosophy has forgotten, to its considerable disadvantage, is not only the wisdom revealed in scripture but the fundamental truth of divine creation. As Ambrose says succinctly to the. Jews and, by implication, to philosophers: "How can you who deny the author of knowledge possess the key to knowledge?" ${ }^{32}$ This most damning sign of philosophy's rootlessness is given clear expression in Ambrose's interpretation of the

31 De Abr. 1.2 (CSEL 32.1, 502.2-16): "nam si sapientes mundi huius, id est et Plato ipse princeps philosophorum non ueram aliquam, sed fictam et adumbratam sibi eam quam legimus politeian proposuit persequendam, ut doceret qualem rem publicam esse oporteret, atque ita quam nec audierat nec uiderat in aliqua urbe describendam putauit, ut ii quibus hoc munus est quemadmodum rem publicam regerent institui possent, et si condiscipulus Platonis Xenophon ille Socraticus fictis et ipse rebus personam uoluit informare sapientis in eo libro quem Kyrou paideian scribit, ut ex intimo philosophiae sinu regis iusti et sapientis disciplina procederet, quanto magis nos non conpositam figuram sapientis uiri, sed expressam uirtutem et diuino institutam magisterio recensere intentius et uias eius debemus persequi, quem Moyses ita descripsit, ut retro quodammodo se ipse respiceret."

32 Exp.ps. 118 . 8.60 clauem potestis habere auctorem?"

(CSEL 62, 189.6-7): "quomodo enim scientiae qui scientiae negatis 
relationship of Cain and Abel, a reading which he in his turn has borrowed from Philo (Savon 1977b, 1:107) and which once again reveals the bishop's either/or doctrinal dualism: ${ }^{33}$

There are, therefore, two schools of thought represented by the names of the two brothers, which are opposites and in conflict with each other. One credits everything to its own mind as the source and what one might call the creator, so to speak, of every thought and sensation and emotion; that is, it ascribes all devisings to human ability. The other defers to God as the maker and creator of all things and subjects everything to God's governance as to that of a parent and guide. The former school is signified by cain; the latter is called Abel. One soul gave birth to these two schools of thought and thus they are full brothers, having come from one womb. But they are opposites who should be divided and separated once they have been brought forth as offspring of that soul, for it is not possible for conflicting factions to exist forever in one lodging.

That the two schools of thought are, in fact, "full brothers," despite their immediately divisive opposition, also has important implications for Ambrose's attitude towards philosophy, as will be discussed.

33

De Cain 1.4 (CSEL 32.1, 340.8-19): "Duae itaque sectae sunt sub duorum fratrum nomine conpugnantes inuicem et contrariae sibi, una quae totum menti suae deputat tamquam principali et quasi cuidam cogitationis et sensus et motus omnis auctori, hoc est quae omnes inuentiones humano adscribit ingenio, altera quae tamquam operatori et creatori omnium deo defert et eius tamquam parentis atque rectoris subdit omnia gubernaculo. illa prior Cain significatur, haec posterior Abel dicitur. has duas sectas anima una parturit et ideo germanae habentur, quod uno fundantur utero, sed contrariae sunt, quia oportet eas, cum quodam animae partu editae fuerint, diuidi ac separari; conpugnantibus enim hospitium esse unum perpetuo non potest." 
Ignorance of the truth of creation leads merely human wisdom to draw absurd conclusions about the world, such as attributing to the created universe or to unformed matter the sort of uncreated eternity of existence that can be true only of the one who creates and shapes matter (Exam. 1.2, 2.2; cf. Madec 1974C, 29 n.29). The first paragraphs of the Exameron are focused on the result for philosophical reasoning of its unwillingness to accept the truth of divine creation: fruitless disputations about the world's origin. The opinions that do battle in those debates are easily confounded by the simple truth revealed by God through Moses. Ambrose's approach to the first verse of Genesis thus encapsulates his primary arguments against the wisdom of the world: it has cut itself off from the true and uncomplicated revelation in scripture of the unity and power of God, the one creator, and it is therefore lost in idle speculations and pointless discussions that, because they are.rootless, can come to no good end.

b) The result of the error

It is the dialectics of philosophy, the disputationes, for which Ambrose reserves his most contemptuous remarks. ${ }^{34}$ Even dogs can achieve by nature

34 Holte $1962,148 \mathrm{n.2}$ : "Le terme latin pour désigner la dialectique est disputationes disciplina." Not only Christian writers castigated philosophy for its "excessive 
and without apparent difficulty the kind of "reasonable" conclusions that philosophers dedicate their lives to sorting out in syllogisms and endless discussions, and a dog has the additional good sense to recognize and adore its master (Exam. 6.23). What passes for clarity of vision in the worldly wise, when compared with the illumination offered by Christ, is no more than the blindness of the owl when confronted with the light of day $:^{35}$

I speak of the inner eye which the wise of the world possess, yet they do not see; they discern nothing in the light; they walk in the dark . . . Having beside them the daylight of christ and the lamp of the church and seeing nothing, they open their mouths as if they know everything. They are intelligent about useless things, stupid about eternal matters, and in the prolixity of their lengthy disputations they disclose the blindness of their own knowledge. So, while they long to flutter about in their fine discourses, like the owl they vanish in the light.

The opinions of philosophers are easily refuted when opposed by opinions which, because they follow the traditions of scripture, more nearly approximate the truth (Exam. 2.9-10; cf. De Noe 92). Moreover, as emphasized

subtleties" in dialectical pursuits; see, for example, Seneca's scorn of captiosae disputationes (Ep. mor. 45.5; Madec 1974C, 49 n.142).

35

Exam. 5.86 (CSEL 32.1, 200.11-3, 16-21): "de cordis oculis loquor, quos habent sapientes mundi et non uident, in luce nihil cernunt, in tenebris ambulant.. . habentes in proximo diem Christi et lumen ecclesiae et nihil uidentes aperiunt os quasi scientes omnia, acuti ad uana, hebetes ad aeterna et longae disputationis anfractu prodentes scientiae propriae caecitatem. itaque dum cupiunt subtilibus uolitare sermonibus, quasi noctuae in lumine euanuerunt." 
earlier, the inanity of speculation is a direct consequence of turning away from the certainties of scriptural revelation. The Arians, for example, by following Aristotle rather than the apostles, have abandoned the wisdom of God and have chosen instead the snares of disputation and dialectics (Exp.ps. 118 22.10). Even when an argument with the wisdom of the world is not his primary focus, Ambrose often casts glancing blows at the foolishness of indulging in dialecticis disputationibus philosophorum. ${ }^{36}$

Furthermore, disputations are as dangerous in their power to bar the way to true wisdom as they are useless to light the way to that goal. The groves of that other school of thought, the one that is ignorant of its creator, are where "truth is overshadowed and an unrestricted vision of heavenly knowledge is obscured by the dreadful darkness of disputation." ${ }^{37}$ And, at times, the danger in dialectics lies not just in its ability to

36 For example, Exam. 3.7 (CSEL 32.1, 63.7-13): "adstipulantem nobis lectionis seriem testificamur, quae aperte probat post congregationem aquae, quae erat super terram, et post deriuationem eius in maria apparuisse aridam. desinant ergo nobis dialecticis disputationibus mouere negotia dicentes: quomodo terra inuisibilis, cum omni corpori naturaliter species et color insit, omnis autem color sit subiectus aspectui?"

See also De Abr. 2.23 ; Exp. evang. Sec. Luc. 2.42 ; De off. min. $1.116,2.49 ;$ De fide 4.46 .

37 De Cain 1.44 (CSEL 32.1, 375.24-5): "quibus obumbratur ueritas et quidam liber caelestis uisus cognitionis horrore tenebrosae disceptationis absconditur." 
entangle the would-be proficiens in ignorant mind games but in its sheer wrongness.

In most of the instances in which Ambrose disagrees with philosophy's conclusions, he uses a formula, "they say . . but we say," without including in the contrast much in the way of explicit condemnation or refutation of philosophy's opinion. He is often content simply to disagree with and thereby dismiss philosophy's hypothesis. ${ }^{38}$ Occasionally there is not even an implicit refutation, but simply a preference for the language and style of the point as grounded in scripture and christian tradition. ${ }^{39}$

In a few passages, however, Ambrose takes philosophy to task for putting forth ideas that are not only incorrect but evil. Most of his ire in this regard is reserved for the moral principle that pleasure is the highest good and justifies any pursuit of earthly lusts and luxuries, ideas at times specifically associated with the name of Epicurus (Ep. 63.8-21; De Cain 1.14). Just like carnal desire, philosophy is one of the dangerous snares of this world (Exp. evang. sec. Luc. 4.10), and philosophy's involvement with mundane things taints its works by limiting its notion of reward to pleasure only

38 See, for example, Exam. 1.6; De Abr. 2.58, 85; De off. min. $1.27-9,3.27$; Ep. 45.15 .

39 See, for example, De off. min. 3.29-36 and Ep. 44.3 . 
(De virginibus 3.19). On the doctrinal level, only the theory of metempsychosis seems equally capable of stirring Ambrose to a passionate denunciation of philosophical error in place of his usual cool or briefly disparaging dismissal (De exc. fratr. 2.126-131; cf. De bon. mort. 45) .

Beyond these infrequent references to the dangerous moral or doctrinal wrong-headedness of some philosophical thought, there is another way in which worldly wisdom is seriously in error that is far more important to Ambrose, at least judging by the attention he gives it. Philosophy and its practitioners, the wise of the world, overreach themselves. They seek impossible or forbidden knowledge and even, at times, succumb to the illusion that they have discovered a wisdom that is, in fact, beyond them. That is, philosophers err in not recognizing and accepting the limitations of human reason described earlier in this chapter.

They seek to know the summum bonum, which is undoubtedly beyond human understanding (De Isaac 79); they trouble themselves over useless attempts at cosmological calculations, like those concerning the earth's position in the universe (Exam. 1.22) or the movements of the sun and stars (De exc. fratr. 2.86). Philosophers are the foolish ones who, ignorant of God's advice to Job (Job 28.14 ; cf. De interpel1. 1.29-31), persist in seeking 
wisdom in the abyss, thinking "that they can know its depths on their own and by their own ability. 40

Human wisdom's fault is its lack of humility, its unwillingness to acknowledge and seek out God's wisdom rather than its own feeble attempts at knowledge, preferring its rootless disputations and inescapable errors to the truth revealed in scripture. This lack of humility makes it impossible for philosophers to know themselves, much less the nature of the universe (Exp. ps. 118 10.20), and is the reason that God reveals divine truth to the "little ones" rather than to the wise of the world. ${ }^{41}$

Philosophy's error, then, is in being too proud -and, perhaps, too ignorant -- to admit its source in scripture, its dependence upon the creator. As the result of the fundamental mistake of separating itself from its only nourishing root, worldly wisdom cannot help but become lost in its own vain dialectics, entangled in conflicting and false opinions, susceptible to the seductions of moral evil and cognitive error, and incapable either of seeing the truth or of using the true

40 De interpell. 2.23 (CSEL 32.2, 247.14-6): "non in abysso eam [sapientia] quaerat sicut philosophi, qui arbitrantur quod ipsi sua sponte suo ingenio profunda eius possint cognoscere . : ."

41 Exp. evang. sec. Luc. 7.65 (CC 14, 236.671-3): "Postremo aperit caeleste mysterium, quod placuerit deo ut paruulis magis quam prudentibus istius mundi suam gratiam reuelaret . . ." 
ideas it has actually gleaned from scripture as lanterns along the path to genuine wisdom. Having divorced itself from its true foundation, philosophy is lost on the dark and hopeless path of its own imaginings, seeking an illusory end.

Therefore, human wisdom is powerless to save us, to bring us at last to true wisdom in the bosom of the Father. Philosophy is to be shunned for its power to deflect us from the route of salvation, as Paul warned in Colossians 2.8 , for "it was not by dialectics that it pleased God to save his people, for the kingdom of God exists in the simplicity of faith, not in verbal disputes." 42 What the church offers is not the mathematical and astrological speculations of philosophy, but the true mystery that salvation comes only through the

42 Col. 2.8: "See to it that no one takes you captive through philosophy and empty deceit, according to human tradition, according to the elemental spirits of the universe, and not according to christ."

De fide 1.42 (CSEL 78, 18.29-31): "Sed non in dialectica conplacuit deo 'salvum facere populum suum'; regnum enim dei in simplicitate fidei est, non in contentione sermonis." 
resurrected Christ. ${ }^{43}$ As Ambrose says at the end of the first sermon on the six days of creation, ${ }^{44}$

Therefore, let us leave these philosophers, who refute themselves in mutual disputations, to their debates. Sufficient for our salvation is not the controversies of dialectics but the truth of the commands, not the cleverness of argumentation but the faith of the mind, so that we may serve the creator rather than the creature, the creator who is God, blessed through the ages.

43 De Abr. 2.80 (CSEL 32.1, 632.17-23): "ideoque non cybos geometricae nec tetragonum numerum philosophiae nec confessionem ut aiunt Pythagoricam nec semper uirgines ut appellant ebdomadis numeros cura discutimus inani nec mundum radio formamus nec caelum in puluere quaerimus nec intra angustos abacos orbem concludimus, sed uera aperimus mysteria, unam salutem esse Christi resurrectionem."

44 Exam. 1.24 (CSEL 32.1, 22.24-23.3): "itaque illos suis relinquamus contentionibus, qui mutuis disputationibus se refellunt: nobis autem satis est ad salutem non disputationum controuersia, sed praeceptorum ueritas nec argumentationis astutia, sed fides mentis, ut seruiamus creatori potius quam creaturae, qui est deus benedictus in saecula." 


\section{CHAPTER FOUR \\ CHRISTIAN WISDOM}

According to Ambrose, as he explains in his book on Abraham, it is characteristic of the best mind to meditate continually on the beginning and the end, that from which the mind proceeds and to which it tends. The beginning and the end are the good and they are also wisdom. So that we may recognize that our good and, consequently, our wisdom are in our congruence with the beginning and the end, Jesus has told us that he himself is Alpha and Omega, principium et finis. ${ }^{1}$

Ambrose's interest in this language of beginning and end emerges also in his commentary on Psalm 119. There, in addition to references to Christ as the telos, ${ }^{2}$ he uses the related idea of Christ as the fulfillment of the law to work a virtual identification of christ, law, and beginning. His purpose in this instance is to castigate

1 De Abr. 2.21 (CSEL 32.1, 579.14-21): "hoc esse mentis optimae, meditari semper principium et finem, eo procedere et inde egredi, hoc esse bonum. bonum autem sapientia est; 'nemo enim bonus nisi unus deus.' ab eo procedimus creati pēr ipsum, ad eum reuertimur, quia 'cum Christo esse multo melius.' et ut scias quia bonum est congruere principium et finem, ipse ait bonus dominus Iesus: 'ego sum $A$ et $\Omega$, principium et finis.'"

2 Exp.ps. $1185.23,12.45,12.48$. In 12.45 , Ambrose explains that in Latin telos is translated as finis and consummatio and that these two senses are both present in the idea of Christ as telos, because christ is both finis legis and the one who said, "ecce ego uobiscum sum usque ad consummationem saeculi" (CSEL 62, 277.22-278.3). 
heretics who refuse to accept the law revealed in the Hebrew scripture; he states that even though they claim to hold to Christ, they cannot possess that end because, by refusing the law, they do not hold the beginning, and Jesus is the beginning and the end. ${ }^{3}$

As discussed in chapter three, the fundamental error of merely human wisdom lies in its ignorance, whether wilful or not, of its beginning; the ineluctable result of that error is that worldly wisdom must forever strive for mistaken or ephemeral or unattainable ends. ${ }^{4}$ The key to the divine wisdom available to the christian lies instead in the believer's constant recognition that the only possible beginning and end for human reason is christ, the wisdom and power of God. The identification of Christ with wisdom and the essential connection between the source and the goal are the two themes that ground both

3 Exp.ps. 1185.24 (CSEL 62, 94.15-20): "Aduertimus igitur, quantum nobis ambulandum sit, ut ueniamus ad Christum, ambulandum in lege, quia finis legis est Christus. sine lege ergo non peruenitur ad Christum. unde manifestum est quod haeretici, qui legem ueteris non accipiunt testamenti, etsi dicant quod Christum teneant, tamen tenere non possunt finem, qui initium non tenuerint. ipse est Iesus initium et finis."

4 Moreover, in reference to Ambrose's pejorative association of disputations with philosophy (see chapter 3 , pp.109-12), it is worth noting that he identifies the Word of God as the end of debate, as the "apotelesma, the delimitation and completion of disputation, which is given to those who are more prudent and settles doubts" (Ep. 8.5 [PL 16, 913B]: "Verbum ergo Dei apotelesma est, id est, definitio et consummatio disputationis, quod infunditur prudentioribus, et dubia confirmat"). 
Ambrose's depictions of Christian wisdom and his understanding of the failure of worldly wisdom.

\section{The true source}

\section{a) Timor domini}

Ambrose reminds his hearers and readers often that it is the fear of the Lord that is the beginning of wisdom (Ps. 111.10, Pr. 9.10). ${ }^{5}$ The citation frames the invocation of humility with which he introduces De officiis ministrorum (1.1) and, later in the same work, anchors his assertion that faith is both primary and integral to wisdom (1.252). In De Jacob (1.9), fear of the Lord is one of the virtues because it initiates wisdom and is the route by which godly teaching is received. once again joining the beginning and the end, Ambrose teaches in his commentary on Psalm 119 that those who fear God are not only wise but blessed, an adjective which, for Ambrose, uniformly implies eternity (Exp. ps. 118 8.1).

However, elsewhere in Expositio psalmi CXVIII, in an exegesis of verse 38 ("Confirm to your servant your

5 On occasion, when he is speaking of virtues, the maxim takes another form: piety towards God is the beginning of understanding (De off. min. 1.126 , Exp. ps. 118 18.45). In each instance, piety is called the foundation of all virtues and understanding is the ability to carry out virtuous duties. 
promise, which is for those who fear you"6), Ambrose expands on his use of the proverb by denying that one can approach wisdom by the fear of God alone, without concomitant efforts both to shun the world and to obtain knowledge: ${ }^{7}$

The prophet says that fear of the Lord is the beginning of wisdom. But what is the beginning of wisdom if not renunciation of the world, since to know the things of the world is foolishness? Thus the apostle says that the wisdom of this world is foolishness before God. But even the very fear of God, unless it is in accordance with knowledge, produces nothing; on the contrary, it is particularly harmful. Even supposing that the Jews have a fervor for God, yet because they do not have

6 This is the NRSV translation; Ambrose's version of verse 38 is "statue seruo tuo eloquium tuum in timore tuo" (Exp. ps. 1185.37 , CSEL 62, 102.12-3). For discussions of the scriptural texts available to and used by Ambrose, see Muncey (1959) and Frede (1976).

7 Exp. ps. 118 5.37-8 (CSEL 62, 102.13-103.5, 15-6): "initium esse sapientiae timorem domini dicit propheta. quod est autem initium sapientiae nisi saeculo renuntiare, quia sapere saecularia stultitia est? denique sapientiam huius mundi stultitiam esse apud deum apostolus dicit. sed et ipse timor domini, nisi secundum scientiam sit, nihil prodest, immo obest plurimum; siquidem Iudaei habent zelum dei, sed quia non habent secundum scientiam, in ipso zelo et timore maiorem contrahunt diuinitatis offensam. quod circumcidunt infantulos suos, quod sabbatum custodiunt, timorem dei habent; sed quia nesciunt legem spiritalem esse, circumcidunt corpus, non cor suum, ignem sabbato adolere formidant, cum lex sanctificationis die libidinum ignem prohibeat accendi.

Et quid de his dicam? sunt etiam in nobis qui habent timorem dei, sed non secundum scientiam, statuentes duriora praecepta, quae non possit humana condicio sustinere. timor in eo est, quia uidentur sibi consulere disciplinae, opus uirtutis exigere, sed inscientia in eo, quia non conpatiuntur naturae, non aestimant possibilitatem. non sit ergo inrationabilis timor. etenim uera sapientia a timore dei incipit nec esse sapientia spiritalis sine timore dei; ita timor sine sapientia esse non debet. . . . plenus enim disciplinae timor non nutat ad lapsum." 
it in accordance with knowledge, in that very fervor and fear they incur a greater offense against divinity. Insofar as they circumcise their infants, insofar as they keep the sabbath, they fear God. But, because they do not know that the law is spiritual, they circumcise the body and not their own hearts; they dread burning a fire on the sabbath although the law prohibits kindling the fire of passion on the day of sanctification. And why should I speak of these things? Even among us there are those who fear God but not in accordance with knowledge, those who establish ever harsher rules which it is not possible for the human condition to bear. There is fear in that, because they seem to themselves to consider the teachings and to carry out the work of virtue. But there is also a lack of knowledge in it, because they neither experience nor think about the potential of nature. Therefore, do not let fear be irrational. For true wisdom begins in the fear of God and there is no spiritual wisdom without the fear of God; thus there should be no fear without wisdom. . . Fear that is full of learning does not give way to error.

Later in that work (in his discussion of verse 75: "I know, o Lord, that your judgments are right, and that in faithfulness you have humbled me" ${ }^{8}$ ), Ambrose further limits the status of fear in the route to wisdom, associating fear with faith, knowledge with wisdom: ${ }^{9}$

8 Again, the NRSV translation; Ambrose's Latin is "agnoui, domine, quoniam iustitia iudicia tua, et in ueritate tua humiliasti me" (Exp. ps. 118 10.28, CSEL 62, 220.10-1).

9 Exp.ps. 11829,31 (CSEL 62, 221.10-5, 222.6-14, 1720): "accepta est ergo intellectus et cognitionis gratia, agnouit iusta dei esse iudicia. agnoscere autem perfecti est. denique aliud est credere, aliud agnoscere: fides timentis, agnitio sapientis. qui enim timet, rationem non quaerit, sapiens autem et agnitionem eorum inuestigat quaecumque percipere desiderat. . . .

Distat igitur inter cognoscere et timere, ut eo reuertamur. denique euangelii lectio docere nos debet; ait enim dominus ad eos, qui credebant ei ex Iudaeis: 'si manseritis in uerbo meo, cognoscetis ueritatem et ueritas 
He [the psalmist] has received the grace of understanding and knowledge; he knows the judgments of God to be just. But, to know is characteristic of one who is perfect. Of course, to believe is one thing, to know another; faith is for the one who fears, knowledge for the wise one. The one who fears does not seek reason, but the wise one searches out knowledge of all sorts of things and wishes to understand them. . . Therefore, there is a difference between knowledge and fear, so that we may return to our subject. So the reading of the gospel should teach us, for the Lord said to those from among the Jews who believed in him, "If you abide in my word, you will know the truth and the truth will free you." "If you abide," he says, "you will know." You see that someone who, fearing God, heard his word would not be able to know straight from the beginning. Not only are fear and knowledge not the same thing, but in fact even faith and knowledge are not the same; as the apostle taught, there are different gifts of grace. . . So if one is given faith and another knowledge, you see that where there is faith there is not immediately also knowledge. But where there is knowledge there is both faith and prudence, nor can we separate diligence from them.

In yet another turn on the proverb that locates the beginning of wisdom in the fear of the Lord, Ambrose returns to the beginning and end theme by contrasting fear as wisdom's beginning with love as the fullness of wisdom. And, in a parallel statement, he asserts that faith is the beginning of a Christian, but justice is the Christian's

liberabit uos.' 'si manseritis,' inquit, 'cognoscetis.' uides quia non a principio potuit cognoscere quicumque timens deum uerbum eius audiuit. non solum autem non idem est timor et cognitio, uerum etiam non idem est fides et cognitio, siquidem etiam apostolus docuit diuersa munera gratiarum. - . si ergo alii fides datur, alii cognitio, uides, ubi fides, non statim cognitio, ubi autem cognitio, et fides est et prudentia nec ab eo diligentiam possumus separare." 
fullness. ${ }^{10}$ This return to a moral emphasis, away from talk of undirected knowledge, is found also in Ambrose's reference to the proverb in the Exameron. There, in a paragraph devoted to various senses of principium, he ends with a moral lesson: ${ }^{11}$

There is also a beginning of good learning. As it is written, "The fear of the Lord is the beginning of wisdom," because those who fear the Lord avoid error and direct their own ways along the path of virtue. For unless one fears God, one is not able to renounce sin.

This equation of wisdom's beginning with entering sinless ways is another reminder that, for Ambrose, wisdom -- like reason -- is primarily a moral concept, as is also evident in the citation from Expositio psalmi CXVIII 5.38 given above (n.7), where knowledge is required so that fear may stimulate actions that truly "carry out the work of virtue."

10 Exp.ps. 118 20.56-7 (CSEL 62, 472.23-473.2, 13-5): "sicut enim 'initium sapientiae timor domini," plenitudo autem sapientiae dilectio -- lex enim sapientia, plenitudo autem legis dilectio --, ita plenitudo uerborum dei sapientia cognitioque iustitiae. namque sicut a timore domini processus quidam est ad gratiam caritatis, ita a ueritate ad iudicium iustitiae diuinae quidam uidetur fieri processus. . . fides principium christiani est, plenitudo autem christiani iustitia est; fides in confessione populorum, iustitia in martyrii passione."

11 Exam. 1.12 (CSEL 32.1, 10.22-11.1): "est etiam bonae principium disciplinae, sicut est illud: 'initium sapientiae timor domini,' quoniam qui timet dominum declinat errorem et ad uirtutis semitam uias suas dirigit. nisi enim quis timuerit deum, non potest renuntiare peccato."

Pepin (1976) analyzes the meanings of principium as Ambrose uses the word in the first book of his Exameron. 


\section{b) Verbum dei}

The source of the knowledge that fills fear and faith with learning so that they do not give way to error is God and, more specifically, God's word: both the word of God in scripture and God the Word, the Christ. Ambrose often plays on the two senses of verbum such that, at times, it is unclear whether he refers to the written or the incarnate word of God, and likely that the ambiguity is intentional. For example, part of his commentary on Psalm 119.17 ("Restore your servant; I shall live and shall keep your words"12, is a discussion of why "words" is plural. The explanation centers around the idea that multiple verba, specifically those denoting virtues like justice, chastity, and piety, are all subsumed in the one verbum, identified as Christ, in whom "we are participants according to our ability." In this case, then, the verba which the psalmist promises to keep are both virtuous precepts and characteristics of the Word, to whom the psalmist is, therefore, also declaring himself to adhere. Any confusion between the two interlocking senses of verbum in this passage is reconciled by the reminder that

12 This is a direct translation of Ambrose's Latin: "retribue seruo tuo; uiuam et custodiam uerba tua" (Exp. ps. 118 3.10, CSEL 62, 46.6-7). The NRSV translation gives "verba tua" in the singular and thus eliminates the stimulus for Ambrose's exegesis. 
the "spirit of wisdom" includes all the verba and is the verbum. 13

Ambrose's consistently attentive and deliberate use of the word verbum calls into question the decision by Tissot, in one passage of his sources chrétiennes translation of Ambrose's commentary on Luke, to render verbum as 1 'intelligence because he considers verbum in this instance to denote the Greek logos. The subject of the passage is the veracity of the writers of the gospel. Ambrose writes, ${ }^{14}$

13 Exp. ps. 1183.20 (CSEL 62, 51.22-52.18): "Neque te moueat, quod ait, 'multa uerba custodiam,' quia, cum unum uerbum cognouerit, multa uerba cognoscit. in uno multa sunt et in multis unum est. probandum est igitur, quomodo unum uerbum multa sint et multa uerba unum uerbum sit. nec difficile doceri, cum dixerit apostolus, quia 'ipse est imago dei inuisibilis, primogenitus omnis creaturae, in quo creata sunt omnia in caelestibus et in terra, siue uisibilia siue inuisibilia, siue sedes siue dominationes siue principatus siue potestates; omnia per ipsum et in ipso creata sunt.' unum est igitur uerbum quod operatur in singulis, et cum in singulis operatur, operatur omnia et in omnibus. hoc uerbum unicum apud patrem se diffudit in plurima, quia de plenitudine eius omnes accepimus. itaque si uideas singula omnium, quae creata sunt in ipso, uidebis in singulis unum uerbum esse omnium, cuius pro captu nostro participes sumus. in me uerbum est humanum, in alio uerbum caeleste, uerbum angelorum in plerisque, sunt qui habent uerbum dominationum et potestatum. uerbum est iustitiae, uerbum castitatis, uerbum prudentiae, uerbum pietatis, uerbum etiam uirtutis. sic unum uerbum multa sunt et multa uerba unum sunt. 'nec uero arduum est istud aestimari, cum legerimus, quia omnia potest spiritus sapientiae."

14 Exp. evang. sec. Luc. 1.4 (CC 14, 8.51-4, 57-8): "quoniam non signis et prodigiis, sed uerbo uera et falsa discriminant qui salutaria domini gesta describunt uel qui animum mirabilibus eius intendunt. . . . Ita uerbo atque ratione, non signis fides nostra fundatur."

Tissot's translation of this passage (1971, 1:48) reads: "car ce ne sont pas les miracles et les prodiges, 
it is not by signs and portents, but by the word that those who describe the saving acts of the Lord or who direct their thoughts to his wondrous deeds separate true things from false. . . In the word and in reason, and not in signs, let our faith be rooted.

The contrast Ambrose draws between signis and verbo certainly could suggest that verbo refers to an analytic function of reason but, given both Ambrose's frequent references to Christ as the Word and the absence of other instances -- or citations by Tissot -- in which verbum could reasonably be thought to substitute for logos, intellectum, or ratio, it seems more likely that in this case Ambrose means precisely that it is because of their reliance on Christ that the evangelists can discern the truth about Jesus' 1ife. Moreover, Ambrose spends the next three sections of his commentary (Exp. evang. sec. Luc. 1.5-7) explaining that, when Luke 1.2 speaks of the witness of "ministers of the word [logos]," the word in question is not the spoken word but the Word made flesh. 15

c'est l'intelligence qui fait discerner le vrai du faux à ceux qui racontent ce que le seigneur a fait pour notre salut ou qui appliquent leur coeur à ses merveilles. . . . Ce sont donc l'inteligence et la raison, non les miracles, qui servent de base à notre foi."

In a footnote, Tissot explains his choice of "1'intelligence" thus (1:48 n.1): "Tel est, croyons-nous, le sens qu'il faut donner ici a verbum; on le rencontre parfois pour le grec logos, dont verbum est la transposition."

15 of interest in relation to the idea that through the Word the evangelists can differentiate truth and falsehood, is this statement from De Paradiso which, by Palanque's 
When Ambrose wishes to make a clear distinction between words as language and the Word as Christ, he generally uses verbum nostrum or sermo for spoken or written discourse. In De fide 4.72-74, he contrasts the expressive but only indirectly efficacious utterances of human beings (verbum nostrum) with the living, working, healing power of the Word (verbum dei). Creation through the Word is a recurring theme in Ambrose's writings but, at one point in the Exameron, he identifies not the verbum but the sermo dei as "the power of nature and the enduring quality of matter." That here sermo is not intended to connote Christ the Word is suggested by the context, which stresses God's creation by command, including the immediately subsequent citation of Psalm 148.6 in which God is praised for establishing nature by decree (praeceptum).$^{16}$

tentative reckoning $(1933,529-36)$, may have been written about the same time (377) as the first book of the luke commentary: "Not by the ears of the body do we make judgments about heavenly commands, but when the Word of God is present certain opinions about what is good and what is evil arise in us" (De par. 39 [CSEL 32.1, 296.4-6]: "non enim auribus corporis de mandatis caelestibus iudicamus, sed cum esset dei uerbum, opiniones quaedam nobis boni et mali pullulauerunt. . "). See also Exp. ps. 118 11.20.

16 Exam. 2.10 (CSEL 32.1, 48.12-4, 16-9): "audio firmamentum fieri praecepto, quo diuideretur aqua et ab inferiore superior discerneretur. . . . sermo dei uirtus naturae est et diuturnitas substantiae, quoad uelit eam manere qui statuit, sicut scriptum est: 'statuit ea in saeculum et in saeculum saeculi; praeceptum posuit, et non praeteribit." " 
In a notable passage in De bono mortis $(19-21)$,

Ambrose limns both the distinction and the close relation

between scriptural discourse (sermo) and God the Word

(deus verbum) as he describes a garden banquet in the song

of Solomon (5.1-2) which he believes inspired Plato's

Symposium: ${ }^{17}$

17 De bon. mort. 20-1 (CSEL 32.1, 721.18-723.14): "Unde ait sponsus - sponsus autem animae deus uerbum est, cui anima legitimo quodam conubii foedere copulatur --: 'ingressus sum in hortum meum, soror mea sponsa, uindemiaui murram meam cum unguentis meis, manducaui panem meum cum melle meo, bibi uinum meum cum lacte meo. edite, proximi mei, et bibite et inebriamini fratres mei. ego dormio, et cor meum uigilat.' cognoscamus quos fructus et cibos epuletur deus quibusue delectetur. delectatur eo, si quis mortificet peccatum suum, obliteret culpam suam, sepeliat atque abolefaciat iniquitates suas. murra enim sepultura est mortuorum, mortua autem peccata sunt, quae uitae suauitatem habere non possunt. perfunduntur autem diuini sermonis unguentis et fortiore cibo uerbi uelut pane et suauiore sermone uelut melle curantur quaedam uulnera delictorum. sermonum autem cibos esse docet et alibi Solomon dicens: 'faui mellis sermones boni.' in illo ergo horto sermones boni sunt, alius qui culpam coherceat, alius qui iniquitatem corripiat, alius qui mori faciat insolentiam et uelut sepeliat eam, quando correptus aliqui erroribus suis renuntiat. est etiam fortior sermo, qui confirmat cor hominis ualidioribus scripturae caelestis alimentis. est etiam sermo suasorius, dulcis ut mel et tamen peccatoris conscientiam in ipsa suauitate conpungens. est etiam feruentioris spiritus sermo, qui inebriat sicut uinum et cor hominis laetificat, est etiam lacteus sermo, purus et candidus. hos cibos dulcium utiliumque sermonum epulandos sponsus proximis suis dicit; proximi autem sunt qui eum sequuntur et nuptiis eius intersunt. quo cibo et potu repleta anima . . atque inebriata saeculo dormiebat, uigilabat deo, et ideo, sicut posteriora docent, aperiri sibi deus uerbum eius ianuam postulabat, ut eam suo repleret ingressu. hinc ergo epulatores illi Platonici, hinc nectar illud ex uino et melle prophetico, hinc somnus ille translatus est, hinc uita illa perpetua, quam deos suos dixit epulari, quia christus est uita. ideoque talium sermonum seminibus animae eius repletus est uenter atque ipsa exiuit in uerbo." 
Wherefore the bridegroom -- but the bridegroom of the soul is God the Word, to whom the soul is joined by what one might call a lawful bond of marriage -- says, "I have come into my garden, my sister, my bride. I have gathered my myrrh with my ointments; I have eaten my bread with my honey; I have drunk my wine with my milk. Eat, my friends; drink and become drunk, my brothers. I sleep and my heart is awake."

Let us understand what fruits and foods God feasts on and in which ones he delights. He delights in this: if one dies to one's own sin, erases one's fault, destroys and annihilates one's iniquities. For myrrh represents the burial of dead things, but what is dead are sins, which cannot possess the sweetness of life. And now certain wounds of sinners are drenched in the ointments of divine discourse, and are healed by the stronger food of the Word, as by bread, and by a sweeter discourse, as by honey. And elsewhere Solomon teaches that words are food, saying "Good words are a honeycomb."

Thus, in that garden there are good words: one which restrains fault, another which accuses of iniquity, another which causes the death of arrogance and buries it, as it were, whenever any who have been reproved renounce their errors. There is also a more powerful discourse which strengthens the human heart with the stronger food of heavenly scripture. And there is persuasive discourse which is sweet as honey yet, in its very sweetness, pricks the sinner's conscience. There is also the discourse of a more ardent spirit, which intoxicates like wine and gladdens the human heart; and there is discourse that is like milk, pure and white.

The bridegroom tells his friends that these foods of sweet and useful words are to be feasted upon; but his friends are those who follow him and take part in his wedding. By that food and drink the soul was filled... and, being drunk, was asleep to the world, but stayed awake for God. And thus, as later passages teach, God the Word asked that the soul's door be opened for him, so that he might fill it to overflowing by his entering.

Therefore, from this source have come those banqueters of Plato, from here that nectar has been translated from the prophet's wine and honey, from here that sleep, from here that endless life which Plato said his gods feast on, because christ is life. So the stomach of one's soul has been filled 
up by the seeds of such words and the soul itself has gone forth in the Word.

Being chastised, healed, strengthened, and otherwise fed by the words of God enables one to be filled by God the Word. ${ }^{18}$

The contact of soul and verbum in such a marriage, continuing Ambrose's favored imagery from the Song of Solomon, grants knowledge to the mind and virtual merger of the soul with the Word, as Ambrose describes in a discussion of another verse from that book (S. of S. 1.2: "Let him kiss me with the kisses of his mouth") in his treatise on Isaac: ${ }^{19}$

For this is the kiss of the Word, namely the light of holy knowledge. Indeed God the Word kisses us when he enlightens our heart and the human mind itself with the spirit of divine knowledge. . . . Through this kiss the soul clings to God the word; through it the spirit of the kisser is poured into the soul...

Thus, to paraphrase what Ambrose says in his commentary on Luke (Exp. evang. sec. Luc. 1.4 [n.14]), our faith -- our adherence to the Word -- is grounded both in the word

18 Elsewhere, in a somewhat similar image, Ambrose describes scripture as a "banquet of wisdom" and the holy books as different courses in the feast (De off. min. 1.165 [PL 16, 71B]: "Scriptura divina convivium sapientiae est: singuli libri singula sunt fercula").

19 De Isaac 8 (CSEL 32.1, 648.1-3, 7-8): "hoc est enim osculum uerbi, lumen scilicet cognitionis sacrae; osculatur enim nos deus uerbum, quando cor nostrum et ipsum principale hominis spiritu diuinae cognitionis inluminat. . . . per hoc osculum adhaeret anima deo uerbo, per quod sibi spiritus transfunditur osculantis. . ." 
himself and in the illuminated knowledge he makes available to our reason, verbo atque ratione.

God and God's word, in both its senses of scripture and of Christ, are the source and illumination of the knowledge -- and the wise actions -- proper to God's rational creatures. From God alone come the best human thoughts and the ability to contemplate holy things (De Cain 1.45). The wisdom who is Christ is the fount of all the virtues (De par. 13-4) and the teaching available in the gospels can lead us to justice (De Jacob 1.9). It is by divine gift that human beings are able to think appropriately and faithfully about God (Ep. 65.2); in fact, human rationality was granted precisely in order that we may seek that divinity which is not far from us but, rather, within which we exist (Ep. 43.10).

According to Ambrose, rhetoricians deride scripture for failing to follow their art in providing cause (aition), material (hyle), and completion (apotelesma) in its arguments, yet Ambrose notes that in the story of Abraham's near-sacrifice of Isaac all three are present: fire the cause, wood the matter, and the ram the completion of the sacrifice. So it is with mental activity: the fervent mind is, like fire, the actor; intelligible things are the matter on which the mind acts; and the third component, the completion, is understanding. Just as God provided the ram as the end of Abraham's act, 
so God gives the gift of understanding to human beings as the perfection of the mind's activity. Indeed, the Word of God -- the ram in whom the sacrifice is fulfilled -- is the true apotelesma, "the delimitation and completion of disputation". ${ }^{20}$ Especially to be noted here is Ambrose's close identification of the gift of understanding and the end of mental activity with christ.

Ambrose teaches that we shall attain a fuller knowledge of God once we are freed of this body, when we shall see Christ in his glory in the kingdom of God (De fide 5.152), but even in earthly life it is true that the one whom Jesus touches sees more (Ep. 80.4). The close interrelation among God's gifts of the word, the word, and

20 Ep. 8.2-5 (PL 16, 912B-913B): "Denique in arte requiruntur praecipue, ut sit aition, hyle, apotelesma; cum igitur legamus sanctum Isaac Patri dicere: 'Ecce ignis et ligna, ubi hostia?' . . . Ecce ignis, id est aition: et ligna, id est, hyle, quae Latine materia dicitur: tertium quid superest, nisi apotelesma, quod filius quaesivit, pater retulit dicenti. 'Ubi hostia? Deus,' inquit, 'providebit sibi sacrificium, fili.'

Differamus paulisper mysterium. Ostendit Deus arietem pendentem cornibus: aries autem est Verbum . . . quo ostenditur bonum sacrificium esse sapientiam, et prudenter emerendi ac propitiandi rationem cognoscere. . . Ecce ergo mens calida et fervens, ut ignis, quae operatur: ecce et intelligibilia, id est, materia; ubi est tertium, intelligere? . . . ideoque Deus dat munum intelligendi, et sentiendi, et videndi.

Verbum ergo Dei apotelesma est, id est, definitio et consummatio disputationis, quod infunditur prudentioribus, et dubia confirmat." 
human understanding is further displayed in Expositio psalmi CXVIII: ${ }^{21}$

But God teaches and illuminates the minds of individuals and pours in the clarity of knowledge, if you open the doors of your heart and welcome the clarity of heavenly grace. When you have doubts, seek diligently, because "the one who seeks will find, and to the one who knocks it shall be opened." There is much obscurity in the prophetic writings. But if with the hand of your mind, so to speak, you knock on the door of the scriptures and examine carefully those things which are hidden, gradually you will begin to gather the meaning of the sayings. It will be opened to you not by another but by the word of God, about whom you have read in Revelation that the lamb opened the sealed book, which no one could open before, because only the Lord Jesus revealed in his own gospel the riddles of the prophets and the mysteries of the law. Only he brought down the key of knowledge and gave it to us to open.

Similarly, it is Christ who "has inflamed your heart, so that you might understand the meaning of divine commands, the substance of the soul, and the grace of the life to come." 22 understanding is a gift from God,

21 Exp.ps. 1188.59 (CSEL 62, 188.15-26): "docet autem deus et mentes inluminat singulorum et claritatem cognitionis infundit, si tu aperias ostia cordis tui et caelestis gratiae recipias claritatem. quando dubitas, diligenter inquiras; 'qui' enim 'quaerit inuenit, et qui pulsat aperitur ei.' multa obscuritas in scripturis propheticis. sed si manu quadam mentis tuae scripturarum ianuam pulses et ea quae sunt occulta diligenter examines, paulatim incipies rationem colligere dictorum et aperietur tibi non ab alio, sed a dei uerbo, de quo legisti in Apocalypsi, quod agnus librum signatum aperuit, quem nullus ante aperire poterat, quia solus dominus Iesus in euangelio suo prophetarum aenigmata et legis mysteria reuelauit, solus scientiae clauem detulit et dedit aperire nobis."

22 Exp.ps. 1185.31 (CSEL 62, 99.18-20): "inflammauit [Christus] cor tuum, ut conprehendas quae mandatorum caelestium ratio, quae animae substantia, quae uitae futurae gratia . . ." 
without which it is not possible to know the Lord's secret things, and it is sought so that one might guard against sin -- once again the primary moral significance of knowledge (Exp.ps. 118 16.34-5; cf. 13.12, 17.27, and $18 \cdot 45-8)$

Thus, the true source of knowledge and understanding, and thereby of the possibility of a moral life, is God, as revealed in scripture and available to the human heart in Christ. To turn away from the fountain of wisdom is to settle for merely human wisdom, the wisdom of the world that offers nothing but vacuous philosophical debates and the illusory pleasures of the flesh, and cannot save us. To be anchored in scripture and focused on Christ, on the other hand, is to be on the way to the true wisdom that abides in and emanates from the bosom of God.

\section{The authority of scripture}

In his expository sermons about the six days of creation, as Ambrose moves from the first day to the second, he asks his audience to consider his words with a simple and attentive mind, ${ }^{23}$

23 Exam. 2.3 (CSEL 32.1, 42.12-8): "uos igitur quaeso ut naturaliter aestimare quae dicimus probabiliter ac simplici mente et sedulo ingenio pensare dignemini, non secundum philosophiae traditiones et inanem seductionem suasoriae ueri similia colligentes, sed secundum regulam ueritatis, quae oraculis diuini sermonis exprimitur et contemplatione tantae maiestatis fidelium pectoribus infunditur..." 
not according to the traditions of philosophy and to those who gather likenesses of truth in the empty deception of the persuasive art, but according to the rule of truth which is expressed in the prophecies of the divine word and poured into the breasts of the faithful in the contemplation of such sovereignty . .

The maiestas of scripture and the truth it expresses is such that, even when an argument has been made clearly and forcefully in reason's terms, it is still important to seal it with a clinching scriptural proof. ${ }^{24}$

Scripture affords not only the authoritative rule of truth but the additional information that some knowledge is not possible for human beings (Exam. 6.7). There are even parts of scripture itself which are not accessible by the human intellect and, therefore, are not appropriately judged from a merely human point of view (De par. 7). Scripture's authority is based on its ability to lead human beings to wisdom, to teach the truth about human life and divine love. In the allegory of the rivers of paradise, Phison, the river that signifies prudentia, is the location of gold and precious stones. It is said that thoughtful arguments are like gold, but it is in the scriptures that pure and incorruptible gold is to be found, for "one who has clung closely to the old and the New Testament can go forward, in the fruitfulness of

24

De bon. mort. 43 (CSEL 32.1, 739.22-3): "Habemus ergo rationem [from Plato]. sed haec humana, illud diuinum, quod ait dominus [followed by citation from John's gospel]." See also De off. min. 1.36, 151; Exp. evang. sec. Luc. 8.67; De fide 3.24. 
debate, into the actual secret places of the wisdom of God." 25

De paradiso was written in the first years of Ambrose's episcopacy; in a letter written toward the end of his ministry -- in 396, the year before his death -Ambrose repeats his enduring conviction of the difficulties of interpretation, the power of scripture to illuminate, and the centrality of the Word, once again couched in a river metaphor: ${ }^{26}$

The old scripture is deep and more shadowy, like a well from which you may drink only with effort; and it does not satisfy because the one who fulfills it has not yet come. . . For one who drinks from the New Testament, it is not a single river but rather rivers of living water flowing out of his belly: rivers of understanding, rivers of thought, rivers of spiritual things...

Just as food is ripened by the sun's warmth and acquires greater nourishing qualities when it has been

De par. 15 (CSEL 32.1, 274.9-11): "eo quod ueteri et nouo qui inhaeserit testamento in ipsa secreta sapientiae dei disputationis possit ubertate procedere."

This is one of several instances in which Ambrose uses disputatio in a positive sense, suggesting that his argument is not with the notion of dialectical debate itself but with the manifest pointlessness of non-christian philosophical dialectics.

26 Ep. 63.78 (PL 16, 1210B-C): "vetus Scriptura quasi puteus profunda atque obscurior, unde cum labore haurias: non plena; quia adhuc qui impleret eam, non venerat. . . . qui de novo Testamento biberit, non solum flumen est, sed etiam flumina de ventre ejus fluent aquae vivae, flumina intellectus, flumina cogitationis, flumina spiritalia. . ." 
heated in a fire, so the power of the soul is engendered and enhanced when kindled by God's word: ${ }^{27}$

Most of the discourse of the scriptures strengthens the soul and "browns" it by the warmth, so to speak, of spiritual grace; it also fortifies rational arguments and weakens all the force of the irrational passions.

There is power in talk of holy things, a power that is missing from public philosophical discourse, which can reflect only the vanity of the world (Exp.ps. 118 11.12). Thus, Job was able to survive his terrible afflictions precisely because he had found his strength in scripture; "he was molded by the moral lives of the patriarchs and directed by instruction in heavenly prophecies and natural law." 28

As Ambrose declares later in the commentary on Psalm 119, "the gospel is not only an education in faith, but a teacher of morals and a mirror of the just way of

27 De Cain 2.20 (CSEL 32.1, 395.20-3): "sermo igitur plurimus scripturarum animam confirmat et quodam spiritalis gratiae colorat uapore, rationabilia quoque inuenta conroborat dissoluitque omnem uim inrationabilium passionum." (The cooking metaphor used in the translation reflects the fact that the preceding part of the paragraph is a series of images based on heat's ripening and cooking effects, including burnt offerings and roasted ears of corn.)

28 Exp. ps. 11812.29 (CSEL 62, 268.21-4): "Quanta simul coaceruata sunt, ut illa adflictione Iob sanctus periret! sed quia patriarcharum moribus informatus oraculorumque caelestium et naturalis legis erat institutione formatus, ideo in temptationibus tantis perire non potuit." 
life."29 However, scripture is also a fidei doctrina for Ambrose and that role is not less important than its instruction about the moral life. The divine words are authoritative not only because they are efficacious for living a good and, ultimately, blessed life but also, and essentially, because they are true and worthy of belief. As Ambrose teaches, in regard to Psalm 119.160 ("The beginning of your words is truth"), 30

since the origin of God's words is truth, truth is at least the foundation of faith. For it is right, first, that we believe the prophecies of the highest God, which we read in holy scripture, to be true, and second, that we learn their excellence by fuller knowledge.

\section{The primacy of faith}

For all the understanding and strengthening of reason that scripture affords, faith remains the primary essential characteristic of one who would attain the wisdom and presence of God. Ambrose even goes so far as to say that, in the question of the resurrection of the body, if he is convinced by reason, he has thereby denied

29

Exp. ps. 11820.33 (CSEL 62, 460.29-461.2): "euangel ium etenim non solum fidei doctrina, sed etiam morum est magisterium et speculum iustae conuersationis."

30

Exp. ps. 11820.56 (CSEL 62, 472.17-23): "Sequitur ultimus uersus litterae huius: 'principium uerborum tuorum ueritas, in aeternum omnia iudicia iustitiae tuae.' cum principium uerborum dei ueritas sit, ueritas utique fidei fundamentum est. primum etenim oportet ut credamus uera esse dei summi quae in diuinis scripturis legimus oracula, secundum est, ut uirtutem eorum pleniore cognitione discamus." 
faith (De exc. fratr. 2.89). In his anti-Arian treatise De fide he exclaims, "Away with arguments where faith is required," and asks how anyone could possibly follow Jesus on the basis of mere conjecture rather than faith. ${ }^{31}$

In the commentary on Luke, when the topic is the same as that in De fide 1.84 - the thorny question of how the generation of the son is to be understood in trinitarian theology -- Ambrose again relies on faith rather than reason: "Although the human mind cannot grasp it by reason's thorough exploration, yet it is comprehended by the fullness of faith." ${ }^{32}$ Likewise, Abraham's unquestioning response to God's command teaches that it is "a good thing that faith come before reason," lest we find ourselves in the untenable position of demanding a rational argument from God as we would from another person. ${ }^{33}$

Faith's primacy over reason is another way of emphasizing the limitations of human reason and the

31 De fide 1.84 ( CSEL 78, 36.43-37.44): "Aufer hinc argumenta, ubi fides quaeritur."

De fide 4.3 (CSEL 78, 159.9-10): "Quis enim potuit opinione magis quam fide sequi dominum Iesum . . ."

32 Exp. evang. sec. Luc. 4.71 (CC 14, 132.883-4): "Quam licet mens non queat humana plenae rationis inuestigatione conprehendere, fidei tamen plenitudo conplectitur."

33 De Abr. 1.21 (CSEL 32.1, 517.1-4): "bonum est ut rationem praeveniat fides, ne tamquam ab homine ita a domino deo nostro rationem uideamur exigere. etenim quam indignum ut humanis testimoniis de alio credamus, dei oraculis de se non credamus!" 
importance of humility in the face of those limits.

Abraham moved from the land of the Chaldees, signifying vain philosophical meanderings (as Egypt is the denotation of Moses' early sojourn in the halls of worldly wisdom), to Canaan, which represents true worship, characterized by humility. only in Canaan, having taken on humility, did Abraham begin to see God as God, as the governing power of the universe. 34

Obedience and knowledge, faith and the moral life, are inseparably intertwined in Ambrose's thought and their interrelations color most of what he says about scripture and human participation in divine wisdom. Psalm 119.66 ("Teach me delight and discipline and knowledge because I have believed in your commands" ${ }^{35}$ ) evokes from him these comments : ${ }^{36}$

34 De Abr. 2.9 (CSEL 32.1, 570.21-4, 571.17-21): "unde 1 iquet eo referendum quia, quamdiu chaldaeus fuit, hoc est non solum in regione, sed etiam in opinione chaldaeorum, non poterat deum uidere, quem intra mundum quaerebat. . . . ubi uero ad aliam demigrauit non regionem, sed ueram religionem paratam humilitati -- hoc enim significat Chanaan --, tunc deum uidere coepit et eum cognoscere esse deum, cuius inuisibili uirtute aduertit omni regi et gubernari."

35 This is a translation of Ambrose's version of verse 66: "iucunditatem et disciplinam et scientiam doce me, quia in mandatis tuis credidi" (Exp. ps. 118 9.9, CSEL 62, 194.20-1). In the NRSV, the verse reads, "Teach me good judgment and knowledge, for I believe in your commandments."

36 Exp. ps. 118 9.11-2 (CSEL 62, 195.21-196.7, 9-10): "Sed qui petit doceri bonitatem et disciplinam, debet petere etiam scientiam doceri. nisi enim habeat scientiam, molesta est disciplina, molesta correptio. quid sit scientia, doceat te salomon, qui ait de domino deo nostro: 'ipse enim mihi dedit eorum quae sunt cognitionem ueram.' et alibi hic 
One who desires to be taught goodness and discipline must also ask to be taught knowledge. For unless one possesses knowledge, discipline is tiresome, correction is tiresome. Learn from Solomon what knowledge might be, who says of our Lord God, "God gave me true knowledge of the things which exist." And elsewhere the prophet speaks of God: "the one who teaches human beings knowledge." But one who desires knowledge has faith in the commands of God.

However, it is one thing to believe in the commands of God, another to have faith in the commands. For those who have faith in God's commands accomplish them quickly so they may be in God's commands and live their lives within them. Therefore, through faith knowledge is obtained, through knowledge discipline; for the way of life itself, within that which we know is able to please, delights us. Thus, it is written, "our way of life is in heaven." Knowledge preceded; the way of life followed. . . Unless you have faith in the commands of God, at any rate you will not be able to possess knowledge of the things we are taught by means of God's commands.

Moral practice (accomplishing God's commands), and the consequent delightful way of life, require knowledge and knowledge is acquired through faith. But, when Ambrose explicates the second half of Psalm 119.73 ("Give me understanding so that I may learn your commands"), it is understanding which is given first so that knowledge

idem propheta ait: 'qui docet hominem scientiam.' qui autem petit scientiam, credit mandatis dei.

Aliud est autem in mandatis dei credere, aliud mandatis credere. qui enim mandatis dei credit, cito efficit ut sit in mandatis dei et in ipsis conuersetur. per fidem igitur scientia adsumitur, per scientiam disciplina; quod enim scimus placere posse, in eo nos conuersatio ipsa delectat. denique scriptum est: 'nostra autem conuersatio in caelis est.' praecessit scientia, secuta est conuersatio. . . nisi autem credideris mandatis dei, eorum utique scientiam quae per mandata dei docemur habere non poteris." 
may follow. ${ }^{37}$ However, these two formulas (faith must precede knowledge; understanding must precede knowledge) are not contradictory, given Ambrose's conviction that understanding -- particularly understanding of God's word -- is given by God through christ and is received by faith in Christ.

The commentary on Psalm 119 includes several such interlocking formulas, and similar examples can be found in Ambrose's other writings as well. Ambrose teaches that we must seek wisdom so that we may then walk in the just way (De interpel1. 2.23); on the other hand, we must first learn to walk in the way and correct our behavior before we can bring perception to our studies or meditate on God's law (Exp.ps. 1181.2 , which refers not only to Ps. 119.1, but also to the order of phrases in Ps. 1.1-2). We cannot keep the law -- and stay in the correct way -without understanding and we must, therefore, seek that understanding from God in Christ, although without the law we cannot attain Christ (Exp.ps. 118 5.22-25; cf. 13.26$7,15.2-3,16.34)$.

The apparent circularity of Ambrose's thought is evidence of neither carelessness nor confusion on his part; for Ambrose the distinctions among keeping God's

37 Exp.ps. 118 10.19 (CSEL 62, 215.8-13): "deinde uide ordinem: 'da mihi,' inquit, 'intellectum, ut discam mandata tua.' intellectus praemittitur, ut scientia sequatur; nam nisi quis intellexerit, doctus esse non poterit." 
commands, understanding God's word, and receiving Christ are little more than semantic variations, useful for changing emphases in his preaching but not to be mistaken for truly different parts of the Christian life. Just as the Father, Son, and Spirit are one in the Trinity, so moral conduct, understanding scripture, and christian faith are all interdependent aspects of the christian way of life, and that way of life comprises virtually all that Ambrose wishes to say about the content of christian wisdom. ${ }^{38}$

\section{Wisdom as the way}

The commentary on Psalm 119, the richest source of Ambrose's thoughts on Christian wisdom, is also an essay on "the way." 39 A journey through the commentary, noting

38 In Ambrose's time, philosophy was generally understood to be a way of life to be practiced rather than a body of speculative knowledge to be studied. Recognition of Christianity as likewise a way of life seems to have begun in the second century of the Common Era, as evidenced by Galen's references to Christianity as a philosophical school (Wilken 1984, 77-82). See also chapter one, page 26 and notes 29 and 31 .

39 Meeks $(1993,70)$ describes the metaphor of two possible paths of life -- the choice between a life of vice or of virtue marking a figurative fork in the road -- as a commonplace in the early centuries of the Common Era. The locus classicus for the metaphor is the tale of Heracles's choice, attributed to Prodicus and recorded by Xenophon (Memorabilia 2.1.21-34). The same parable is used by Ambrose in De Cain et Abel, following Philo, and serves there to contrast human and divine wisdom (see chapter three, pp.92-3 and n.10). 
Ambrose's many varied references to the via, reveals the nature and importance of the way of Christian wisdom.

The first verse of the psalm invokes a blessing on those blameless ones who are in via, who walk in the law of the Lord. Ambrose's discussion of this pervading theme then begins with a declaration that his book is to be about life and how it is to be lived, not about abstract doctrina, and with a summary statement about the primary importance of moral reform and the secondary (though still important) status of knowledge: ${ }^{40}$

It says, 'Blessed are the unstained ones in the way, who walk in the law of the Lord. Blessed are those who search his testimonies, who seek him with their whole heart.' How excellent the order, how full of teaching and grace! It does not first say 'those who search his testimonies' -- certainly that would be appropriate according to the letter ['Aleph,' designation of the first verse octad, is said to signify 'doctrina'] -- but first it says: 'blessed are the unstained ones in the way.'

40 Exp. ps. 1181.2 (CSEL 62, 5.9-27): "'Beati inmaculati,' inquit, 'in uia, qui ambulant in lege domini. beati qui scrutantur testimonia eius, in toto corde exquirunt eum.' quam pulcher ordo, quam plenus doctrinae et gratiae! non prius: 'qui scrutantur testimonia eius' dixit -- potuit enim conuenire secundum litteram --, sed prius: 'beati inmaculati in uia.' ante enim uita quam doctrina quaerenda est. uita enim bona et sine doctrina habet gratiam, doctrina sine uita integritatem non habet; 'in maliuolam' etenim 'animam non cadet sapientia.' ideoque ait: 'quaerent me mali et non inuenient,' quia inprobitate caecatur mentis oculus et caligante sibi iniquitate mysteria profunda inuenire non potest. primum ergo exercenda est uitae militia, corrigendi mores. cum haec instituerimus ad cursum debitum, ut sit offensionis correctio, puritatis gratia, tunc ad studia percipiendae cognitionis ueniamus suo ordine et uia. prima igitur sunt moralia, secunda mystica. in illis uita, in his cognitio, ita ut, si perfectionem requiras, nec uita sine cognitione nec cognitio sine uita sit, utrumque adstipuletur alteri." 
Indeed life is to be sought before learning. For a good life, even without learning, has grace; learning without life does not have integrity: 'wisdom will not descend into a malevolent soul.' Therefore, it is written, 'evil ones will seek me and not find me,' because the eye of the mind is blinded by wickedness and, darkened by sin, cannot discover the deep mysteries. First, therefore, we must carry out the military campaign of life, of improving behavior. When we have undertaken this obligation for the course to be run, so that there may be amendment of error and the grace of purity, then we may come to pursuits for the attaining of knowledge by their own order and way. Therefore, first moral issues, then mystical. In the former is life, in the latter knowledge, in order that, if you seek perfection, there may be neither life without knowledge nor knowledge without life; let each support the other.

To be morally good is to walk in the way, but not in just any way; it is to walk in Christ, who is the way: ${ }^{41}$

But who is the unstained one? Not, at any rate, the one who walks in any way, but the one who walks in christ. For he himself has said, "I am the way." Those who walk in this way do not know how to err, if only they never depart from this way. The way is law and, therefore, while they are unstained, they walk in the law of the Lord; nor should they cease to walk in this way, lest they cease to be unstained.

References to John 14.6, in which Jesus says, "I am the way, the truth, and the life," appear throughout the commentary, reminding the reader that Ambrose is constantly aware that for him to speak of wisdom and the way is to speak of Christ, who is both Wisdom and Way.

41 Exp.ps. 1181.8 (CSEL 62, 9.21-6): "Sed quis est inmaculatus? non utique qui in quacumque uia ambulat, sed qui in Christo ambulat. ipse enim dixit: 'ego sum uia.' in hac uia qui ambulat, errare non nouit, si tamen ab hac uia numquam recedat. est et uia lex, et ideo, dum inmaculatus est, in lege domini ambulat; nec ambulare in uia hac desinat, ne inmaculatus esse desistat." 
"Indeed, the way of those who seek God is Christ. . . For he himself is salvation, truth, virtue, and wisdom. 142

In one of the exegetical excursions into the song of Solomon that are so characteristic of his discussion of Psalm 119, Ambrose begins with the first part of verse 133 of the psalm ("Direct my steps according to your word") and quickly turns to song of Solomon 7.1 where the bride, or the human soul, is told how beautiful her steps appear in sandals. Then, by way of the command to Moses to take off his sandals before the burning bush (Ex. 3.5), Ambrose explores the spiritual meaning of verse 133, connecting the mystical sandals -- and other garments -- of the soul with the call to follow the way of wisdom: ${ }^{43}$

The good sandal of the soul is modesty; the good step is in the footprint of chastity. But wisdom is the cloak of the soul, as it is written, "honor her [wisdom] and she will enfold you." Therefore, let us use the body as a sandal for the works of lesser virtue, for service and not for command, for compliance and not for delight, for obedience and not for conflict; and let us place our footprint in

42 Exp. ps. 11811.6 (CSEL 62, 236.9, 19-20): "Etenim requirentium deum uia Christus est. . . . ipse est enim salus, ueritas, uirtus atque sapientia."

43 Exp. ps. 11817.16 (CSEL 62, 386.3-10): "bonum calciamentum animae pudicitia est, bonus gressus est in uestigio castitatis. sapientia autem amictus est animae, unde scriptum est: 'honora eam, et amplectetur te.' utamur igitur corpore tamquam calciamento ad inferioris opera uirtutis, ad ministerium, non ad praeceptum, ad obsequium, non ad delectationem, ad oboedientiam, non ad dissensionem et in uia sapientiae uestigium conlocemus, ne gressus nostros uis torrentis aliqua concludat." 
the way of wisdom, lest somehow the power of a rushing stream restrict our steps.

According to Ambrose, one who studies scripture carefully is better able to walk in the way, because God's witness, like the testimony of conscience, makes the truth of sin inescapable. ${ }^{44}$ The awareness of sin is vital, for to deviate even a little from the way is not to be in the way at all; it is, therefore, necessary to seek God's guidance for the mind's footsteps so that one may stay in the path by keeping God's commands: ${ }^{45}$

44 Exp. ps. $1181.9-10$ (CSEL 62, 10.8-10, 11.12-5, 225): "si quis ergo in uia ambulat, scrutetur testimonia domini. quod licet mysterium sit, tamen etiam moralia in se habet, quoniam melius potest ambulare in uia, qui scrutatur domini testimonia. . . . sed non uis credere, ne possis cauere; non uis audire, cum legitur, quia deus nouit occulta hominum, ne incipias scire quod timeas a uia praua et maligna. . . ipsum te fugere tui accusatorem non potes, quem conuenit propria conscientia, et si negas aliis, tibi non negas, et si homini infitiaris, deo fateris, et si uolueris negare, tuae te cogitationes reuincunt."

45 Exp.ps. $1181.14-5$ (CSEL $62,14.15-6,19-15.8,12-$ 4): "'tu mandasti mandata tua custodire nimis.' . . . non solum: 'mandasti,' inquit, 'custodire mandata tua,' sed etiam: 'custodire nimis.' quando hoc mandauit? in paradiso quidem mandauit Adae, ut custodiret mandata; sed fortasse non mandauerat nimis custodire et ideo lapsus est, ideo inflexus uoce mulieris suae, ideo deceptus erat a serpente putans quod, si in parte aliqua recederet a mandato, non penitus erraret. sed quia semel a semita mandatorum recessit, totam deseruit uiam, inuenit eum serpens extra uiam et expoliauit omnibus, nudum reliquit. ideo dominus, quia lapsus erat qui in paradiso erat, postea per legem per prophetas per euangelium per apostolos monuit, ut nimium custodias mandata domini dei tui. omne, inquit, uerbum quod locutus fueris, reddes pro eo rationem. noli dissimulare; ab aliquo mandato iota unum uel unus apex non praeterit. noli recedere de uia. si in uia ambulans uix tutus es a latrone, quid facies, si te extra uiam uagantem inuenerit? dirigantur gressus tui et, ne infirmus sis ad dirigendum, precare, ut dominus dirigat uias tuas. 
"You have ordered [me] to keep your commands to the utmost" [Ps. 119.4]. . . . Not only does it say, 'you have ordered [me] to keep your commands,' but rather 'to keep them to the utmost.' When was this ordered? In paradise, in fact, it was ordered of Adam that he keep the commands; but perhaps he was not ordered to keep them to the utmost and, therefore, he fell -- therefore, he bent to the voice of his wife; therefore, he was beguiled by the serpent -- thinking that, if he were to depart from the command in some respect, he would not err completely. But, because once he departed from the path of the commands he abandoned the whole way, the serpent found him outside the way and stripped him of everything, left him naked. Thus, because he who was in paradise had fallen, the Lord thereafter gave warnings -- through the law, the prophets, the gospel, the apostles -- so that you might keep to the utmost the commands of the Lord your God. It is written that you will give an account before him for every word you have spoken. Do not feign ignorance; not one iota, not one point of any command will escape notice. Do not depart from the way. If you are scarcely safe from a highwayman when you are walking in the way, what would you do if the robber were to find you wandering outside the way? Let your steps be guided and, lest you be weak in guiding, pray that the Lord may guide your ways. - . Therefore, ask that the Lord may guide the footsteps of your mind, by which you can keep the judgments of the Lord.

In his exegesis of Psalm 119.9 ("How does a young man straighten out his way? By keeping your words"), Ambrose asserts that anyone who sincerely seeks to correct his or her way need not be perplexed but can obtain God's counsel through prayer. A mind so directed, "sprinkled with the

mentis tuae, roga ergo et tu, ut dominus dirigat uestigia 
seeds of heavenly words," begins to bear better fruit, manifested in the ability to walk a straight path. 46

Later in the commentary, Ambrose returns to the topic of correcting one's way when he discusses verse 59: "I have considered my ways and turned my feet to your testimonies." 47 Ambrose teaches that this pondering of one's ways has two meanings. In one sense, it refers to the need to reflect upon one's past behavior in order to recognize one's sins and then to merit remission of those sins -- and the possibility of prevention of future sins - "by a change in behavior and a devotion to virtue," the outward manifestation of turning one's feet to God's testimonies. ${ }^{48}$

46 Exp.ps. 1182.2 (CSEL 62, 20.4-11): "Et respondet: 'in custodiendo uerba tua.' et bene ad deum conuersus respondit deliberanti, quasi prece atque oratione delata consilium hoc domini inspiratione reppererit, ut non praesumptionis humanae, sed dignationis diuinae remedium crederetur. mens enim nostra uerborum caelestium conspersa seminibus, quae ante degenerabat in stirpibus, meliores cultus edere fructusque adferre incipit. dirigamus igitur semitas nostras nec tortuosi serpentis sequamur anfractus."

47 This is Ambrose's version: "Cogitaui uias meas et auerti pedes meos in testimonia tua" (Exp. ps. 118 8.31, CSEL 62, 168.7-8). In contrast, the NRSV translation of verse 59 reads: "When I think of your ways, I turn my feet to your decrees." In both Vulgate versions, LXX and Hebrew, it is "my ways" that are to be considered, not "your ways."

48 Exp.ps. 1188.31 (CSEL 62, 168.8-14): "diuiduus sensus: aut quia uias superiores meas cogitaui plenas lapsus atque peccati, et ideo, ut remissionem peccatorum possim mereri morum conuersione studioque uirtutum, auerti pedes meos in testimonia tua, ut non iam meis gressibus, quibus ante sum lapsus, sed testimoniorum tuorum itineribus ambularem, quo tuorum semitae mandatorum me errare non sinerent nec uestigium in deuia et tortuosa deflecterem." 
In the other sense, the ways to be considered are future paths of action; it is necessary to think before one acts so that what is to be done will be fitting and will not be an eventual occasion for repentance. If we are accustomed to thinking beforehand which route is the correct one to take to reach an earthly city, how much more important it is to think carefully about which way our souls and minds should follow if we are to attain the heavenly Jerusalem, the Kingdom of God. ${ }^{49}$ Moreover, whether it is a matter of past ways or future ways, as Ambrose says elsewhere in the commentary (referring to Ps. 119.168), "blessed is one who can say, 'all my ways are before you,' one who does not wish to hide all his or her thoughts and actions. " 50

49 Exp. Ps. 1188.32 (CSEL 62, 168.21-6, 169.5-6, 13-7): "Hic ergo sensus unus est, alius autem ita: 'cogitaui uias meas,' non superiores, sed futuras, ut ante meos actus cogitationibus praeuenirem, ne inconsulta operatione progressus aliquid in ipsis conationibus offensionis inciderem, ut si agere aliquid uelim, ante cogitem, utrum agendum sit illud quod desidero aut quo agendum modo . . . omnia igitur cum cogitatione facito, ut non te paeniteat operis tui. . . . stas igitur cogitans quae sit uia, quae in ciuitatem ducat ad quam tibi putas esse pergendum, quanto igitur magis animo debes ac mente consistere, qui ad regnum caeleste contendis, et cogitare tecum, quia non omnis uia illo ducit, non omnis uia illo dirigit ad Hierusalem illam quae in caelo est!"

The discussion of the importance of thinking first in order not to go astray from the correct via continues through Exp. ps. 118 8.33-5.

50 Exp. ps. $11821.24(\underline{\operatorname{CSEL}} 62,487.18-20)$ : "beatus qui potest dicere: 'omnes uiae meae ante te,' qui nolit abscondere omnes cogitationes suas, omnes actus suos." 
Invoking a polarity that recalls his "doctrinal dualism," the contrast of Christian wisdom with the wisdom of the world in all its guises, Ambrose says that it is necessary to know the difference between God's way and our own ways, which are the ways of the flesh and of worldly wisdom that must be abandoned: ${ }^{51}$

The soul that walks the ways of christ is made alive -- dead to sin, alive to God -- so that then the death of sin cannot have dominion in it; after it has been buried with christ, it is justified from sin. But let one who wishes to be justified first proclaim his or her own ways. Therefore, the second verse [Ps. 119.26] says, "I proclaimed my ways and you heard me; teach me your precepts." $\mathrm{He}$ [the psalmist] discusses arriving at the precepts of God in excellent order

51 Exp.ps. 118 4.9-10 (CSEL 62, 72.4-29): "uiuificatur autem anima, quae uias ambulat christi, peccato mortua deo uiuens, ita ut mors peccati dominatum in ea posthaec habere non possit, posteaquam consepulta cum christo iustificata est a peccato. sed qui iustificari cupit, uias suas ante pronuntiet.

Ideoque secundo uerso ait: 'uias meas pronuntiaui, et exaudisti me; doce me iustificationes tuas.' pulchro ordine ad iustificationes dei perueniendum putat, ut primum sua peccata fateatur. sic enim docemur et alibi: 'dic iniquitates tuas, ut iustificeris.' itaque scire debemus, quid sit uias suas ambulare hominem et uias dei. qui facit uoluntates carnis et uiuit secundum concupiscentiam mundi huius, uias suas ambulat, quibus delectatur et gaudet; qui autem uenit uoluntatem facere patris sui qui in caelis est, cuius cibus est ut mandatum dei conpleat, qui non quaerit quod sibi uoluptati sit, sed quod placeat deo, ille uiam domini pergit, illam uiam, quae ait: 'ego sum uia et ueritas et uita.' uides ergo, quia ille uiuit secundum uerbum dei, qui uiam ambulat Christi. ipse etiam dominus deus in Deuteronomio docet, quomodo in uiis suis ambules, dicens: 'et nunc, Israel, quid dominus deus petit a te, nisi ut timeas dominum deum tuum et ambules in uiis eius et diligas eum et seruias domino deo tuo ex toto corde tuo et ex tota anima tua, custodias mandata eius et iustitias eius?' liquet igitur alias uias esse carnis, alias dei, et si quis uelit ambulare uias dei, ei prius esse uias carnis et corporis et saecularis sapientiae deserendas." 
in that first he acknowledges his own sins. For thus we are also taught elsewhere: "Tell your sins so you may be justified." Therefore, we ought to know what it is for people to walk their own ways and to walk the ways of God. Those who do the will of the flesh and live according to the lust of this world walk in their own ways, in which they delight and rejoice. But the one who comes to do the will of his father who is in heaven, whose food it is to fulfill the command of God, who seeks not what is desirable for himself but what is pleasing to God, he continues on the way of the Lord, that way which says, "I am the way and the truth and the life." You see then that the one who walks the way of Christ lives according to the word of God.

Even so the Lord God teaches in Deuteronomy how you may walk in his ways, saying, "And now, Israel, what does the Lord God ask of you except that you fear the Lord your God and walk in his ways and love him and serve the Lord your God with all your heart and all your soul, and that you keep his commands and his precepts?" It is clear then that some ways are of the flesh, some ways are God's, and, if one wishes to walk the ways of God, first the ways of the flesh and of the body and of worldly wisdom must be given up for him.

Psalm 119.29 asks that the way of $\sin$ be taken from me -- rather than that I be taken out of the way of sin -to show that sinful ways are deep within us as long as we persist in doing wrong. ${ }^{52}$ The removal of the deviant path from us requires our devotion and faith, our

52 Exp.ps. 1184.22 (CSEL 62, 78.4-9): "Confirmatus igitur in uerbis ait: 'uiam iniquitatis amoue a me et lege tua miserere mei.' non dixit: 'amoue me a uia iniquitatis,' sed: 'uiam iniquitatis amoue a me,' quasi in nobis sit et nobis inesse uideatur. quamdiu enim exercemus aliquid inprobum, uia iniquitatis interius manet et non recedit a nobis; ideoque studiose agamus, ut eam a nobis separemus." 
committed choice of the true way, in rejection of all the many paths that comprise the contrasting false way: ${ }^{53}$

But the prophet, who wished with genuine emotion to be changed, said, "I have chosen the way of truth; I have not forgotten your judgments" [Ps. 119.30]. One who errs in doctrine cannot say this; an Arian cannot say it; a Sabellian cannot, nor a Manichean. The avaricious one who lusts after worldly and material things cannot say it; one who does business cannot say it. For the way of truth is not a devotion to having, a desire for possessing. How could that be the way of truth, when that man who was rich in the world was not able to bring his riches with him and after death began to be needier than that beggar Lazarus? The way of truth is not the respect of this age or anxious attention to the world. Finally, the one who has chosen the way of truth says a little later: "Turn my eyes away so that they may not see vanities" [Ps. 119.37]. Vanity is a matter of temporal things, truth of eternal things. So if we wish to walk in the way of truth, let us be a stranger to the world rather than to God and let us walk through faith. For the one who walks through faith is in the presence of God; one who walks through appearances is present to the world and a stranger to the Lord, but here is quickly confounded.

53 Exp.ps. 1184.25 (CSEL 62, 79.10-25): "Sed propheta, qui sincero conuerti uoluit affectu, 'uiam,' inquit,' 'ueritatis elegi; iudicia tua non sum oblitus.' non potest hoc dicere qui errat in dogmate, non potest Arrianus dicere, non potest Sabellianus, non Manicheus; non potest dicere auarus, qui saecularia et materialia concupiscit, non potest dicere qui negotiatur; non est enim uia ueritatis habendi studium, cupiditas possidendi. quomodo uia ueritatis, cum ille diues in saeculo nequeat secum suas transferre diuitias et incipiat mendico illo Lazaro egentior esse post mortem? non est uia ueritatis honor saeculi, sollicitudo mundi. denique, qui uiam ueritatis elegit, paulo post dicit: 'auerte oculos meos, ne uideant uanitates.' uanitas temporalium est, ueritas aeternorum. si uolumus igitur ambulare uiam ueritatis, peregrinemur saeculo magis quam deo et ambulemus per fidem. qui enim per fidem ambulat deo praesens est, qui ambulat per speciem adest saeculo, peregrinatur a domino; sed hic cito confunditur." 
Because Christ is both way and life, the way is life for us and we must seek the way so that we may deserve to have 1ife. ${ }^{54}$ Furthermore, we must walk according to the teachings of the law, because for us the law of God is the way. ${ }^{55}$ The one way that is the law is also many paths; there are many commands, many forms of justice, but the end of all these paths is Christ, for he is justice and he is the way: ${ }^{56}$

It is the way of the law to stand in the ways of the law; it is the way of just judgments, according to the first verse [Ps. 119.33]. Then it is also the way of testimonies: "I have delighted in the way of your testimonies" [Ps. 119.14]; it is also the way of commands: "I have run the way of your commands" [Ps. 119.32]. Then let us question these ways, so that it may be said of us, "stand in the ways of the law and question the enduring paths and see which way is better and walk in it" [Jer.

54 Exp. ps. 1185.1 (CSEL 62, 82.16-8): "et ideo, quia uia etiam uita est secundum illum, qui ait: 'ego sum uia, ueritas et uita,' uiam quaeramus, ut uitam habere mereamur."

55 Exp.ps. 1185.6 (CSEL 62, 85.24): "ambulemus igitur secundum legis doctrinam, uia nobis lex dei sit."

56 Exp. ps. 118 5.23-4 (CSEL 62, 94.1-17): "est legis uia stare in uiis legis, est uia iustitiarum secundum primum uersiculum. est ergo et testimoniorum uia: 'in uia testimoniorum tuorum delectabar'; est et uia mandatorum: 'uiam mandatorum tuorum cucurri.' interrogemus ergo has uias, ut dicatur nobis: 'state in uiis legis et interrogate semitas aeternas et uidete quae uia melior et ambulate in ea.' cum omnes igitur ambulauerimus uias, ueniemus in omnium finem uiarum, qui ait: 'ego sum uia.' Christus ergo finis uiarum; ipse est enim 'finis legis ad iusititiam omni credenti.' hinc audeo dicere, quia finis iustitiarum Christus, qui est iustitia, finis testimoniorum christus, de quo dictum est: 'estote mihi testes, et ego testis, dicit dominus, et puer meus quem elegi.

Aduertimus igitur, quantum nobis ambulandum sit, ut ueniamus ad Christum, ambulandum in lege, quia finis legis est Christus." 
6.16]. So, when all of us have walked the ways, let us come to the end of all ways, who says, "I am the way." Therefore, Christ is the end of the ways, for he himself is "the end of the law for the [obtaining of] justice for all who believe" [Rom. 10.4]. For this reason I dare to say that the end of just judgments is Christ, who is justice; the end of testimonies is Christ, about whom it has been said, "be witnesses for me, and I am a witness, says the Lord, and my servant whom I have chosen" [Is. 43.10].

Let us note, therefore, the extent to which we should walk so that we may come to christ, the extent to which we should walk in the law because Christ is the end of the law.

one who is on God's path does not even see the vain things of the world because the way that is christ is perfect. In order, then, that we may be on that path, "let us turn our eyes away from vanities lest what the eye sees, the soul lusts for. ${ }^{57}$

The one who walks in this new life, who treads the path of justice, is in partnership with christ, a companion on the way: ${ }^{58}$

57 Exp.ps. 1185.28 (CSEL 62, 97.8-9, 11-3): "etenim qui in uia est dei, uanitates non aspicit; uia perfecta Christus est. . . - auertamus igitur oculos nostros a uanitatibus, ne, quod oculus uiderit, animus concupiscat."

58 Exp.ps. 118 8.53 (CSEL 62, 183.13-5, 17-8, 184.411): "Sequitur uersus septimus: 'particeps ego sum omnium timentium te et custodientium mandata tua.' habet et Christus participes atque consortes sui. . . . habet participes carnis, quia carnem suscepit. . . . habet consortes baptismi, quia baptizatus pro nobis est, habet consortes iustitiae, quia ipse iustitia est et nobis de suo dedit sui habere consortium; habet consortes ueritatis, quia ipse ueritas est et nos tenere uoluit ueritatem: habet consortes resurrectionis, quia ipse est resurrectio, habet consortes inmaculatae uitae, quia ipse inmaculatus est, et quicumque in nouitate uitae ambulauerit, quicumque iustitiae tramitem tenuerit, particeps christi est." 
Verse seven [Ps. 119.63] follows: "I share with all those who fear you and keep your commands." Christ also has those who share with him and those who are partners with him. . . He has those who share in the flesh because he took on flesh. . . He has partners in baptism because he was baptized for us. He has partners in justice because he is justice, and he gave us of his own so that we might be in partnership with him. He has partners in truth because he himself is truth and he wants us to hold on to the truth. He has partners in resurrection because he himself is resurrection. He has partners in the unstained life because he himself is unstained, and whoever has walked in newness of life, whoever has kept to the path of justice is one who shares with christ.

Given Ambrose's emphasis on the centrality of scripture and the pervasive metaphor of the way, it is not surprising that his exegesis of Psalm 119.105 ("Your word is a lamp to my feet and a light to my path") is a lengthy one (Exp.ps. 118 14.1-13). For Ambrose, the words of scripture are the lamp that enables us to see the true way and follow it through the darkness to the light. ${ }^{59}$

Therefore, 60

59 Exp.ps. 11814.5 (CSEL 62, 300.21-5): "pascitur et oculus noster interior lucernae spiritalis lumine, quae nobis in hac mundi nocte praelucet, ne sicut in tenebris ambulantes incertis titubemus uestigiis et uiam ueram inuenire nequeamus. intellegibilis igitur pedum gressus, intellegibilis et lucerna, quia uerbum dei lucerna est."

60 Exp. ps. 11814.11 (CSEL $62,306.1-6,9-10$ ): "Sequamur ergo lucernam hanc sicut lucernam et sicut in nocte ambulemus ad lumen. multae foueae, multi scopuli in istius saeculi caligine non uidentur. praefer tibi lucernam quam propheta monstrauit, uide quo debeas transferre uestigium, contuere ubi pedem ponere mentis internae. per singulos cura sit gressus, nulli credas tuum nisi praeeunte lucernae istius luce processum. . . . sit ergo tibi fides itineris tui praeuia, sit tibi iter scriptura diuina; bonus est caelestis ductus eloquii." 
let us follow this lamp just like a lamp, as if we are walking in the night toward the light. Many pitfalls, many steep cliffs are not seen in the darkness of this world. Hold out in front of yourself the lamp about which the prophet taught; see where you ought to shift your footstep; regard attentively where to place the foot of your inner mind. Let the concern be for the individual steps. Do not entrust your progress to anyone unless the light of that lamp goes before it. . . . Therefore, let faith go before you on your journey; let divine scripture be the route for you. The guidance of the heavenly promise is good.

\section{Gathering the secrets of wisdom}

Christian wisdom is the way of life the christian is called to lead. It is a way of moral action, of faith, of a certain kind of knowing, all anchored in scripture and the understanding of God's word, an understanding given by God the word to those who believe and study carefully. The certain kind of knowing is almost entirely moral knowledge of what is to be done and how to do it; it is what practical reason knows. The sort of knowledge that speculative reason seeks lies within the domain of faith in the revelations recorded in scripture and interpreted and taught by the church.

In Ambrose's view, the proper task of speculative reason is to discover divine mysteries, the secret things of God, and "only the human being, among all earthly creatures, gathers the secrets of wisdom by listening and 
reflection and good sense."61 Ambrose's understanding of Christian wisdom is clarified by exploration of the epistemological terms -- auditus, meditatio, prudentia -he uses in that statement.

To begin with, in scripture auditus is instrumentally connected to obedient faith. In Psalm 18.44, the psalmist claims that "people whom I did not know have served me; in the listening of their ears they obeyed me." 62 From Isaiah's question, "Who has believed what we have heard?" Paul draws the conclusion that "faith comes from what is heard, and what is heard comes through the word of Christ." ${ }^{63}$

The contrast Ambrose draws between hearing, in its scriptural sense as a metaphor for reception by faith, and seeing, as a metaphor for the exercise of human reason, was mentioned briefly in chapter three (n.19). In his commentary on Luke's gospel, the need to dispel

61 Exam. 6.67 (CSEL 32.1, 255.11-3): "secreta sapientiae solus homo ex omnibus generibus quae in terris sunt auditu et meditatione et prudentia colligit . . "

62 Ps. 17.45 (Vulgate): "populus quem non cognovi servivit mihi; in auditu auris oboedivit mihi."

63 Is. 53.1 (Vulgate): "quis credidit auditui nostro."

Rom. 10.16-7 (Vulgate): "Esaias enim dicit Domine quis credidit auditui nostro. ergo fides ex auditu, auditus autem per verbum Christi."

Similarly, Gal. 3.2, 5 (Vulgate): "hoc solum volo a vobis discere: ex operibus legis spiritum accepistis an ex auditu fidei . . - qui ergo tribuit vobis spiritum et operatur virtutes in vobis ex operibus legis an ex auditu fidei."

The passage from Isaiah is also cited in John 12.38. 
controversy by faithful acceptance of the fact of the

Son's generation leads Ambrose to draw the distinction between seeing and hearing: 64

Although the human mind is not able to grasp it [the Son's divine generation] by the investigation of full reason, yet the fullness of faith

comprehends it. For even if it is not permitted me to know how he was born, nevertheless it is not permitted me to be ignorant of the fact that he was born. I do not know the order of the generation, but I know the source of the generation. We were not present when the son of God was born from the Father, but we were present when he was declared the Son of God by the Father. If we do not believe God, whom do we believe? For everything that we believe we believe either by seeing or by hearing. vision is often deceived; hearing is in faith.

Meditatio, as Ambrose uses the term, can be generally understood to mean reflection or contemplation, with the object of that mental and spiritual exercise being scripture or, more specifically, divine law (for example, Exp. ps. $11812.5,29 ; 13.7-8)$. In most instances, one can also read into Ambrose's use of meditatio the sense of

64 Exp. evang. sec. Luc. 4.71 ( "Quam licet mens non queat humana plenae rationis inuestigatione conprehendere, fidei tamen plenitudo conplectitur. Nam etsi non licet mihi scire quemadmodum natus sit, non licet tamen nescire quod natus sit. Seriem generationis ignoro, sed auctoritatem generationis agnosco. Non interfuimus, cum ex patre dei filius nasceretur, sed interfuimus, cum a patre dei filius diceretur. si deo non credimus, cui credimus? Omnia enim quae credimus uel uisu credimus uel auditu. Visus saepe fallitur, auditus in fide est." 
preparation and practice given to it by many classical authors. ${ }^{65}$

The following passage from the commentary on Psalm 119 encapsulates Ambrose's understanding of the meaning and importance of meditatio, here translated as "reflection," but clearly carrying the additional sense of preparation: ${ }^{66}$

Thus it says, "I have been reflecting on your commands which I have loved to the utmost; and I have lifted up my hands to your commands which I have loved to the utmost; and I have been trained in your judgments." Most excellent is that order, so that first we may reflect, and reflection on those precepts which we love may be habitual for us; certainly by reflection on heavenly commands the habit of good work becomes inveterate. For just as in reflection on words the goal is remembering, so that we may retain the words on which we reflect, so the effort or the purpose of reflection on heavenly precepts is work and performance directed toward fulfilling divine precepts which one cannot fulfill unless one loves them, and not only loves them, but loves them to the utmost.

65 Seneca, in one of his letters to Lucilius (Ep. mor. 54.2), speaks of the pain and discomfort of physical illness as a preparation for death: "Itaque medici hanc 'meditationem mortis' vocant; facit enim aliquando spiritus ille quod saepe conatus est."

66 Exp.ps. 1186.35 (CSEL 62, 126.10-20): "Ideoque ait: 'et meditabar in mandatis tuis quae dilexi nimis et leuaui manus meas ad mandata tua quae dilexi nimis et exercebar in iustificationibus tuis.' pulcherrimus ordo iste, ut primo meditemur et eorum praeceptorum, quae diligimus, sit nobis adsueta meditatio; meditatione enim mandatorum caelestium operis boni usus inolescit. nam sicut meditationi uerborum finis memoria est, ut quae meditamur uerba teneamus, sic meditationis praeceptorum caelestium intentio uel finis operatio est actusque directus ad implenda praecepta diuina, quae nisi quis diligat implere non poterit nec solum diligat, sed etiam nimis diligat." 
As for prudentia, Ambrose generally follows cicero in understanding this first of the principal virtues to be the capacity of good sense or discretion that enables one to distinguish between good and evil, ${ }^{67}$ a broad distinction that encompasses and constrains, by emphasis on moral action and the foresight that makes it possible, more purely cognitive notions of truth and falsehood (Cicero, De off. 1.6.18-9). In Ambrose's discussion of prudentia in his De officiis ministrorum, he also makes clear that it is important to acknowledge and rely upon the source of such sagacity in God and God's word, as protection against the sort of futile and obscure speculations that preoccupy pagan thinkers (1.122-5)

The passage in Exameron (6.67) that includes the listing of auditus, meditatio, and prudentia also distinguishes, as Ambrose does at various other places in his writings, among different sorts of hidden things, secrets of the God who is Wisdom, to which each epistemological term can be applied separately and with some consistent specificity. Although Ambrose himself does not categorize these neatly, it is clear from his writings that for him listening and reflection and good sense are means of knowing that are useful for somewhat

67 Prudentia is thus defined by cicero in De finibus 5.23.67; in De natura deorum 3.15.38 and in De inventione 2.53 .160 , the distinction includes the adiaphora. In De officiis 1.43.153, the discernment is of what is to be sought and what avoided. 
different, though perhaps overlapping, subsets of things to be known.

There are mysteries -- like the order of creation -that are clearly revealed in scripture (and some also in nature) and are, therefore, available to those who listen, who hear the word of God. There are secrets -- like the nature of the Trinity and the practical meaning of divine commands governing human conduct -- that are more deeply embedded in scripture but are potentially accessible to faithful reason through reflection on scripture and the person of Christ. ${ }^{68}$ And there is arcane knowledge -like the dimensions of the universe -- that is inaccessible to human minds; because it is inaccessible, such knowledge must be either useless or dangerous. It is the task of prudent discernment then to determine what knowledge is attainable and what is not to be sought, Ambrose's variation on the classical definition of prudentia.

The wise of this world, who rely solely on human reason's ability to see, investigate, and judge -- the epistemological contraries to Ambrose's favored terms -cannot attain the wisdom available to those who are able to hear, reflect upon, and discern God's truth through God's gifts of Word and word, faith and understanding.

68 It is reasonable to conjecture that, for Ambrose, allegorical exegesis is a form of reflection on what is heard. 
Ambrose's epistemology is centered on Christ and scripture. Wisdom is not an accumulation of the idle imaginings and calculations of human reason, but a divine person, knowable through the written revelation of scripture and through faithful reception and adherence. Reason's speculative task then is to receive and understand that wisdom and what it chooses to reveal; reason's practical task is to learn from wisdom what is to be done, and then to do it. The truly wise person walks in the way of the Lord, in Christ, in God's law, with reason acting to recognize and stay within the path illuminated by the lamp of scripture and the light of Christ.

Christian wisdom is christ. Christ as the way and the life is the wisdom that informs and empowers human moral life. Christ as the truth and the fulfillment of the law is the wisdom that encompasses all the knowledge necessary for, accessible by, and permitted to human beings. Christ is the beginning and the end of the way of wisdom .

Reason enjoys its full usefulness, its created role as governor of the soul and the moral life, only when it is firmly rooted in the true beginning of all things -Christ, through whom all things were made -- and when it is directed toward the true end of all things -- christ, the fulfillment of divine law and the wisdom dwelling in 
the bosom of the Father. Only reason that is correct in its beginning and end can keep us on the true path, the path of moral action which ultimately brings us to a wise and blessed life in the presence of God.

within the limits of the way, within those fixed poles of beginning and end, both of which are identified with Christ, reason can be spoken of in much the way philosophy speaks of it. Philosophy's fatal error is not so much in its formulation of reason's activity along the way as in its ignorance of those defining poles that assure that the way is right and true, that the way is Christ. 
CHAPTER FIVE

THE ROLE OF EXEMPLA

\section{1. "Examples rather than precepts"}

If Christian wisdom is indeed a way of living, of being in the world, rather than a compendium of information about the world, then it follows that instruction in that wisdom would more closely resemble a map than a textbook. Christian formation would be based more on patterns that reveal what wise living may be than on lists of precepts that attempt to define the bounds of moral action and cognitive possibility. Ambrose's writings uniformly reflect this reasoning as he relies on the narratives of scripture, especially the lives of the Hebrew patriarchs, to generate and deepen his hearers' understanding of the way of true wisdom and the moral call of their faith.

In one of his earliest writings, De virginibus, composed of sermons preached in 376 or 377 , Ambrose signals this reliance on stories taken from scripture. Although he first uses his inadequacies as a teacher to explain his use of exemplary lives -- a humble prologue that will be echoed in the opening paragraphs of De 
officiis ministrorum -- the true advantages to teaching by biography follow: ${ }^{1}$

But because we are weak in advising and unequal to teaching . . . we have thought it better to instill examples rather than precepts. Certainly more may be achieved by means of an example, because what has already been done is considered to be not difficult, and what has been approved is considered to be useful, and what has been poured into us in succession by a kind of hereditary practice of ancestral virtue is considered to be sacred.

A roadmap proven to be accurate is more likely to help a traveler reach her destination via the chosen route than is a set of traffic rules, and the procession of spiritual ancestors compels us to join the journey that is Christian wisdom.

Ambrose does speak of divine precepts, the commands of God, and God's judgments, especially in his commentaries on the Psalms. However, in these references to rules, the substantives are almost always abstract collectives that Ambrose uses to make points about the truth of God's power and fairness and the necessity for human obedience. He rarely mentions any particular dictum, either as a springboard for teaching or simply as an example of praecepta divina. In his works there are no sermons and very few paragraphs that focus, for example,

1 De virginibus 2.2 (Cazzaniga 1948, 35.5-6, 8-13): "Sed quoniam nos infirmi ad monendum sumus et impares ad docendum . . exemplis potius quam praeceptis putavimus imbuendam: licet amplius proficiatur exemplo, quoniam nec difficile quod iam factum est aestimatur et utile quod probatum et religiosum quod hereditario quodam paternae virtutis usu in nos est successione transfusum." 
on an individual commandment from the Decalog or a specific moral teaching from the sermon on the Mount. Ambrose does not teach ethics as a catalog of moral rules, instituted by God and listed, in scripture. Rather, he teaches Christian wisdom -- the content of which is almost entirely ethical -- as a pathway revealed by the lives of exemplary ancestors, formed by God and recorded in scripture. ${ }^{2}$

Ambrose's understanding of the revelatory and pedagogical nature of the lives of the patriarchs is clear in his introduction to the sermon on Joseph, the "mirror of chastity." Even though Joseph's story teaches its readers about a more specific kind of virtue than do the stories of earlier patriarchs, whose lives exemplify a sort of generalized virtuousness, the lesson is nonetheless revealed through the medium of Joseph's life rather than in a condensed, derived rule about chastity: ${ }^{3}$

2 Testard 1989, 120: "Il s'intéresse essentiellement aux exempla. Il est relativement rare que l'évêque invoque un texte doctrinal pour en faire valoir la portée dogmatique ou même l'enseignement moral théorique."

3 De Jos. $1.1-2$ (CSEL 32.2, 73.1-5, 8-74.2): "Sanctorum vita ceteris norma uiuendi est, ideoque digestam plenius accipimus seriem scripturarum, ut dum Abraham, Isaac et Jacob ceterosque iustos legendo cognoscimus, uelut quendam nobis innocentiae tramitem eorum uirtute reseratum enitentibus uestigiis persequamur. . . . iustum est igitur ut, cum in Abraham didiceritis inpigram fidei deuotionem, in Isaac sincerae mentis puritatem, in Iacob singularem animi laborumque patientiam, ex illa generalitate uirtutum in ipsas disciplinarum intendatis animum. nam licet illa diffusiora, tamen ista expressiora sunt eoque facilius mentem penetrant quo magis circumscripta ac determinata 
The life of the holy ones is a pattern of living for the rest of us. Therefore, we are explaining more fully the subdivided sequence of the scriptures, so that while we are getting to know Abraham, Isaac, Jacob, and the other just ones by reading, we may, so to speak, follow with struggling footsteps the pathway of integrity disclosed to us by their virtue. . . . Therefore, it is right -- when you have learned the diligent devotion of faith in Abraham, the integrity of an untainted mind in Isaac, the remarkable endurance of soul and of sufferings in Jacob -- that you direct your soul out of that generality of virtues toward specific sorts of instructions. For although the former is more extensive, yet the latter are more clearly distinguished, and they enter the mind more easily because they are more delimited and defined. Therefore, let holy Joseph be set before us as a mirror of chastity.

In this instance, Ambrose designates the life of the patriarchs as the norma vivendi; more often, he uses the term exemplum to refer to such revelatory stories. ${ }^{4}$

Exempla serve two general functions in moral pedagogy: they may be illustrative or paradigmatic. Examples that illustrate already known concepts or precepts embody those ideas in ways that can enhance the explanation or inspire action. Paradigms, on the other hand, manifest morally and spiritually compelling ways of living that cannot be entirely reduced to dicta, but that may extend and

sunt. Sit igitur nobis propositus sanctus Ioseph tamquam speculum castitatis."

See also De Abraham 1.2 and De interpellatione 1.2.

4 Welter 1973, 13: "Saint Ambroise (+ 397) semble avoir été le premier dans l'Eglise occidentale à recommander l'emploi de l'exemplum dans la prédication et à le mettre lui-même en pratique dans ses sermons en recourant plus spécialement à l'exemplum biblique." 
complicate the meanings of old precepts or even generate new ones. 5

Ambrose's writings are rich in the use of illustrative examples, including many from sources other than scripture, especially those that embellish his descriptions of nature in the Exameron (Welter 1973, 23). However, it is the centrality of paradigmatic biblical exempla that truly characterizes Ambrose's thought and, more particularly, illuminates his understanding of the relation of scriptural truth and philosophical error.

The point is not simply that Ambrose is an early narrative theologian who resists encapsulating the revelations gleaned from exemplary scriptural stories in pearl-like sententiae, and instead prefers to let the complexities of the individual lives remain entire and contextual so that the paradigm may broaden his hearers' moral understanding. More important, Ambrose believes the exempla contained in the pages of scripture - in particular, of the Hebrew bible -- to be epistemologically prior to all philosophical moral formulations. This is

5. Hawley 1987, xili-xv. In the same volume Brown $(1987,5)$ discusses the profound significance of the revelatory qualities of those persons who mirrored God in their righteousness; and Coleman (1987, 212) says, "We should expect [saints] to stretch our ordinary notions of structured prudence and virtue." 
fundamentally what his charge of philosophy's "borrowing" from scripture means. ${ }^{6}$

Ambrose's assertions that philosophers took their ideas from scripture rarely state that specific philosophical formulas, arguments, precepts, or classifications were lifted as such from the pages of the bible. ${ }^{7}$ Rather, the recorded lives of the patriarchs taught the earliest philosophers the nature of a moral life, which they then distilled into didactic systems of thought. But, as explained in chapter three, philosophy's failure to maintain its rooting in scriptural narrative resulted in errors, some egregious, in those systems of thought, errors which Ambrose can correct by returning to the originating stories for clarification, enhancement, and amendment of philosophy's formulations. Moreover, as also explained earlier, his certainty that such philosophical systems are derived from scriptural

${ }^{6}$ Madec (1974c, 184) makes a similar assertion: "Son [Ambrose's] originalité serait plutôt de prétendre que les philosophes ont tiré leur 'théorie' de la 'pratique' d'Abraham, conformément à sa thèse sur le plagiat de la Bible par les philosophes." However, Madec ties this claim only to a brief related argument Ambrose makes against philosophy -- that it concentrates on dicta rather than facta -- and does not consider its expanded relevance for understanding Ambrose's basic view of philosophy's source and error.

7 An exceptional instance in which Ambrose does claim literal and not just conceptual priority to scripture is in attributing the origin of the key socratic phrase "Know thyself" to Deuteronomy 15.9 ("adtende tibi") and Song of Solomon 1.8 ("nisi scias te"), as he does in Exp. ps. 118 2.13-4 and elsewhere (see Courcelle 1974, 1:117-9). 
narrative means that they are, as it were, the intellectual property of Christianity and can, therefore, be reappropriated without fear or shame for Christian purposes. ${ }^{8}$

\section{De officiis ministrorum}

Reading De officiis ministrorum with these claims in mind clarifies both Ambrose's use and his modifications of Cicero's De officiis. De officiis ministrorum is the work in which Ambrose's perspective on the role of exempla in the Christian moral life and teaching is most clearly and persistently displayed, because it is in this treatise that Ambrose is conceptually and verbally bringing a wellknown pagan philosophical system into intimate contact with Christian doctrine. It must, therefore, have seemed essential to him to proclaim on every page, by one means or another, the primacy of the scriptural narrative.

In his other sermons and essays, arguments against philosophy's errant ways are usually triggered by an event in the life of the patriarch being extolled or by the

8 For example, Ambrose's conviction that the system of four principal virtues put forward by pagan philosophy was originally derived from the earliest philosophers' readings of patriarchal narratives legitimates his use of the fourvirtue schema in the allegorical exegesis of biblical chariots (De virginitate 111-4, De Abr. 2.54, De Isaac 65) and in his explanation of the discrepancies between the four beatitudes in Luke's gospel and the eight in Matthew's (Exp. evang. sec. Luc. 5.49, 62-8; these passages are noteworthy as the only instance in which Ambrose finds the cardinal virtues in the New Testament). 
interpretation of a verse; they arise somewhat at random and are dispatched relatively quickly. But, in De officiis ministrorum, Cicero's philosophy is Ambrose's constant companion, in all its attractive rightness and its dangerous wrongness. Over and over again, it has to be brought back to its source in scripture to have that wrongness eradicated or transformed so its rightness could be affirmed and transmitted. Moreover, the content of Ambrose's work shows that the restorative return to scripture is not a return to biblical precepts as such, but to the stories of the holy ones of the Hebrew bible, the exempla.

\section{a. Exempla as Ambrose's method}

steidle has said that, while the observation that Ambrose has replaced Cicero's pagan examples with examples from the bible is incontestable, the crucial significance of that "replacement" should not be missed. The status of Ambrose's exempla is quite different; they come from the very word of God and are thereby invested with a meaning and importance that far outstrip that of cicero's figures. Their significance is such that they form the actual core of Ambrose's treatise, to which theoretical remarks have been subordinated. 9

9 Steidle 1984, 20: "Bei meinen eigenen Interpretationen zu De officiis gehe ich nun zunächst von einem unbestrittenen Faktum aus: Ambrosius hat die den 
The analysis of De officiis ministrorum undertaken by Steidle $(1984,1985)$ is in direct response to Testard's charge (1974) of Ambrose's compositional incoherence and planlessness (see chapter one, pp.28-32). Steidle shows convincingly that Ambrose does indeed have a consistent organizing principle and plan -- the focus on scriptural exempla -- for the work, ${ }^{10}$ but steidle does not go beyond the methodological question to consider what the centrality of exempla implies for Ambrose's thought in a broader and more fundamental sense.

Testard's later study (1989) softens, but does not retract, his criticisms of Ambrose's deficiencies as author and moral theologian. He exonerates Ambrose, to a degree, for his literary failure by calling him a man of action, not of an intellectual temperament, who would rather present exempla than engage in theoretical

Gedankengang illustrierenden exempla der ciceronischen Schrift weitgehend durch biblische und zwar zumeist des Alten Testaments ersetzt. Aufgrund dieser Herkunft erhalten aber -- und die ist wesentlich -- die exempla von vornherein einen Sinn und eine Bedeutung, die grundverschieden ist von ihrer Bedeutung bei cicero. Da die Schrift Gottes Wort ist und Gott selbst in ihr spricht, so sind sie ungleich bedeutsamer als bei Cicero, ja sie bilden ebenso wie die Schriftzitate den eigentlichen Kern des Werks, dem sich die theoretischen Ausführungen unterzuordnen haben."

10 For steidle $(1984,21)$, the passage quoted earlier from De virginibus $(2.2$, see n.1) confirms his argument that biblical exempla are fundamental rather than ornamental for Ambrose's moral thought and teaching: "Es handelt sich also um ein durchgängiges Prinzip ambrosianischen Lehrens." 
speculation, who would rather describe than discuss. 11

Like steidle, then, Testard acknowledges the importance of exempla in relation to Ambrose's method, though the two commentators disagree about whether the reliance on narrative constitutes a conscious or successful design. However, again like steidle, Testard does not take that recognition further.

\section{b. Exempla as source of moral knowledge}

Testard is correct in noting that Ambrose would rather describe than discuss, but that preference is not simply attributable to his being a "man of action" who is not too adept at speculative thinking, as Testard would have it. Rather, Ambrose believes that the way of Christian wisdom and moral living has to be modelled and seen -- or described and heard -- in an exemplary life,

11 Testard 1989, 120-1: "Ces conditions de travail devaient être d'autant plus éprouvantes pour saint Ambroise qu'il n'était pas un tempérament intellectuel et que rien ne l'avait orienté de ce côté. Certes il était intelligent, certes il était cultivé, mais ses aptitudes et sa formation le promettaient et le préparaient, dans le sillage de son père, à occuper -- ce qu'il fit du reste -- de hautes fonctions administratives. Saint Ambroise était un homme d'action. - . Il s'intéresse essentiellement aux exempla. Il est relativement rare que l'évêque invoque un texte doctrinal pour en faire valoir la portée dogmatique ou même l'enseignement moral théorique. Peu porté à la spéculation, dans le De officiis en tout cas, saint Ambroise qui vise à traiter de morale pratique, campe devant ses lecteurs des personnages concrets . . . Il faut interpréter de la même manière cette méthode d'exposition ambrosienne qui consiste à décrire plutôt qu'à discourir . . ." 
and not constructed verbally in a list of rules or as an inanimate syllogistic system.

Ambrose begins his De officiis ministrorum with the assertion that the very act of venturing to teach at all is done in imitation of David's humility and reverence. By such emulation, the transmission of David's wisdom may be possible, a wisdom accessible to us through the sight of David the psalmist's words and the example of David the king's life, visu comperta atque exemplo. ${ }^{12}$

In roughly the first third of Book one, the exempla employed by Ambrose are as often illustrations as paradigms; at times the two functions overlap. The experiences of David and Susanna are original revelations of the importance of silence $(1.4 \mathrm{ff}),{ }^{13}$ while the lives of Isaac, Joseph, Moses, and Jeremiah serve as both

12 De off. min. 1.1-2 (PL 16, 23A-24A): "Non arrogans videri arbitror, si inter filios suscipiam affectum docendi; cum ipse humilitatis magister dixerit: 'venite, filii, audite me; timorem Domini docebo vos.' In quo licet et humilitatem verecundiae ejus spectare et gratiam. . . . Et nos ergo ad imitandam verecundiam seduli, ad conferendam gratiam non usurpatores, quae illi spiritus infudit sapientiae, ea per illum nobis manifestata, et visu comperta atque exemplo . . .

13 The importance of silence is that it signals reliance on one's good conscience, as known by God. The function of conscience for Ambrose, as for many classical thinkers generally, is a retrospective one with only indirectly prospective implications. A thorough analysis of Ambrose's understanding of conscience, especially in its apparent role as evaluator of the soul's unity (i.e., of the extent to which behavior reveals reason to be coincident with the indwelling imago dei), goes well beyond the scope of Testard's germinal essay (1973) and of this dissertation. 
"evidence and proof"14 of items from the list of duties incumbent upon good young people (1.65-6). As Ambrose moves toward the extended exploration of the cardinal virtues that forms the major part of Book one, the paradigmatic function of exempla becomes paramount.

Both the precept-generating power of scriptural narrative and its temporal priority are displayed in 1.94, where the subject is the importance of not responding in anger to provocation: ${ }^{15}$

The gentiles, as they are in the habit of exalting everything in words, exaggerate the saying of the philosopher Archites of Tarentum, which he spoke to his own foreman: "O, you unfortunate man, how I would torment you if I were not angry!" But David also had already, in indignation, restrained his armed right hand. And how much greater is it not to return abuse than not to avenge oneself? And Abigail by prayer called back the warriors prepared for vengeance against Nabal. Whence we observe that we ought not only to yield to timely interventions but also to be pleased by them. It was so pleasing to David that he blessed her who intervened because he was called back from his zeal for revenge.

14 Steidle 1984, 35: "bezeichnend ist dabei wieder die grosse Rolle der exempla, die in 1,66 als Beleg und Beweis für das in 1,65 Gesagte dienen."

15 De off. min. 1.94 (PL 16, 52A): "Ferunt gentiles, ut in majus omnia verbis extollere solent Architae Tarentini dictum philosophi, quod ad villicum suum dixerit: 0 te infelicem, quem afflictarem, nisi iratus essem! sed jam David et armatam dexteram in indignatione compresserat. Et quanto plus est non remaledicere, quam non vindicare? Et bellatores adversus Nabal ad ultionem paratos, Abigail deprecatione revocaverat. Unde advertimus tempestivis quoque intercessionibus non solum cedere nos, sed etiam delectari oportere. Eo usque autem delectatus est, ut benediceret intervenientem, quod ab studio vindictae revocatus foret." 
The phrase, "Whence we observe that we ought," ties the exemplary story to the moral teaching that has been derived from it and expressed in reduced form as a sort of precept. The story does not illustrate the precept; it reveals it. ${ }^{16}$

The revelation of such moral truths to later readers and hearers of patriarchal biographies is at least one of the reasons God acted with those men as God did. Ambrose speaks, for instance, of "father Abraham himself, who was molded and educated for the instruction of generations to come. "17 This description is located in the midst of Ambrose's catalog of biblical exemplars who expand the meanings of the basic philosophical dicta that passion must be subject to reason and that moderation is crucial to the moral life (1.105-114). The coda to this section, and the transition to the next, is Ambrose's rhetorical question: "What duty of the principal virtues was lacking

16 It should be clear that Ambrose has no anachronistic concern for the modern stricture against deriving a prescriptive statement - an "ought" -- from a descriptive statement -- an "is." He is convinced that the divine formation and inspiration of these exemplary lives make them transparent windows into God's intentions for human conduct, and that God's intentions are the only reasonable basis for any prescription.

17 De off. min. 1.107 (PL 16, 53C): ". . ipse pater Abraham, qui ad magisterium futurae successionis informatus et instructus est.. ." (See Berton 1980, 313). Ambrose also speaks of solomon as having been "offered to us for the sake of example" in 2.53 ( $\mathrm{PL} 16,117 \mathrm{C})$ : "Exempli causa propositus est nobis salomon. . ." 
in these men?" ${ }^{18}$ What then follows is the clearest demonstration of Ambrose's understanding of the paradigmatic, generative power of scriptural exempla: his use of biblical narrative as the norma vivendi against which to affirm, expand, and correct the philosophical schema of the four cardinal virtues (see steidle 1984, 42; Stelzenberger 1933, 368-9).

Ambrose does not claim in De officiis ministrorum that philosophers have borrowed the four-virtue outline itself from scripture. ${ }^{19}$ At one point $(2.48-9)$ he attributes the classification instead to "common belief," in a passage that imitates but changes the sense of Cicero's similar claim to be bowing to popular understanding (De off. 2.10.35). Both authors begin by saying that wisdom cannot exist without justice, a truth which Ambrose locates in scripture, "which is older," in the story of Daniel. Cicero then says that he speaks to popular audiences in the language of the common people, who are in the habit of calling one person brave and

18 De off. min. 1.115 ( $\mathrm{PL} 16,57 \mathrm{~A}):$ "Quod his viris principalium virtutum officium defuit?"

19 Ambrose seems to make such a claim once in an earlier work, De paradiso. In that instance, the source for the four-virtue structure is purported to be the four rivers of paradise, mentioned in Genesis 2.10-4. Ambrose, following Philo, reads the rivers as the virtues, arising from Wisdom, and asserts that "the wise ones of this world have copied into the writings of their own books what was usurped from ours." (De par. 14 [CSEL 32.1, 273.24-6): "quae etiam sapientes istius mundi ex nostris adsumpta in suorum scripta librorum transtulerunt.") 
another wise, as though the virtues could exist separately, whereas he and his fellow philosophers, occupied with delving into the truth, understand that a person with one virtue has all. Ambrose, on the other hand, despite finding the co-existence of the virtues in scripture, defers to the popular division because he wishes to avoid precisely the philosophical delving that he consistently condemns: ${ }^{20}$

Therefore, out of consideration for common belief, let us make this four-part division so that we may follow public usage and common meaning, while pulling back from that subtle dialectic of philosophical wisdom which, for the purpose of getting at the truth, is dragged forth as if from a kind of shrine.

20 Ambrose De off. min. 2.48-9 (PL 16, 116A-B): "Liquet igitur etiam secundum scripturam divinam, quae antiquior est, sapientiam sine justitia esse non posse; quia ubi una earum virtutum, ibi utraque est. Daniel quoque quam sapienter alta interrogatione fraudulentae accusationis deprehendit mendacium, ut calumniatorum sibi responsio non conveniret! . . .

Est ergo individuum sapientiae atque justitiae conturbernium: sed vulgi usu dividitur una quaedam forma virtutum . . Sit ergo nobis communis opinionis gratia quadrapartita haec facta divisio, ut ab illa subtili disputatione philosophicae sapientiae, quae limandae veritatis causa quasi ex adyto quodam eruitur, retrahentes pedem, forensem usum ac popularem sensum sequamur."

Cicero De off. 2.10.35: "sed ne quis sit admiratus, cur, cum inter omnes philosophos constet a meque ipso saepe disputatum sit, qui unam haberet, omnes habere virtutes, nunc ita seiungam, quasi possit quisquam, qui non idem prudens sit, iustus esse, alia est illa, cum veritas ipsa limatur in disputatione, subtilitas, alia, cum ad opinionem communem omnis accommodatur oratio. Quam ob rem, ut volgus, ita nos hoc loco loquimur, ut alios fortes, alios viros bonos, alios prudentes esse dicamus; popularibus enim verbis est agendum et usitatis, cum loquimur de opinione populari." 
Ambrose makes just one reference to one of the two biblical passages that enumerate the virtues, and then only to emphasize the connection between them and wisdom rather than to claim scripture as the source of the tetrad. ${ }^{21}$ Instead he offers the lucid and revelatory exempla maiorum found in scripture as a mirror for education and a template for emulation of the virtues: ${ }^{22}$

We, however, avoid artfulness; we set forth instead the examples of our ancestors, which present neither uncertainty in regard to what is to be understood, nor guile in what is to be discussed. Let the lives of our ancestors, therefore, be for us a mirror for learning, not material for clever commentary. Let there be reverence in imitating them, not subtlety in discussing them.

Immediately thereupon Ambrose presents Abraham as a paradigmatic example who shows us that prudence consists

21 The reference, in De officiis ministrorum 2.65, is to Wisdom 8.7: "And if anyone loves righteousness, her labors are virtues; for she teaches self-control and prudence, justice and courage; nothing in life is more profitable for mortals than these."

The other biblical mention of the virtues, also in the apocryphal literature, is 4 Maccabees 1.18; Ambrose does not refer to this passage here or in the part of De Jacob that is so heavily dependent on 4 Maccabees.

22 De off. min. 1.116 (PL 16, 57C): "Nos autem artem fugimus, exempla majorum proponimus: quae neque obscuritatem afferunt ad intelligendum, neque ad tractandum versutias. Sit igitur nobis vita majorum disciplinae speculum, non calliditatis commentarium: imitandi reverentia, non disputandi astutia." (See chapter one, p. 30). 
most basically in the knowledge of $\operatorname{God}^{23}$ not a criterion to be found in cicero's analysis of this virtue.

The argument from priority persists, as Ambrose locates the source of information about virtues in both the existence and the words of the patriarchs -- an echo of the visu comperta et exemplo (n.12) from the opening part of the book: ${ }^{24}$

Thus, our earliest people determined that prudence consists of the knowledge of truth (for which of them [the philosophers] were before Abraham, David, or solomon?), then that justice regards the fellowship of the human race. For David said . .

A more explicit charge of plagiarism of ideas later in Book One sustains the theme. After showing how Moses and Solomon exhibit fortitude and expand the virtue's meaning to include keeping harm away from others, Ambrose declares, 25

Therefore, whence either cicero, or even Panaetius, or Aristotle himself copied this is clear enough. Although earlier even than these two [Moses and Solomon], Job said.. .

23 De off. min. 1.117 ( $\mathrm{PL} 16,57 \mathrm{C}-58 \mathrm{~A}$ ): "Fuit igitur in sancto Abraham primo loco prudentia, de quo dicit Scriptura: 'Credidit Abraham Deo, et reputatum est illi ad justitiam.' Nemo enim prudens, qui Deum nescit."

24 De off. min. 1.118 (PL 16, 58B): "Primi igitur nostri definierunt prudentiam in veri consistere cognitione. Quis enim illorum ante Abraham, David, Salomonem? Deinde justitiam spectare ad societatem generis humani. Denique David ait: . ."

25 De off. min. 1.179 (PL 16, 76A): "Unde igitur hoc vel Tullius, vel etiam Panaetius, aut ipse Aristoteles transtulerint, apertum est satis. Quamquam etiam his duobus antiquior dixerit Job: . . " 
The remainder of Book one and, in fact, of the entire work is characterized by strings of biblical stories followed by a derived conclusion, a "therefore" phrase that prescribes some sort of moral action for the readers of Ambrose and of scripture. This pattern demonstrates that the stories do not illustrate the precepts in question but are understood by Ambrose to have generated the precepts. The narratives are the source of our knowing what is required of us or, in other words, they are the means by which God reveals to us the way of Christian wisdom.

God made Eve to be a helpmate for Adam; therefore, we ought to help one another $(1.134-5)$. Stories of Joshua and Elisha lead to the conclusion that faith is the basis of justice (1.139-42). In the midst of repeating what Cicero has to say about liberality, Ambrose amends the pagan philosophical understanding of the term by adding a specific requirement taught us by Job's life: ${ }^{26}$

And there is also the liberality of benevolence, just as if you cancel a debtor's note you hold by tearing it up, having received from the debtor nothing of what is owed. By his own example, holy Job advises us that we ought to do this.

After giving David's military experience as an illustrative example of the need to temper fortitude with

26 De off. min. 1.168 (PL 16, 72B): "Est etiam illa benevolentiae liberalitas, ut si quod habes debitoris chirographum, scindens restituas, nihil a debitore consecutus debiti. Quod exemplo sui facere nos debere Job sanctus admonet." 
prudence, Ambrose adds that fortitude also consists in greatness of soul, a defining characteristic revealed by Daniel when he was surrounded by lions. The concluding "therefore" phrase is not significantly different from its parallel teaching in Cicero (De officiis 1.23.79), but nonetheless signals the derivation of this part of fortitude's definition from biblical sources, a connection confirmed in the next paragraph in which Ambrose says that the source for Cicero's copying is clear enough (1.177-9, see $n .25)$.

One of Ambrose's oft-repeated stories about David is the tale of the king's humble silence in the face of curses from the son of shimei. In 1.235-7, he analyzes the story yet again, this time from the standpoint of its revelation of the on-going process of perfection in David who, "although perfect, sought something still more perfect." The conclusion: "We, therefore, ought to strive for that in which there is perfection, in which there is truth." 27 David's encounter with the son of Shimei has taught us this.

The discussion of blessedness with which Book Two begins soon adopts the same pattern. Stories about Moses, Aaron, and Elijah (2.10-4) reveal that "riches, therefore,

27 De off. min. 1.237 (PL 16, 93B): "sed tamen quamvis perfectus, adhuc perfectiora quaerebat."

1.238 (PL 16, 94A): "Illa igitur nobis expetenda, in quibus perfectio, in quibus veritas est." 
offer no support for the blessed life," a truth affirmed by the beatitudes which teach the corollary, that those things considered evils in this life are in truth aids to attaining blessedness. ${ }^{28}$ Ambrose agrees with Cicero (De off. 2.8 .30 ) that the love of others is essential, but bases the knowledge of this truth in the lives of Moses and David (2.31-9).

Similarly, Cicero's assertion (De off. 2.9.31, 10.36) that the admiration of others is the third criterion, after good will and confidence, for attaining glory is transmitted by Ambrose, but as a lesson learned from scripture: "But also a third point, concerning those considered worthy of admiration, seems to be derived from the example of Joseph, Solomon, and David." Ambrose then refers to the admirable lives of Moses, Daniel, and Joseph, ending with a characteristic conclusion: "Therefore, we discover that, in seeking advice, uprightness of life, setting an example in virtues, habits of benevolence, and the charm of courteousness add much."29 Joseph exemplifies all these characteristics

De off. min. 2.15 (PL 16, 107C): "Nullum ergo adminiculum praestant divitiae ad vitam beatam. Quod evidenter Dominus in Evangelio demonstravit dicens: Beati pauperes, quoniam vestrum est regnum Dei. . . . Itaque paupertatem, famem, dolorem, quae putantur mala, non solum impedimento non esse ad vitam beatam, sed etiam adjumento evidentissime pronuntiatum est."

29 De off. min. 2.56 (PL 16, 118A): "Sed etiam tertius locus de his qui admiratione digni aestimarentur, Joseph, Salomonis et Danielis exemplo decursus videtur." 
(2.79-85) and, therefore, serves as the very pattern of one able to be an adviser: ${ }^{30}$,

Therefore, such ought to be one who gives counsel to another, so that he may present himself to others as a pattern, for the purpose of being an example of good works, in teaching, in integrity, in dignity.

Joseph's instructive example is then reaffirmed and the lesson retaught in the life of Paul (2.87).

This systematic restoration of philosophical moral tenets to their original root in scripture, with the attendant affirmation and amendment of the teaching, continues throughout the rest of De officiis ministrorum (for example, 2.98-100, 104-6, 112-6, 144-9; 3.33-7, 53-6, $60-6,82-90)$. Ambrose is not replacing pagan stories with scriptural narratives in order to "Christianize" the presentation of Cicero's philosophy. He is returning that philosophy to its originating exempla or, as he puts it, to "true exempla": "Therefore, so that we may return to the purpose, I shall put forward not fictitious examples

2.60 (PL 16, 118C): "Advertimus igitur quod in acquirendis consiliis plurimum adjungat vitae probitas, virtutum praerogativa, benevolentiae usus, facilitatis gratia."

30

De off. min. 2.86 ( $\mathrm{PL} 16,126 \mathrm{C})$ : "Talis itaque debet esse qui consilium alteri det, ut se ipsum formam aliis praebeat ad exemplum bonorum operum, in doctrina, in integritate, in gravitate.."." 
instead of true ones, but true examples instead of fictions." ${ }^{31}$

Ambrose is thereby grounding pagan philosophy in what he is convinced is its genuine foundation, the base from which the truth which that philosophy contains can be legitimated, corrected, and taught appropriately and effectively. Ambrose would understand the process not as the superficial "Christianization" of an alien system of thought, but as the profound and essential redemption and reclamation of flawed philosophy, Christianity's "full brother" (De Cain 1.4; see chapter three, p. 108).

The final paragraph of Ambrose's moral treatise reiterates the reliance on exempla that he signals at the beginning (1.2), at paragraph 1.116, and implicitly throughout the work, the reliance that forms the propositum to which he returns each time his philosophical counterpart cicero occupies himself with fabulae or with the subtle dialectics of his trade. The "procession of

31 De off. min. 3.32 (PL 16, 154C): "Ergo ut ad propositum redeamus, non fabulosa pro veris, sed vera pro fabulosis exempla proferam."

The fabulosum exemplum Ambrose turns away from is Plato's story of Gyges. Similarly, in De Abraham, Ambrose uses Plato's Republic, along with Xenophon's Cyropaedia, as the fictitious foils against which to present the actual life of Abraham as worthy of study and emulation (De Abr. 1.2; see chapter three, n.31). 
ancient ones" is, like David and like Christ (1.1-3), the true teacher: ${ }^{32}$

These things I have entrusted to you, my sons, which you may keep carefully within your souls; you will show whether they have any benefit. For now, they present a large store of examples, for almost all the examples of our ancestors and, indeed, much of what they said are contained within these three books. So, even if the words carry no charm, yet the procession of ancient ones, portrayed in a sort of abridged version, may contribute a great deal of instruction.

\section{Beyond exempla}

De officiis ministrorum is the work that most clearly demonstrates Ambrose's conviction of the generative power of scriptural narrative and the Hebrew bible's role as the origin of pagan philosophy. As stated earlier, this is so largely because his choice of Cicero's De officiis as the system of moral thought along which to order his own work required constant justification and correction of that system by re-establishing it as one reasonably derived from the lessons embodied in the lives of the patriarchs. Among Ambrose's other writings, the sermons preached about

32 De off. min. 3.138 (L 16, 184B): "Haec apud vos deposui, filii, quae custodiatis in animis vestris: quae utrum aliquid profectus habeant, vos probabitis; interim copiam multam exemplorum offerunt: nam prope omnia Majorum exempla, plurima quoque dicta his tribus inclusa libris tenentur; ut et si sermo nihil deferat gratiae, series tamen vetustatis quodam compendio expressa plurimum instructionis conferat."

The idea that knowledge is granted through our connection with the series vetustatis is found also in Exp. ps. 1187.15 (see n.34). 
the lives of specific biblical figures not surprisingly make the same fundamental point: their lives teach us, by revelatory, paradigmatic example, how we are to walk the path of Christian wisdom. However, those works can demonstrate that essential epistemological argument without the need to draw continuous connections and contrasts with the flawed teachings of a philosophy that has grown away from its origins.

In the commentaries on the Psalms, which were written in the later years of Ambrose's ministry, the compelling, formative power of biblical stories is still acknowledged (for example, Explan. ps. 1 7, Explan. ps. 38 10). Even Job, one of the most frequently cited exempla in De officiis ministrorum (Baskin, 1981), was himself shaped by the paradigmatic lives recorded in scripture: ${ }^{33}$

How many things piled together so that by that affliction holy Job might be destroyed. But, because he was molded by the moral lives of the patriarchs and directed by instruction in heavenly prophecies and natural law, in such temptations, therefore, he could not be destroyed.

Elsewhere in the commentary on Psalm 119, Ambrose makes a similar statement about formation, one reminiscent of the pattern of De officiis ministrorum. In the preceding paragraph (7.14), he has listed three intentions

33 Exp. ps. 11812.29 (CSEL 62, 268.21-4): "Quanta simul coaceruata sunt, ut illa adflictione Iob sanctus periret! sed quia patriarcharum moribus informatus oraculorumque caelestium et naturalis legis erat institutione formatus, ideo in temptationibus tantis perire non potuit." 
or objectives of a holy man: to remember the heavenly promises, to console himself in the midst of troubles with the hope he has imbibed from scripture, and to hold to the law even when the wicked prosper: ${ }^{34}$

The fourth goal of a man is that he may remember the heavenly judgments, just as David claimed, who said, 'I have remembered your judgments which are of old and I have been comforted' [Ps. 119.52]. For unless each one who has been instructed in the law and molded by examples believes the judgments of God always to be true, he will quickly deviate from the law. But the man who recalls past examples and recollects the procession of ancient ones knows that sinners will not avoid the punishment for their wickedness nor just ones be cheated of the rewards of their just dealing.

This declaration is followed by brief reminders of the stories of Adam, Cain, Noah, Abraham, Jacob, David, and Elijah, all exempla whose lives have revealed the truth of eventual punishment and reward.

Although Ambrose's belief in the epistemological priority of biblical narratives for both pagan and Christian moral thought is consistently detectable in the later writings, the emphasis in these works shifts to two other interconnected uses of the concept of exemplum. First, Christ is now presented as the premier example for

34

Exp.ps. 1187.15 (CSEL 62, 135.27-136.6) : "Quartum propositum viri, ut memor sit iudiciorum caelestium, sicut Dauid adserit, qui dicebat: 'memor fui iudiciorum tuorum quae a saeculo sunt et me consolatus sum.' nisi enim unusquisque legis instructus et formatus exemplis credat semper uera esse dei iudicia, cito declinat a lege. qui autem praeterita repetit exempla et colligit seriem uetustatis, cognoscit, quod neque peccator poenam suae improbitatis euadat neque iustus aequitatis suae praemiis defraudetur." 
human beings, both in his moral perfection and because of his redemptive power. ${ }^{35}$ Second, Ambrose's exegeses stress the distinctions among the present shadow world, the image of God in Christ, and the truth of God's kingdom; examples, crucially useful as they are, are nonetheless part of the shadow.

\section{a. Christ, the perfect example}

In the commentary on Psalm 39, Ambrose begins by presenting Christ as wisdom and the way, and as the model most worthy of imitation by the person who would follow that way: ${ }^{36}$

For whether you seek wisdom or devote yourself to virtue, or to truth, or to the way, and to justice or resurrection, in all of these things you must follow Christ, who is the power and wisdom of God, the truth, the way, justice, resurrection. Then what do you strive for if not the perfection of all things and the highest virtue? And so he says to you, 'Come, follow me,' that is, so that you may deserve to attain the perfection of the virtues. Therefore, those who follow christ ought to imitate him, according to their own potential, so that they

35 Stelzenberger 1933, 498. The Christological emphasis of the commentaries on the Psalms is demonstrated and discussed by Auf der Maur (1977).

36 Explan. ps. 381 (CSEL 64, 184.7-15): "siue enim sapientiam quaeras siue uirtuti studeas siue ueritati siue uiae atque iustitiae siue resurrectioni, in omnibus tibi sequendus est Christus, qui est uirtus dei atque sapientia, ueritas uia iustitia resurrectio. ad quem igitur contendas nisi ad perfectionem omnium summamque uirtutum? et ideo tibi dicit: 'ueni sequere me,' hoc est, ut ad consummationem uirtutum peruenire merearis. ergo qui sequitur Christum, ipsum pro possibilitate sua debet imitari, ut praecepta eius secum ipse meditetur et diuinorum exempla factorum." 
themselves may reflect inwardly on his precepts and the examples of his divine deeds.

Abraham was molded (informatus) by God (De off. min. 1.107; see n.17) so that we, his descendants and spiritual successors, might learn to live a righteous life. In Ambrose's thoroughly Nicaean Christology, such spiritual formation is mediated through the co-eternal Christ even in those who lived before the incarnation. But now, because the incarnation has occurred, we can also be shaped by christ, not only through the mediation of the exemplary patriarchs but through the life of the imago dei himself, as Ambrose explains in a passage that includes a summary of his Nicaean theology: ${ }^{37}$

You came to church; you heard God called one, whence the law begins, as it is written: 'Hear, Israel, the Lord your God, the Lord is one.' Believe God to be one, not many gods. But when you begin to read that the Lord Jesus, the son of God, came in the flesh for the redemption of the whole world, wisely perceive the distinction between the one God, who is the Father from whom are all things and us in him, and the one Lord Jesus through whom are all things and us through him. Know that he

37 Exp.ps. 11820.57 (CSEL 62, 473.3-15): "Uenisti ad ecclesiam, audisti unum deum dici, unde lex incipit, sicut habes scriptum: 'audi, Israel, dominus deus tuus dominus unus est.' Crede unum deum esse, non plures deos. cum autem coeperis legere dominum Iesum dei filium in carne uenisse propter totius mundi redemptionem, distingue sapienter unum deum patrem esse, ex quo omnia et nos in illum, et unum dominum Iesum, per quem omnia et nos per ipsum. cognosce quia ideo uenit, ut uirtutis semitis noster informaretur affectus, ut morum mansuetudinem conuersationis eius disceremus exemplo, ut aboleretur culpa per gratiam, et tunc a ueritatis confessione ad cognitionem iustitiae processisti. fides principium christiani est, plenitudo autem christiani iustitia est; fides in confessione populorum, iustitia in martyrii passione." 
came, therefore, so that our disposition might be fashioned in the paths of virtue, so that we might learn to be gentle in our behavior by the example of his way of life, so that guilt might be eradicated by grace; and, consequently, you have advanced from the acknowledgement of truth to the knowledge of justice. Faith is the beginning of a Christian, but the fullness of the christian is justice. Faith is in the confession of the peoples, justice in the passion of the martyrs.

The implications of the knowledge that human beings are created in the image and likeness of God form a recurrent theme in Ambrose's writings; he emphasizes that it is the soul (Exam. 6.39-46) or reason (Exp. evang. sec. Luc. 8.95, Exp.ps. 118 8.23), and not the body, that has been made in the divine image. But he also knows that Christ is the true imago dei (Exam. 6.41, Exp. evang. sec. Luc. 2.27), which then entails two consequences for human beings.

First, we have been made in the likeness of God; we are not really images of God, but are imitators of the true imago. In Expositio psalmi CXVIII 10.6-16, explaining Psalm 119.73 ("Your hands have made me and fashioned me; give me understanding that I may learn your commandments"), Ambrose discusses what it means to have been fashioned in God's image: the preciousness of even the human body, the loss of the image through sin (cf. De interpe11. 3.24). Then, given the acknowledgement of human sinfulness, the bishop declares that humans are made "according to" the image of God but are not actual images (cf. Exp. evang. sec. Luc. 10.49). Christ is the true and 
only image of God and he enables those of us who bear something of God's likeness within us, even those of us who have lost much of that resemblance by our sin, to receive the true image once again and be restored. ${ }^{38}$

second, not only by the grace of reception but also, and crucially, by following the example of Christ -- by imitating the image -- does one incorporate the imago into one's own soul. It is by a person's behavior that christ can recognize himself in that person (Exp. ps. 118 15.36). Works are both the evidence and the result of the image of God dwelling within: ${ }^{39}$

. . you are according to my image and likeness. There shines in you the image of justice, the image of wisdom, the image of virtue. And because the image of God is in your heart, let it be also in your works; let an imitation of the gospel be in

38 Exp. PS. 118 10.16 (CSEL 62, 212.25-213.4): "Si intellegas imaginem, uidebis ad imaginem; homo enim non est imago dei, sed ad similitudinem factus est. alius est 'imago dei inuisibilis, primogenitus uniuersae creaturae, per quem facta sunt omnia.' ille non ad imaginem, sed imago; tu non imago, sed ad imaginem. habes ergo in tua substantia aliquid de imagine et similitudine dei, quod sit diuinae simile imaginis. propterea imago ad eum, qui est ad imaginem, uenit et quaerit imago eum, qui est ad similitudinem sui, ut iterum signet, ut iterum conformet, quia amisisti quod accepisti. insufflauerat enim tibi deus, ut inspirationis suae dono haberes gratiam, quam tibi tua culpa sustulerat."

39. Exp.ps. 11822.34 (CSEL 62, 505.5-12): ". . . ad imaginem meam es et similitudinem. fulget in te imago iustitiae, imago sapientiae, imago uirtutis. et quia imago dei in corde est tuo, sit et in operibus tuis, sit effigies euangelii in tuis actis, ut in tuis moribus mea praecepta custodias. effigies euangelii erit in te, si percutienti maxillam alteram praebeas, si diligas inimicum tuum, si crucem tuam tollas et me sequaris. ideo crucem ego pro uobis portaui, ne tu propter me portare dubitares." 
your deeds, so that you may keep my precepts in your conduct. An imitation of the gospel will be in you if you offer the other cheek to one who strikes you, if you love your enemy, if you take up your cross and follow me. Thus I have borne the cross for you so that you may not hesitate to bear it for my sake.

\section{b. Exemplars in the shadow}

The coming of christ, the revelation of the true image of God in Jesus, has by its dazzling light cast all that came before and all that does not now reflect his brightness into shadow. The reality of Christ's imaging of God for us draws us out of the shadow and carries us toward the perfection of truth itself. Ambrose, especially in his later writings, returns often to the triple theme of shadow, image, truth to describe the temporal and spiritual progression of the individual soul and of the church. That the law and the patriarchs of the Hebrew bible are the shadow implies not only that they are in darkness when compared to the light of Christian revelation, but also that they foreshadow and represent, if only dimly, the truth to be known.

The first clause of Psalm 39.6 ("Surely everyone goes about like a shadow") evokes from Ambrose this meditation on shadow, image, and truth: ${ }^{40}$

40 Explan. ps. 3825 (CSEL 64, 203.6-16): "Primum igitur umbra praecessit, secuta est imago, erit ueritas; umbra in lege, imago uero in euangelio, ueritas in caelestibus. umbra euangelii et ecclesiae congregationis in lege, imago futurae ueritatis in euangelio, ueritas in 
Thus at first the shadow came before; the image followed; the truth will be. The shadow is in the law; the image surely is in the gospel; the truth is in heavenly things. The shadow of the gospel and of the coming together of the church is in the law; the image of the truth to come is in the gospel; the truth is in the judgment of God. Therefore, there was in the words of the prophets a shadow of those things which are now celebrated in the church. There was a shadow in the flood, a shadow in the Red Sea, because our ancestors were baptized in the cloud and in the sea; there was a shadow in the rock that flowed with water and followed the people. Was that which was in shadow not the rite of this sacred mystery? Was the water from the rock in shadow not like the blood from Christ which follows people fleeing him, so that they may drink and not be thirsty, may be redeemed and not perish?

In the commentary on Psalm 119, Ambrose explains that we remain in the shadow, but now that we know Christ and the gospel it is no longer the dimness of ignorance but the sheltering, embracing shadow of Christ, which transfigures and reveals the truth. When the realm of the shadow is contrasted to the bright truth, Ambrose prefers the term exemplar: ${ }^{41}$

iudicio dei; ergo quae nunc celebrantur in ecclesia, eorum umbra erat in sermonibus prophetarum, umbra in diluuio, umbra in Rubro Mari, quando baptizati sunt patres nostri in nube et in mari, umbra in petra quae aquam fluxit et populum sequebatur. nonne illud in umbra erat sacrosancti huius mysterii sacramentum? nonne in umbra erat aqua de petra quasi sanguis de Christo, qui fugientes se populos sequebatur, ut biberent et non sitirent, redimerentur et non perirent?"

41 Exp.ps. 1183.19 (CSEL 62, 50.27-51.9, 15-21): "In umbra igitur hic uiuimus et ideo in umbra custodimus uerba dei. et ut exemplo utamur, utique ante eramus sub umbra legis, quando custodiebamus neomenias et sabbata quae sunt umbra futurorum, sicut hodieque Iudaei, qui uerum sabbatum non uident, qui exemplari et umbrae seruiunt. nos quoque secundum euangelium nunc uiuentes umbram sequimur uerborum 
So here we live in the shadow and, therefore, in the shadow we keep the words of God. And, so that we may make use of an example, without doubt we were previously under the shadow of the law when we observed the new moons and sabbaths which are the shadow of things to come, just as even today the Jews do, who do not see the true sabbath, who are subservient to exemplars and shadows. In the same way we, now living according to the gospel, follow the shadow of the words of God. Nathanael is seen under a fig tree; David says that he hopes to be in the shadow of the wings of the Lord Jesus; Zachaeus climbs into a sycamore tree so that he may see Christ. In the same way, Jesus stretches forth his hands to us so that he might overshadow the whole world. How could we not be in his shadow, we who are protected by the veil of his cross? . . Therefore, just as [Christ] changed form when he was born from the virgin, so also the words of the transfigured God are seen by us, when they are read in the gospel, when their likeness is seen in the scriptures as if by means of a mirror, because the whole truth cannot be grasped here. But, when that which is perfect has come, no longer by means of descent, nor by means of a likeness, as of a transfigured person, but in whole and concrete truth let them [the words of God] shine forth.

Important as the patriarchs of the Hebrew bible are as exempla who provide a pattern of living that can keep Christians securely on the way of Christian wisdom, they pale in comparison with the transfiguring perfection of Christ's example. our spiritual ancestors were

dei. Nathanael sub arbore fici uidetur, Dauid in umbra alarum domini Iesu sperare se dicit, Zachaeus in arborem sycomori ascendit, ut christum uideret. nobis quoque expandit manus suas Iesus, ut totum mundum obumbraret. quomodo non sumus in umbra, qui crucis eius protegimur uelamento? . . . sicut ille ergo formam mutauit, cum ex uirgine nasceretur, ita et nobis sermones dei transfigurati uidentur, cum leguntur in euangelio, cum species eorum uidetur in scripturis quasi per speculum, quia tota ueritas hic non potest conprehendi. cum autem uenerit quod perfectum est, non iam per descensionem, non per speciem, ut transfigurati, sed integra atque expressa ueritate resplendeant." 
unquestionably formed and inspired by Christ and presage the truth to be revealed in the life and teachings of Jesus, but they are nonetheless shadows of the real thing. Unlike post-incarnation Christian saints, who can be understood to re-present Christ in their way of living (Hawley 1987, xv) and thereby become "Christ made accessible" (Brown 1987, 8), the patriarchs can take us only so far. ${ }^{42}$ The destination of the way of christian wisdom is Wisdom himself and only God's image, the Wisdom of God, can bring us to that goal. David understood the limitations of the exemplars within the shadow and asked Christ ${ }^{43}$ to bring him into truth: ${ }^{44}$

42 Ambrose refers at times to foreshadowings of Christ's teachings within the lives and words of the exempla maiorum, but rarely speaks of either the personages of the Hebrew bible or of particular events in their lives as types of Christ or of Jesus' acts. The prominent exception to this is Ambrose's sermon on the life of Joseph, who is consistently portrayed as a type of Christ, with Joseph's redemptive role in the history of Israel seen as prefiguring our redemption by Christ (see, for example, De Jos. 8, 14, 31).

43 Ambrose consistently uses dominus only when referring to Christ, deus only when referring to God the Father.

44 Exp. ps. 1183.25 (CSEL 62, 55.15-22, 24-6): "erat sub lege nutritus et sciebat, quia lex umbram habet futurorum bonorum; ipsa bona non iam per umbram, sed apertis oculis uidere cupiebat. nouerat, quia exemplari et umbrae caelestium mysteriorum seruiebant, qui secundum legem Moysi deseruiebant. uolebat ipsam cultus diuini conprehendere ueritatem et ideo, ut ab oculis suis uelamen discuteret, conuersus ad dominum precabatur dicens: 'adaperi oculos meos, et considerabo mirabilia de lege tua.' . . . quis enim de terrenis ad caelestia, de umbra ad claritatem, de exemplari ad penetralia ueritatis humano gradu sine diuino ductu possit ascendere?" 
[David] had been reared under the shadow of the law and knew that the law contains the shadow of good things to come. He desired to see those good things not just in the shadow, but with open eyes. He knew that those who are slaves to the law of Moses serve the exemplar and the shadow of the heavenly mysteries. He wanted to understand the very truth of divine worship and, therefore, so that he might shake off the veil from his own eyes, he turned to the Lord and prayed, saying, 'Uncover my eyes and I shall contemplate the wonders of your law' [Ps. 119.18]. . . For who can ascend by human steps, without divine guidance, from earthly things to heavenly, from the shadow to the light, from the exemplar to the innermost reaches of the truth?

The exempla maiorum provide us with a richly detailed pattern for living lives devoted to God and directed toward an eternity in God's presence. It is a pattern designed by God and lived out by people formed for that purpose through Christ, through whom all things were made. Moreover, that pattern, which was embodied and recorded before the first philosophers began to speculate on what a good life might be, taught those philosophers what they needed to know. The scriptural narratives formed the complex, living truth of good mores from which philosophers abstracted the verbal lineaments of the good Iife, the blessed life, lineaments of the sort transmitted by Cicero in his De officiis.

When the perfect life of Christ was revealed to us in Jesus, the lives of the patriarchs were affirmed -- and in no way negated -- as accurate representations of a life that is good by divine criteria, but they were also shown to be necessarily imperfect imitations relative to the 
perfect image seen in Christ. ${ }^{45}$ Following the model of their lives can help keep us in the way of Christian wisdom but, in the final analysis, that way is christ himself, and the achievement of the end of the way is possible only through christ, the perfect exemplum.

Philosophy, by divorcing itself from its source of moral knowledge within scripture, has not only lost the anchorage for its ethical teachings in the stories that could have kept those teachings honest, but has also missed the revelation of christ, without whom wisdom cannot be attained. One of Ambrose's tasks in De officiis ministrorum is to correct the former problem by returning philosophy's moral teachings -- as summarized by Cicero -to their roots within the exempla maiorum, whence they can be reclaimed by Christianity and amended by the stories themselves, which are now being read in full knowledge of Christ's perfect life and true teachings. The latter problem is handled in Expositio psalmi CXVIII, where the rootless, disputatious philosophical way of life is summarily dismissed in the face of the true path of divine wisdom, the way of Christ, who alone can bring us de exemplari ad penetralia veritatis.

45 Abraham, for example, is most consistently presented as a model of the proficiens, not as the vir perfectus (De Abr. 2.5; see chapter two, pp. 71-7). 
CHAPTER SIX

CONCLUSION

\section{Reading Ambrose}

\section{a. Ambrose and philosophy}

Goulven Madec's statement, ${ }^{1}$ the one that initiated and informed his book, saint Ambroise et la philosophie, is true: Ambrose is a disciple, of sorts, of certain philosophers while at the same time being an enemy of philosophy. But, contrary to Madec's interpretation, this assertion is not paradoxical. It may need explanation, but it does not need resolution or dissolution. Rather, the claim is a concise but densely packed characterization of the bishop's thought.

Ambrose is, most certainly, a disciple -- a student and, to some degree, a follower -- of Plato and his descendants, of the stoics, of the mixture of philosophical cosmologies and ethics that filled the intellectual air of fourth-century Rome and Milan, stirred by the rich inheritance of the writings of cicero and Seneca, Plotinus and Porphyry. Many of the French scholars who write about Ambrose's work describe him as impregne with this or that school of thought, and the metaphor is apt. Ambrose is deeply imbued with the

1 Madec 1974c, 12: "Ambroise serait donc un disciple de fait de philosophes et un ennemi de principe de la philosophie." See chapter one, pp.14-5 and n.17. 
strands of Stoicism and Neoplatonism that run through his educational and collegial milieu, and he brings those ideas and ways of thinking to fruition in sermons and essays that reflect his philosophical discipleship. But, the Bishop of Milan is also impregné with Christian belief and the stories of christian scripture. This equally deeply founded way of thinking, strengthened and informed both by his intense study after his election and by his responsibilities as pastor and preacher, similarly comes to fruition in sermons and essays that reflect his Christian discipleship. There are not twin sets of sermons and essays; rather, Ambrose's creations express the two primary influences on his thinking in a simultaneous and virtually indivisible manner, without being either incoherent or paradoxical.

Ambrose's argument against philosophy is not primarily an argument against particular philosophers or particular systems of thought, except insofar as they have erred in specific instances. Rather, he adamantly and consistently rejects philosophy per se as a way of life available as an alternative to the way of Christian wisdom. Recognizing that certain philosophers continue to express truths in a useful and accessible manner does not at all entail for Ambrose any level of acceptance of the philosophical systems which those thinkers espouse and promulgate. He can be a disciple of -- learn from -- 
those philosophers without any logical need to be a devotee or initiate of, or even to be tolerant of their philosophies, their aberrant ways of life.

\section{b. Ambrose's Christian philosophy}

Chapter one discussed Madec's limitations in method, specifically his failure to read Ambrose as Ambrose and his works as a whole, and his inaccurately narrow definition of fourth-century philosophy as the intellectual investigation of metaphysics rather than as also a way of life in pursuit of a moral ideal. It is these methodological and definitional constraints that seem to have blinded him to Ambrose's constant and clear presentation of the faults of philosophy and the nature of Christian wisdom. Despite Madec's recognition of Ambrose's "doctrinal dualism," his failure to glean from Ambrose's arguments against philosophy the bishop's comprehensive view of the composite "enemy" seems to be what makes it impossible for him to arrive at a coherent synthesis of Ambrose's understanding of the way of Christ, the Wisdom of God, although that path threads its way through the heart of virtually all that Ambrose wishes to say to his parishioners and clergy.

As described in chapter four, in contrast to the way of human wisdom, of non-Christian philosophy, for Ambrose the way of Christian wisdom begins and ends in God. While 
the beginning of wisdom is correctly equated in scripture with the fear of God, Ambrose points out that fear alone is inadequate (see pp.120-2). Entering upon and staying within the path of true wisdom also require knowledge, both experiential and cognitive, which can keep simple fear from falling into error. The fundamental source of knowledge is the word of scripture -- which can reveal both cosmological truth about God as creator and moral truth about the life of virtue -- as opened to the faithful reader by Christ the Word, who offers the key to knowledge (see pp.124, 128-34).

Faith in Christ -- faithful reception of and adherence to the word -- is the sine qua non of a life within the way of Christian wisdom because Christ is the Wisdom of God, because Christ is the way, and because the indwelling Christ illuminates human reason as it works to understand the revelation of truth embedded in scripture and in nature ${ }^{2}$ and to order behavior in accordance with that truth. The most important role of reason is, so to speak, to make the move of faith (see pp.138-40): to recognize the authority of the creator and of scripture, and to accept and receive Christ as the true imago dei, who can bring the believer's mind ever closer to identity with the image according to which it was originally

2 It is especially in the sermons that comprise the Exameron that Ambrose expounds on the revelation of truth available in the created world. 
created. Then, given this light of Christ suffusing the soul, human reason can and must go beyond a blind and potentially irrational reliance on the authoritative words of scripture (for ignorant reliance is the way fear without knowledge falls into error) toward an understanding and interpretation of those words.

It is this reasoned interpretation -- which Ambrose's commentaries themselves exemplify -- that unveils the riches of scripture's truths and makes them usable guides for individual behavior. That is, auditus must be accompanied by meditatio and prudentia, reason's discerning reflection on what has been heard (see pp.15762). In this task, reason is illuminated and guided by the presence of christ, accessible only through faith. Therefore, faith is both what enables entrance into the way of wisdom and what allows reason to see and stay within the path throughout the temporal course of one's life.

Ambrose would recognize the way of Christian wisdom as a philosophical way of life (see chapter one, pp.25-6 and n.29). At the level of word derivation, the identification of Christianity with philosophy entails only the recognition that, since christ is wisdom, then "love of wisdom" is most truly "love of christ" for the believer. However, Ambrose's understanding of the Christian life as a philosophical pursuit means more than 
that. The philosophical endeavor is a rational search for truth about the phenomenal and noumenal universe, about human nature and how human beings should live, and a reasoned effort to live by the light of that truth. Ambrose would say that non-Christian philosophers err in thinking that such truth can be invented by the freefloating speculations of human reason, no matter how complex and erudite, and that their error stems from their having forgotten that their original glimpses of truth, the glimmers that drew their intellectual ancestors into the philosophical journey, came from the revelations in ancient Hebrew scripture. True philosophy, then, recognizes that the source of truth is not human reason, but divine wisdom, revealed in scripture and in nature. Reason's speculative $\operatorname{task}^{3}$ is to discern that truth, a task that requires the sustaining and illuminating presence of Christ and the constant recognition of the divine source of all truth -- and both requirements entail faith. There is much for human reason to do in order to discover, understand, and act on revealed truth, but reason can accomplish those tasks only if it remains rooted in its divine source, in the word and the word. This summary of Ambrose's understanding of Christian wisdom (see also chapter four, especially pp.157, 163-4)

3 See chapter two, pages 47-52, for a more detailed exposition of Ambrose's views of the "purely intellectual" functions of reason. 
and its relation to pagan philosophy encapsulates themes that permeate his writings and that are sufficiently consistent and coherent to make such a synthetic picture possible as a faithful representation of his thought, but that stand out only in the course of a thorough, careful reading of Ambrose's writings. Such a reading requires not only attention to his educational and social background and the intellectual milieu in which he was formed and lived, but also a conscious effort to read Ambrose in the light of his own distinctive thought rather than in the shadow of either Augustinian theology or Ciceronian ethics. By that light, those writings -- from the exhortations to virgins to the directives to clergy, from the analyses of patriarchs' lives to the exegeses of Psalms -- reveal his consistent and richly nuanced understanding of Christianity as a conversatio, a way of living in Christ and, therefore, in a life of true wisdom and good moral action. His sermons and essays are all about how that life is constituted and characterized, based on those who have been proficient at it -- the almost perfect exempla of the Hebrew bible -- and on the one who has lived it perfectly, Jesus Christ.

Sometimes Ambrose finds that the interpretation of the narrative lessons of scripture is best expressed by philosophers whose teachings were originally formed by those stories: sometimes the philosophers' readings have 
to be corrected and expanded by recalling once again the germinal tales. Sometimes the Psalms help him explain the actions of exemplary figures; sometimes the reverse is true. And often the crucial story of Christ's love for the human soul, depicted in the romantic dialogue and imagery of the song of Solomon, can deepen and clarify the meanings of both the psalmist's injunctions and the patriarchs' actions. But all the exegeses and demonstrations of biblical truth that Ambrose weaves through his writings, whatever their provenance or method of interpretation, are presented for the purpose of teaching his hearers and readers how to live the wise and moral Christian life and what it means, morally and mystically, that christ is the way, the truth, and the life.

Within the bounds of that way of life, reason should perform much as philosophers say it should (see chapter two). God has given reason to human beings and the truth about its proper function, having been originally revealed in scripture, belongs to Christian wisdom as least as much as to merely human wisdom. Restoring the truth about reason to its source in scripture enables Ambrose to clarify the divine constraints on human reason that philosophers, having lost their grounding, have failed to recognize or chosen to ignore. Once the ways and limits of reason are clearly known, its beginning and end in God 
understood, then reason can serve as the essential faculty it was created to be, acting to discern the truth, to see the path, to keep one's thoughts and actions well within the boundaries of the way of christ, the path of true wisdom.

This understanding of the christian conversatio, of the role of reason, of the central moral nature of the way of wisdom, of the aberrance of philosophy, as well as of Ambrose's conviction of the temporal and epistemological priority of scriptural stories is displayed throughout Ambrose's writings and is most easily grasped when those writings are read carefully as an interconnected whole. Given this overarching picture of Ambrose's thought, the fundamental role of scriptural exempla becomes clear, as explained in chapter five, as does the way in which Ambrose himself would understand his use and amendment of pagan philosophical writers. This comprehensive idea of how Ambrose thinks and what he is about calls into question the metaphors used to explicate his relation to philosophical thought.

\section{c. Misleading metaphors}

In his discussion of Ambrose's work, Madec has said that Ambrose was extraordinarily adept at emptying words, particularly philosophical terms, of their original 
meanings and refilling them with his own definitions. 4 This metaphorical notion of words as essentially hollow and intrinsically meaningless vessels which can be filled and emptied by their users does not stand up to scrutiny, either generally as an intelligible metaphor or specifically as a descriptor of what Ambrose is doing. In the general sense, it seems clear that the notion that a complete evacuation of a word's meaning is possible is absurd. That is, to say that the word "justice" can now denote an article of furniture on which one sits is literally to speak nonsense. If the metaphor is not to be nonsensical, it must imply that some fundamental meaning of the word remains, that "justice" still signifies a concept recognizable as justice, even though details of its definition may be altered. Such modifications, of course, need not be trivial. In the example of justice, the word can continue to mean suum cuique, but a change in the interpretation of suum from "the same as everyone else" to "whatever one can take by force" would obviously mark a significant, even revolutionary alteration.

The issue for Madec, then, is not whether Ambrose "empties" philosophical words of their meaning, separating verba from res, to use Madec's terms. Ambrose clearly

4 Although Madec seemed to be thinking about and drawing evidence from De officiis ministrorum primarily, he applies his claim to the whole of the writings. See chapter one, pages 16-8, in reference to Madec $1974 \mathrm{C}, 175$. 
does not and cannot do this. The important question concerns the extent to which the meaning of a word is modified. To continue using the example of "justice," it is unlikely that cicero's followers would have failed to recognize that Ambrose was indeed talking about justice in De officiis ministrorum, and talking about it in ways quite familiar to them. Even in regard to the changes they might disagree with -- such as Ambrose's shift away from Cicero's explanation of private property toward an emphasis on property held in common because of God's common gift (De off. min. 1.132) -- they would still know that they were arguing about details within the definition of justice, not about whether such a debate belongs under the category of justice or not. The same point holds true if the word in question is temperantia, or ratio, or philosophia, or even sapientia. Thus, any discussion of how Ambrose has changed the meanings of classical terms has to demonstrate the specific changes and their significance, what is lost and what remains of the original understanding of the word in Ambrose's usage.

I would argue that Ambrose's verba retain much of the res associated with them in general and philosophical usage. That this is true can be demonstrated materially in Ambrose's writings (see, for example, the discussion of recta ratio in chapter two, pages 52-9) and sustained formally by the logic of Ambrose's thought: because the 
res -- the content of philosophical terms -- can generally be understood to have arisen from the ancient stories of scripture, it need not and should not be eliminated, but requires only correction and, at times, broadening to assure the accuracy and completeness of the verbum in question as an expression of the teachings of the source narratives.

A different metaphor, that of a building's framework, has often been used to portray Ambrose's modification of Cicero's De officiis; it, too, is problematic, and in much the same way as the verba-res figure. The construction trope does not suffer from the tendency to absurdity but does similarly beg the question of the extent and significance of the changes wrought upon the original structure. If it is true, as Hiltbrunner (1964; see chapter one, n.20) would have it, that the structure and its facade, as found in cicero's work, remain intact and that one has to step inside the house to see the changes that Ambrose's refurbishing has accomplished, then one could ask whether it is more important for the history of Western and Christian ethical thought that the house remains identifiably a three-story frame structure with all its original rooms, or that the art and furniture are now different.

In point of fact, the emphasis on the decorative changes, often stated as though scipio's picture over the 
fireplace were replaced by David's, ${ }^{5}$ obscures the essential truth of the metaphor: Ambrose believes that the house was built on land owned by the church, using blueprints and building materials found in the Hebrew bible. Even though the actual construction was done by philosophers, the divine contribution of land, plans, and lumber seals the claim to ownership; repossession is what is needed. In that process of reclamation, the furniture and art are indeed changed, restoring the furnishings to what was originally planned for the house, but those alterations should not overshadow the critical point that the place cicero called home has been declared to belong rightfully to Christianity. The structure itself does not need to be changed because it is of divine, scriptural origin. Only the later embellishments, added over the years by squatters who had lost the blueprints, need to be either demolished or altered.

Thus, the two metaphors used to describe the relation of Ambrose to philosophy, and specifically the relation of his De officiis ministrorum to Cicero's like-named work, have been employed in such a way that they have helped conceal the important process of repossession of both words and structure that Ambrose is about. I would argue

${ }^{5}$ This is the metaphorical equivalent of the claim that Ambrose has merely replaced Cicero's Roman examples with Christian ones. That this assertion is misleading in its superficiality and simplicity is discussed in chapter five. 
that many of Ambrose's interpreters have been susceptible to being blinded by their own metaphors not only because of limited methods of analysis and viewpoints colored by Augustinian or Ciceronian interests, but also because their unquestioning acceptance of the even more basic metaphor of borrowing has concealed from them the implications of Ambrose's insistence that philosophy found its truths in scripture.

The metaphor of borrowing is used in two senses in writings about Ambrose. In one, Ambrose is portrayed as one of the most vociferous of the early christian writers who charged philosophy with plagiarism, with having borrowed from the Hebrew bible whatever true things were to be found in philosophy's teachings and systems of thought. In the other, Ambrose is said to have borrowed from philosophy certain terms and systematic formulations, his use of which gives rise to the verba-res and framework metaphors discussed earlier.

In the first sense, the charge that philosophy has "borrowed" its truths from scripture, as explained in chapter three (p.104), implies the existence of one or more philosophical schools in parallel with scripture. Those schools are thought to have looted scripture, perhaps repeatedly, for ideas with which to enrich their own poor imaginings. Since truth is of God, anything deemed true within philosophy must have been stolen from 
the bible, and philosophy itself then contains a random mixture of false material of its own and true material not its own. Ambrose's insistence on the temporal priority of scripture is seen, within this metaphorical view, as mere repetition of the usual argument for greater credibility based on greater age.

The understanding of the relation of philosophy to scripture required by the borrowing metaphor not only is incorrect as a description of Ambrose's thought, but also conceals his actual idea of that relation. For Ambrose, the temporal priority of scripture is essential. Scripture antedates any philosopher known to us and no philosophical school can be considered to have developed in parallel with scripture. Instead, the earliest philosophical thought is grounded in and arises from the ancient stories of the Hebrew bible. Metaphors that speak of roots and fertile soil, or perhaps of springs and a river's headwaters, would capture Ambrose's thought more accurately.

This means that philosophy is not a random mixture of truth and falsehood, borrowed and original material. Rather, it begins in truth and many of its most basic concepts -- such as the necessary dominance of reason over passion -- are, therefore, true. The fraudulence of philosophy begins with the severance of its root in scripture and continues with its denial of the truth of 
God and God's creation. ${ }^{6}$ From that point on, further development and embellishment of its basic truths or the invention of new "truth" is fated to be false, as rootless philosophers get lost in their own intellectual meanderings and pointless dialectical debates. They are unable to find true wisdom, their true end, because they have lost their true beginning, the taproot that alone can nourish their thoughts.

Likewise, to speak of Ambrose as "borrowing" from philosophy when he uses terms and formulas that are clearly of philosophical origin is to misconstrue his relation to philosophical thought and, thus, to misunderstand his way of thinking altogether. Used by the same commentators who speak of Ambrose accusing philosophy of "borrowing" from scripture, the metaphor carries here the same misleading sense of a gap between parallel entities, in this case between Ambrose's mind and a philosophical tradition of thought, bridged temporarily at varying sites by a one-way process of exploration and looting. That is, the metaphor implies that Ambrose is situated entirely and only within the christian tradition of thought, however that tradition may be characterized in the fourth century. Further, it assumes that he is aware

6 Or, to use Ambrose's striking figure (originally Philo's) in De Cain 1.4 (see p.108), philosophy's falseness is apparent as soon as it leaves the womb it shared with its monozygotic twin, Christianity, and begins crediting itself with creative power. 
of the philosophical tradition of reasoning running in parallel with his own tradition and, upon investigation, finds within philosophy notions useful for and compatible with his own thought, and so appropriates them for use in his preaching and writing.

The borrowing metaphor is not the best trope to display Ambrose's relation to philosophy. Ambrose does not reason within the christian tradition only. It may not even be possible to identify such a rational tradition standing apart from other, equally discrete ways of thinking in the fourth century. But, even if it were possible, it is clear that Ambrose does not "borrow" from the world of philosophical thought, but reasons within it, even though he eschews the way of life termed "philosophy." 7 As explained in chapter one (pp.34-5), by virtue of his education and upbringing, his status within Roman society, the books he read as a student and continued to read as a bishop, it must be acknowledged that Ambrose is situated within the tradition of philosophical reasoning, if such a delimited tradition can

7 That is, Ambrose can reject philosophy as a false and dangerous conversatio, while continuing to display and teach ways of thinking that are recognizably philosophical. Madec's failure to grasp the important component of philosophy's definition as a way of life, rather than as only the intellectual pursuit of metaphysical knowledge, keeps him from making this distinction that is crucial to understanding Ambrose. 
be said to exist, just as solidly as he is within Christian thought.

once again, a metaphor of roots seems more revelatory of Ambrose's relation to philosophy. Ambrose is a thinker formed and continuously nourished by his roots both in classical learning and literature, and in Christian scriptures and teachings. It is plausible to say that he reads scripture with Plato's images, Plotinus' theories, Cicero's formulations in mind, and that he reads those philosophers and others with the deeds of Abraham, the words of David's Psalms, the life of Jesus filling his thoughts. And in each instance, he finds resonances, ways in which one explains, illuminates, even confirms the other. Of course, in cases of conflict, there is no question that scripture holds the upper hand; it can correct philosophy, but the converse is not true. However, even in such cases, the correction is another expression of his conviction that the truth in each is from the one true source, God.

\section{Ambrose's way}

\section{a. Traditions of reasoning}

Reading Ambrose carefully and thoroughly sheds light on the inadequacies and inaccuracies of the metaphors commonly used to explain his thought. Likewise, such a reading of this once-prominent apologist, promoter, and 
interpreter of Christianity illuminates the problems inherent in some theories concerning human reason and its constitution by seemingly delimited traditions of thought.

Alasdair MacIntyre (see chapter one, n.40) asserts that rationality does not exist outside the "debates, conflicts, and enquiry of socially embodied, historically contingent traditions" $(1988,350)$, that human reasoning is always and everywhere tradition-constituted and tradition-constitutive. He speaks of the process of "translation" that at times goes on between traditions of reasoning, specifically praising cicero for the conversion of Greek philosophical terms into Latin forms through which he could make ideas native to the Greek tradition of thought available to Roman thinkers $(1988,372)$. While MacIntyre's characterization of Cicero's particular task may be accurate, his more general theories about the process of "translation" between traditions are shaken by the example of a "traditionalist" like Ambrose.

MacIntyre claims that epistemological crises are inevitable within rational traditions. Such crises are brought on by the revelation over time of incoherences and contradictions within the tradition that cannot be answered satisfactorily by the tradition's own resources. The officials and interpreters of the tradition act to resolve the crisis by imaginatively inhabiting other, parallel rational traditions in order to discover within 
them new ideas and paradigms which can be integrated into the original tradition and resolve the crisis $(1988,349-$ 88). In short, MacIntyre's theory is an extended play on the metaphor of borrowing, portraying thinkers situated within parallel modes of thought who, from time to time, dip into each other's ideological storehouses for useful concepts and terms.

The problem with MacIntyre's theory is brought into focus by a thorough understanding of the thought of Ambrose, who certainly qualifies as an official and interpreter of the Christian tradition, by Macintyre's criteria. The problem is this: while MacIntyre may be correct that no one's reasoning can possibly be outside some tradition of thought and still be considered rational, he cannot assume that human beings, as a rule, inhabit fully only one tradition of thought and enter other traditions only partially, temporarily, and for cause. Ambrose is an example -- and surely not the only such example available -- of one who fully inhabits more than one tradition. ${ }^{8}$

8 Macintyre occasionally notes that persons can and do inhabit more than one tradition of reasoning fully and simultaneously; it seems experientially obvious that most persons do. However, his theoretical model of translation relies for its coherence on the assumption that humans reason within only one such tradition. The faultiness -or, better, the unreality -- of that assumption markedly constricts the theory's utility. MacIntyre does not speak of, nor offer a model for, the sort of reasoning that represents constant and mostly unconscious "translation" among the rational traditions at play within one individual. 
As discussed above, Ambrose does not "borrow" from the philosophical way of thought to enhance and clarify his own Christian way of thinking. He thinks both ways, as it were, simultaneously and with no hint that he experiences any internal splitting of his mental activity. Although one way of thinking, the Christian way, can be said to determine whether certain aspects or implications of the philosophical way must be jettisoned, nevertheless the modes of thought are inseparably intermingled in Ambrose's writings, as evidenced by the complex process of parsing necessary to identify tentatively what can be called philosophical and what christian in his works.

That Ambrose holds dual citizenship in philosophy and Christianity can perhaps most easily be shown by a thought experiment that imagines Ambrose as an inhabitant of the philosophical tradition of reasoning who "borrows" from Christianity and its scriptures certain ideas of the origin and end of wisdom in order to resolve epistemological -- or, perhaps, existential -- crises that have arisen within philosophy. If he can be seen equally well as standing within either christianity or philosophy and "borrowing" from the other to arrive at the views offered in his sermons and essays, then it is reasonable

The inextricable intertwining of traditions of thought within the minds of particular persons and, consequently, within their expressed thoughts is evident not only in Ambrose, but in thinkers who preceded and followed him. 
to assert that he reasons from a position within both traditions. Furthermore, one can extend and generalize this point to include the observation that neither the Christian nor the philosophical tradition in the fourth century were the clearly definable, separate entities that MacIntyre's theory requires, and to question whether such circumscribed traditions of thought can be said to exist at any point in human history, including the present.

\section{b. Narrative theology and ethics}

That Ambrose is a prototypical narrative theologian and theological ethicist is evident from his writings (see chapter five, p.169). The point can be made in two ways: first, Ambrose relies on the stories of scripture for their teachings about God and the moral way of Christian wisdom and, second, his sermons and essays not only retell those stories but are themselves examples of a narrative style. The first of these two points is the subject of chapter five, in which is described Ambrose's deliberate and consistent return to the biblical tales, which he believes to be the revelation of the nature of Christian wisdom and the source of all that is true in philosophical thought.

The second point, concerning Ambrose's narrative style, is an important part of the argument that one cannot read Ambrose adequately if one reads him in 
fragments (see chapter one, pages 20-2), for fragmenting his works obliterates the formal aspects that contribute significantly to an accurate and complete understanding of his thought. Ambrose's ideas are contained in lengthy and sometimes convoluted passages which move back and forth through scripture and among scripture, philosophy, and Ambrose's own synthesis of the two. Even when he is not explicitly telling or retelling a tale, his style remains that of a story-teller, as he weaves biblical and literary allusions into an extended play on the words of the biblical text or the events of the patriarch's life. His prolix developments are full of implicit meanings, of tangential references, and of the quintessentially narrative sense of something happening over time, be it in the life of the exemplum or in the believer's progress along the christian way.

Ambrose's consistency of thought is most clearly seen in this narrative style, the style that is typical of all his works and that expresses in itself his reliance on biblical stories and his conviction that the moral and intellectual life of a Christian is best understood as a journey along the path that is both modelled by and identified with Christ. Ambrose's literary form reflects the content of his thought, and both are narrative in their essence. This important relation of form and content has been well described by Nussbaum $(1990,5,6)$ 
in terms that speak clearly to what Ambrose accomplishes in his writings:

- . form and style are not incidental features. A view of life is told. The telling itself - the selection of genre, formal structures, sentences, vocabulary, of the whole manner of addressing the reader's sense of life -- all of this expresses a sense of life and of value, a sense of what matters and what does not, of what learning and communicating are, of 1 ife's relations and connections. Life is never simply presented by a text; it is always represented as something. . . .

The claim is that only the style of a certain sort of narrative artist (and not, for example, the style associated with the abstract theoretical treatise) can adequately state certain important truths about the world, embodying them in its shape and setting up in the reader the activities that are appropriate for grasping them.

Unless one perceives Ambrose's style as it is and for what it reveals, it is difficult to appreciate any of the central concerns that mark his writings and that have been displayed in detail in the preceding chapters. This is why Madec's decision to look at only extracted references to philosophy in the bishop's works and Testard's choice of only De officiis ministrorum (and that one work seen through the eyes of Cicero rather than Ambrose) for his analysis and judgment of Ambrose's thought led them to misunderstand Ambrose in so many important ways.

In one of his criticisms of Madec, Hervé Savon describes Ambrose as an "orator used to expressing his thought much less by lapidary formulas than by lengthy 
developments of a musical structure." 9 It is the musicality, the symphonic motion and complexity and tempo, that captures the narrative essence of Ambrose's style. One cannot hear Ambrose rightly if one does not attend to the music.

similarly, to return to the first point about his reliance on the teaching power of scriptural narratives, Ambrose could say that one does not hear scripture rightly (auditus) if one does not attend to its music. As noted in chapter five, Ambrose is much more interested in the importance of biblical exempla than in that of rules and precepts for revealing and guiding the moral life for faithful Christians. His notion of imitating and following the norma vivendi displayed in scripture is a narrative one; it has to do with aligning stories and journeys, with the musical sense of living one's life as a dance that is attuned to and faithfully expresses the melody revealed in scripture. The rules matter; they provide the boundaries and, perhaps, some paradigmatic behaviors that help characterize the dance. But the rules cannot constitute the movements or the grace of the life.

9 Savon 1977c, 187: "Et cela est plus vrai encore lorsqu'il s'agit d'un Ambroise, orateur habitué à exprimer sa pensée beaucoup moins par des formules lapidaires que par de longs développements à structure musicale."

It is likely that here Savon is thinking of the work of Lévi-strauss (1971) on the structuralist analysis of myths (in particular, the myth of Oedipus) as compositions of interwoven themes, arranged along lines suggestive of a symphony's orchestration. 
Hauerwas and Jones $(1989,5)$, in the introduction to their anthology of essays about narrative theology, put the point as follows: ${ }^{10}$

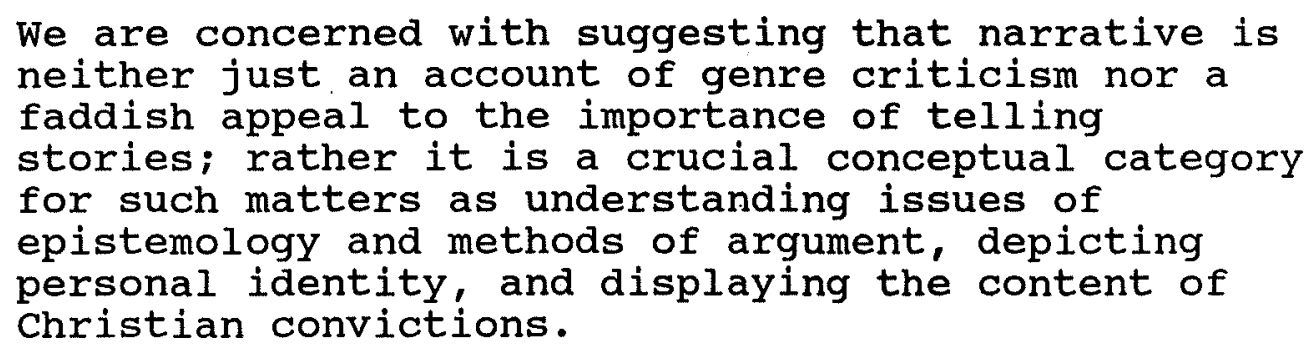

Recognizing and retaining the narrative form of Ambrose's writings and the content rich in stories are critical precisely for understanding his epistemology, his methods of argument, and his conception of human identity in relation to its perfect exemplar in christ, to the way of Christian wisdom, and to its beginning and end in God the creator.

c. Faith, ethics, and the role of christ

As discussed in chapter four (especially pages 13843), for Ambrose moral conduct, understanding scripture, and Christian faith are all interdependent aspects of the way of wisdom, the Christian conversatio, and cannot be considered separately witbout losing some of their coherence and meaning. While he could and did acknowledge the existence of truly moral behavior in particular

10 See also the discussion by Hauerwas and Burrell (1989) of the moral and pedagogical richness of narrative, and Frei (1974) on the consequences for theology of the loss of the appreciation of the narrative sense of scripture. 
persons who did not profess Christian faith, he was convinced that two things had to be true of such a person: one, the person's moral knowledge had to be originally derived, even if through the mediation of generations of teachers, from one who did possess faith, such as a biblical exemplum; two, absent a faithful recognition of and adherence to the divine source of moral wisdom, the person's moral excellence would not result in eternal life. The beginning and end of the Christian way, the only truly moral and wise way, is God and christ as God's wisdom and power. There cannot then be any intelligible separation of faith in Christ, an ethical life in christ, and knowledge of Christ through scripture.

In modern debates about the relation of christian faith to ethics, ${ }^{11}$ or of religion to morality generally, Ambrose would clearly be counted among those who claim that religious belief is determinative of moral belief and action, though that is to say too little. Similarly, he would likely accept the arguments of those who describe the relation of religion to morality as motivational, illuminating, and interpretive ${ }^{12}$, or as normative ${ }^{13}$ or

11. MacNamara (1985) presents a comprehensive historical view of the enquiry into the relation of faith and ethics. The second of Curran and McCormick's series on Roman Catholic moral theology (1980) is an anthology of essays that deal with the same issue expressed as the "distinctiveness" of Christian ethics.

12 See, for example, the discussion by Gustafson (1975, especially pages 173-9). 
even transformative. ${ }^{14}$ But, he would counter that all such portrayals are glaringly incomplete in their failure to attribute the very generation of all true moral understanding to God's revelation in scripture. The distinctiveness of Christian ethics is that it is the only true ethics; all others are false imitators which deny their divine origin and subsequent deviation.

For Ambrose, the crucial connection between faith and ethics is two-fold. First, faith in God entails faith in the truth and power of the stories of scripture which reveal to us the nature of a thoroughly moral life. There is no other way to know what is to be done and what is to be avoided than by faithful reflection on the word, a meditatio made possible by equally faithful reliance on the Word.

Second, faith in the Word is, therefore, what makes the Christian moral life itself possible. The role of Christ is central for Ambrose's understanding of ethics, as has been discussed. Again, while he would likely agree in principle with authors who speak of Christ as the norm

13 Especially às regards the figure of Christ; see von Balthasar $(1980,191)$ and Gustafson $(1968,264-71)$.

14 McCormick 1980, 170. In this regard, one could place Ambrose, along with Augustine, in H. Richard Niebuhr's category of theologians who understand Christ's role in relation to secular culture as one of transformation (1951, 190-229). This classification, however, like the others discussed above, truncates Ambrose's understanding of the complex interweaving of religious belief, the person of Christ, and ethical action. 
for Christian ethics, he would assert that they had missed the most important point about christ's relation to human morality. Christ is not just the pattern for the moral life; he is the way and the life. Christ is the Wisdom of God; therefore, the way of wisdom for Christians is Christ. Progress along that way requires mystical reception of Christ by faith.

For Ambrose, this mystical sense in which the faithful one receives, incorporates, and identifies with Christ is a crucial part of understanding how the Christian moral life is realized. The symbolism of the Song of Solomon is important for Ambrose and figures in so many of his interpretations of scripture because the imagery of sexual attraction and merger fits his understanding of the depth and seriousness of the inner mingling of the human soul and Christ (see, for example, chapter four, p.130). He frequently reminds his audience that Christ is the image of God, while human beings are only likenesses (see chapter five, pp.192-3), but the movement of his thought and his exhortations is toward the soul's becoming more nearly one with the imago dei, so that there is essential unity within the soul, with no longer any dissimilarity between the divinely created human reason and the divine image residing in one soul. And, as should be clear from the earlier parts of this chapter, the obvious philosophical resonances of such a 
vision of the soul's oneness in no way represent a contradiction within Ambrose's Christian teachings, since philosophy's truths belong to Christianity.

\section{d. The way of wisdom}

Taking Ambrose seriously as a theologian and theological ethicist -- as a Christian philosopher -means seeing more in him than the Kirchenpolitiker and the baptizer of Augustine, more than the student of Philo's exegeses and Cicero's ethics. All those roles help situate Ambrose accurately within the intellectual and ecclesiastical history that preceded and followed him, but they provide little reason for interest in his teachings today. In contrast, the broader portrayal of Ambrose's thought displayed in this dissertation suggests areas in which a consideration of his methods and reasoning could enrich current thinking in theological ethics.

Ambrose's emphasis on the generative role of biblical exempla deepens our understanding not only of the central importance of saints in the early church, but also of the ways in which Christian saints differ from pre-Christian holy persons. Even the most nearly perfect re-presenter of Christ's life cannot be paradigmatic in the same way as the patriarchs of the Hebrew bible, and not only because they are not early enough in time to claim credit for the truths of philosophy. 
The historical intricacies of the patriarchs' lives and the originality of their revelations give those figures a multi-dimensional complexity that both lends itself to Ambrose's exegetical methods and speaks to the realities of the lives of his hearers. There is a richness and an immediate human relevance in Abraham and Sarah's long and detailed travels, in David's ambivalent songs and soldiering, in Job's knotty suffering, that cannot be matched by the flatter pictures of Anthony in the desert or of Polycarp's martyrdom. The importance of this human complexity for Ambrose's task of teaching and exhortation gives support to present-day arguments, put forward by narrative theologians and ethicists, that there is more ethical information to be gleaned from authentic, lived human stories than a simple listing of derived precepts, caveats, and unresolved questions can comprehend.

Envisioning the moral life as a journey -- as the way of wisdom, to retain Ambrose's language -- emphasizes the spatial and temporal qualities characteristic of morality as it is lived, qualities that call for similarly solid ethical teachings. The one- or, at best, two-dimensional nature of moral "points" and prescriptions limits their role in the real venture of living to that of guideposts and boundary markers, or of lanterns and signal lights. Such a role is far from being unimportant, when one's goal 
is to remain well within the path, but punctual rules and precepts are insufficient to describe life as it is lived on the journey. It is for thick descriptions that one can turn to the narratives that were such a fertile source for Ambrose's teachings.

The importance of these models of the moral life inspired and guided by God, through Christ, is intrinsically tied to Ambrose's understanding of wisdom and morality as indistinguishable labels for the way of life to which Christians are called. His refusal or, better, his inability to separate the life of the Christian into compartments named faith, ethics, and knowledge speaks against all attempts to do so. In fact, such efforts would likely be seen by Ambrose as analogous to the fruitless dialectical debates of pagan philosophy, a certain sign that the debaters had disconnected themselves from their vital roots in scripture and in the acknowledgement of God as creator. Immersion in the originating stories of scripture teaches the reader that there is no faith without knowledge, no knowledge without faith, and neither faith nor knowledge can be said to exist if not manifested in moral conduct.

It is in his consistent vision of the way of wisdom, its identity with Christ as the wisdom of God and the way for human beings, and its revelation in the complexities of historical narratives that Ambrose can take a place 
within the history of Christian ethics, theology, and spirituality that parallels and even supersedes his importance as the forerunner of Augustine on the one hand and the medieval popes on the other. The unsystematic nature of Ambrose's thought has contributed to his being overshadowed by theologians like Augustine, but it is precisely his homiletic, narrative style -- rambling, colorful, dramatic, time-haunted -- that expresses so fittingly his vision of the moral and spiritual journey that christians undertake when they walk the path of true "philosophy": the love of wisdom that for Ambrose can only mean the faithful reception of christ. 
BIBLIOGRAPHIC ABBREVIATIONS

$\underline{\mathrm{CC}}$ Corpus Christianorum, Series Latina

CSEL Corpus Scriptorum Ecclesiasticorum Latinorum vols. 32.1 and 32.2 , ed. C. Schenkl vols. 62 and 64 , ed. M. Petschenig vol. 78, ed. O. Faller

$\underline{\text { PL }}$ Patrologia Latina, J.-P. Migne

\author{
ANCIENT WORKS CITED \\ (With abbreviations used)
}

Ambrose (with sources)

De Abraham (De Abr.), CSEL 32.1, 501-638

De bono mortis (De bon. mort.), CSEL 32.1, 703-53

De cain et Abel (De Cain), CSEL 32.1, 339-409

De excessu fratris (De exc. fratr.), PL 16, 1289-1354

De fide, CSEL 78

De fuga de saeculi (De fuga), CSEL 32.2, 163-207

De incarnatione, PL 16, 817-50

De institutione virginis, PL 16, 305-34

De interpellatione Job et David (De interpell.), CSEL 32.2, 211-96

De Isaac vel anima (De Isaac), CSEL 32.1, 641-700

De Jacob et vita beata (De Jacob), CSEL $32.2,3-70$

De Joseph (De Jos.), CSEL 32.2, 73-122

De mysteriis, PL 16, 389-410

De Noe, CSEL $32.1,413-97$ 
De officiis ministrorum (De off. min.), PL 16, 25-184 De paradiso (De par.), CSEL 32.1, 265-336

De sacramentis, PL $16,417-62$

De spiritu sancto, PL 16, 703-816

De viduis (De vid.), PL 16, 233-62

De virginibus, Corpus Scriptorum Latinorum

Paravianum, ed. E. Cazzaniga

De virginitate, PL 16, 265-302

Epistulae (Ep.), PL 16, 875-1286

Exameron (Exam.), CSEL 32.1, 3-261

Exhortatio virginitatis (Exh. virg.), PL 16, 335-64

Explanatio psalmorum XII (Explan.ps. no.), CSEL 64

Expositio evangelii secundum Lucam (Exp. evang. sec. LuC.), CC 14, 1-400

Expositio psalmi CXVIII (Exp.ps. 118), CSEL 62

Augustine

Confessiones (Conf.)

Cicero

De finibus bonorum et malorum (De finibus)

De inventione

De natura deorum

De officiis (De off.)

De senectute

Tusculanarum disputationum

Diogenes Laertius (DL) 
Philo

Quaetiones in Genesim (QGen)

Plato

Phaedrus

Seneca

Epistulae morales ad Lucilium (Ep. mor.)

Xenophon

Memorabilia 
REFERENCE LIST

Anderson, Knute. 1993. Review of De sacramentis, de mysteriis. über die sakramente, über die Mysterien, ed. and trans. by Josef Schmitz. In Journal of Early Christian Studies 1: 98-9.

Artz, Frederick B. 1980. The mind of the Middle Ages: an historical survey A.D. 200-1500. 3rd ed. Chicago: University of Chicago Press, Phoenix Books; first published University of Chicago Press, 1953.

Auf der Maur, H. J. 1977. Das Psalmenverstandnis des Ambrosius von Mailand. Leiden: E. J. Brill.

Balthasar, Hans Urs von. 1980. Nine theses in Christian ethics. In Readings in moral theology no. 2: the distinctiveness of Christian ethics, ed. Charles E. Curran and Richard A. McCormick, 190-206. New York: Paulist Press.

Baskin, J. R. 1981. Job as moral exemplar in Ambrose. Vigiliae Christianae 35: 222-31.

Beach, Waldo, and H. Richard Niebuhr. 1973. Christian ethics: sources of the living tradition. 2nd ed. New York: Knopf.

Berton, Raymond. 1980. Abraham dans le De officils ministrorum d'Ambroise. Revue des Sciences Religieuses 54: 311-22.

Blaise, Albert, and Henri Chirat. 1954. Dictionnaire Latin-Français des auteurs Chrétiens. Turnhout, Belgium: Brepols.

Brown, Peter. 1967. Augustine of Hippo. New York: Dorset; first published University of California Press.

- 1987. The saint as exemplar in late antiquity. In Saints and Virtues, ed. John stratton Hawley, 314. Berkeley: University of California Press.

- 1988. The body and society. New York: Columbia University Press.

Campenhausen, Hans von. 1929. Ambrosius von Mailand als Kirchenpolitiker. Berlin-Leipzig. 
Campenhausen Hans von. 1964. The fathers of the Latin

Church. Translated by Manfred Hoffman. London: Adam \& Charles Black.

Cantor, Norman F. 1993. The civilization of the Middle Ages. New York: Harper Collins.

Chadwick, Henry. 1967. The early Church. The Pelican History of the Church, ed. Owen Chadwick, no. 1. New York: Viking Penguin.

- 1993. Review of Hymnes, ed. by J. Fontaine and others. In Journal of Ecclesiastical History 44: 701-2.

Coleman, John A. 1987. Conclusion: after sainthood? In Saints and Virtues, ed. John stratton Hawley, 205-25. Berkeley: University of California Press.

Colish, Marcia L. 1990. Cicero, Ambrose, and Stoic ethics: transmission or transformation? In The classics in the Middle Ages: papers of the twentieth annual conference of the Center for Medieval and Early Renaissance Studies, ed. Aldo S. Bernardo and Saul Levin, 95-112. Binghamton, NY: Center for Medieval and Early Renaissance studies.

Copleston, Frederick C. 1990. A history of medieval philosophy. New York: Harper \& Row, 1972; reprint, Notre Dame, IN: University of Notre Dame Press.

Courcelle, Pierre. 1956. Nouveaux aspects du Platonisme chez Saint Ambroise. Revue des Études Latines 34: 220-39.

- 1962. L'Humanisme Chrétien de Saint Ambroise. Orpheus $9: 21-34$.

- 1963. Anti-Christian arguments and Christian Platonism: from Arnobius to St. Ambrose. In The conflict between paganism and christianity in the fourth century, ed. Arnaldo Momigliano, 151-92. Oxford: Clarendon Press.

- 1964. Deux grands courants de pensée dans la littérature latine tardive: Stoïcisme et Néoplatonisme. Revue des Études Latines 42: 122-40.

- 1968. Recherches sur les Confessions de Saint Augustin. 2nd ed. Paris: de Boccard. 
Courcelle, Pierre. 1973. Recherches sur Saint Ambroise: "vies" anciennes, culture, iconographie. Paris: Études Augustiniennes.

- 1974. Connais-toi toi-même de socrate à saint Bernard, 3 vols. Paris: Études Augustiniennes.

- 1976. Des sources antiques à l'iconographie médiévale de saint Ambroise. In Ambrosius Episcopus: Atti del congresso internazionale di studi ambrosiani nel XVI centenario della elavazione di sant'Ambrogio alla cattedra episcopale, Milan 2-7 December 1974, ed. G. Lazzati, 1: 171-202. Studia Patristica Mediolanensia, 6. Milan: Università Cattolica del Sacro Cuore.

Curran, Charles E. and Richard A. McCormick, eds. 1980. Readings in moral theology no. 2: the distinctiveness of Christian ethics. New York: Paulist Press.

Dalmais, I. H. 1993. Review of Hymnes, ed. by J. Fontaine and others. In Revue de l'Histoire des Religions 210: $360-2$.

Deman, Th. 1953. Le De officiis de Saint Ambroise dans l'histoire de la théologie morale. Revue des Sciences Philosophiques et Théologiques 37: 409-24.

Dihle, Albrecht. 1982. The theory of will in classical antiquity. Berkeley: University of California Press.

Dillon, John M. 1977. The middle Platonists: a study of Platonism, 80 B.C. to A.D. 220. London: Duckworth.

Dudden, F. Homes. 1935. The life and times of St. Ambrose. 2 vols. Oxford: The Clarendon Press.

Durand, G.-M. de. 1975. Review of Saint Ambroise et la philosophie, by Goulven Madec. In Revue des Sciences Philosophiques et Théologiques 59: 445-48.

Duval, Yves-Marie. 1975. Review of Saint Ambroise et la philosophie, by Goulven Madec. In Latomus 34: 798800 .

- 1976. Ambroise, de son élection à sa consecration. In Ambrosius Episcopus: Atti del congresso internazionale di studi ambrosiani nel XVI centenario della elavazione di sant'Ambrogio alla cattedra episcopale, Milan 2-7 December 1974, ed. G. Lazzati, 2: 243-83. Studia Patristica Mediolanensia, 27. Milan: Università Cattolica del Sacro Cuore. 
Ellspermann, Gerard L. 1984. The attitude of the early Christian Latin writers toward pagan literature and learning. The Catholic University of America Patristic Studies, vol. 82. Cleveland: John T. Zubal.

Ewald, Paul. 1881. Der Einfluss der stoischCiceronianischen Moral auf die Darstellung der Ethik bei Ambrosius. Leipzig: Pöschel \& Trepte.

Forell, George W. 1971. Christian social teachings. Minneapolis: Augsburg; first published Doubleday, 1966.

- 1979. History of Christian ethics. Vol. 1, From the New Testament to Augustine. Minneapolis: Augsburg.

Frede, Hermann J. 1976. Probleme des ambrosianischen Bibeltextes. In Ambrosius Episcopus: Atti del congresso internazionale di studi ambrosiani nel XVI centenario della elavazione di sant'Ambrogio alla cattedra episcopale, Milan 2-7 December 1974, ed. G. Lazzati, 1: 365-92. Studia Patristica Mediolanensia, 6. Milan: Università Cattolica del Sacro Cuore.

Frei, Hans W. 1974. The eclipse of biblical narrative: a study in eighteenth and nineteenth century hermeneutics. New Haven: Yale University Press.

Frend, W. H. C. 1982. The early Church. London: Hodder \& Stoughton, 1965; reprint, Philadelphia: Fortress Press.

Gaffney, James. 1981. Comparative religious ethics in the service of historical interpretation: Ambrose's use of Cicero. Journal of Religious Ethics 9: 35-47.

Gilson, Étienne. 1952. La philosophie au moyen age. 2nd ed. Paris: Payot.

Gustafson, James M. 1968. Christ and the moral life. Chicago: University of Chicago Press. - 1975. Can ethics be Christian? Chicago: University of Chicago Press.

Hadot, Pierre. 1956. Platon et Plotin dans trois sermons de Saint Ambroise. Revue des Études Latines 34: 20220 . 
Hadot, Pierre. 1979. Les divisions des parties de la philosophie dans l'antiquité. Museum Helveticum 36: 201-23.

Hagendahl, Harald. 1958. Latin fathers and the classics. Studia Graeca et Latina, no. 6. Göteborg.

Händler, Gert. 1978. Zur Auslegung der Psalmen in der alten Kirche. Theologische Literaturzeitung 103: 62532 .

Hauerwas, Stanley and David Burrell. 1989. From system to story: an alternative pattern for rationality in ethics. In why narrative? Readings in narrative theology, ed. Stanley Hauerwas and L. Gregory Jones, 158-90. Grand Rapids, MI: William P. Eerdmans.

Hauerwas, Stanley and L. Gregory Jones. 1989. Introduction: why narrative? In why narrative? Readings in narrative theology, ed. Stanley Hauerwas and L. Gregory Jones, 1-18. Grand Rapids, MI: William P. Eerdmans.

Hawley, John Stratton. 1987. Introduction: saints and virtues. In saints and Virtues, ed. John stratton Hawley, xi-xxiv. Berkeley: University of California Press.

Herrin, Judith. 1987. The formation of Christendom. Princeton: Princeton University Press.

Hiltbrunner, otto. 1964. Die Schrift De officiis ministrorum des hl. Ambrosius und ihr ciceronisches Vorbild. Gymnasium 71: 174-89.

Holte, Ragnar. 1962. Béatitude et sagesse. Paris: Études Augustiniennes.

Inwood, Brad. 1985. Ethics and human action in early Stoicism. Oxford: Clarendon Press.

Jacob, Christoph. 1990. "Arkandisziplin", Allegorese, Mystagogie: ein neuer Zugang zur Theologie des Ambrosius von Mailand. Theophaneia: Beiträge zur Religions- und Kirchengeschichte des Altertums, no. 32. Frankfurt: Anton Hain.

Lévi-strauss, claude. 1971. The structural study of myth. In Myth: a symposium, ed. Thomas A. Sebeok, 81-106. Bloomington, IN: Indiana University Press; first published Bibliographical and Special Series, vol. 5, The American Folklore Society, 1955. 
Long, A. A. 1986. Hellenistic philosophy: Stoics, Epicureans, Sceptics. 2nd ed. Berkeley: University of California Press.

Lucchesi, Enzo. 1977. L'usage de Philon dans l'oeuvre exégètique de Saint Ambroise: une "Quellenforschung" relative aux commentaires d'Ambroise sur la Genèse. Leiden: E. J. Brill.

MacIntyre, Alasdair. 1988. Whose justice? Which rationality? Notre Dame, IN: University of Notre Dame Press.

MacNamara, Vincent. 1985. Faith and ethics: recent Roman Catholicism. Washington, DC: Georgetown University Press.

Madec, Goulven. 1974a. Ambroise, Athanase et I'Apollinarisme. In Politique et théologie chez Athanase d'Alexandrie, ed. Charles Kannengiesser, 365-76. Théologie historique, ed. Charles Kannengiesser, no. 27. Paris: Beauchesne.

- 1974b. L'homme intérieur selon saint Ambroise. In Ambroise de Milan: XVI centenaire de son élection épiscopale, ed. Yves-Marie Duval, 283-308. Paris: Études Augustiniennes.

- 1974c. Saint Ambroise et la philosophie. Paris: Études Augustiniennes.

- 1977. Verus philosophus est amator dei: S. Ambroise, s. Augustin et la philosophie. Revue des Sciences Philosophiques et Théologiques. 61: 549-66.

Mähl, Sybille. 1969. Quadriga virtutum: die Kardinaltugenden in der Geistesgeschichte der Karolingerzeit. Cologne: Böhlau.

Marrou, Henri-Irénée. 1958. Saint Augustin et la fin de la culture antique. Paris: de Boccard.

McCormick, Richard A. 1980. Does religious faith add to ethical perception? In Readings in moral theology no. 2: the distinctiveness of Christian ethics, ed. Charles E. Curran and Richard A. McCormick, 156-73. New York: Paulist Press.

Meeks, Wayne A. 1986. The moral world of the first Christians. Philadelphia: Westminster Press. 
Meeks, Wayne A. 1993. The origins of Christian morality: the first two centuries. New Haven: Yale University Press.

Mohrmann, Christine. 1976. Observations sur le De sacramentis et le De mysteriis de saint Ambroise. In Ambrosius Episcopus: Atti del congresso internazionale di studi ambrosiani nel XVI centenario della elavazione di sant'Ambrogio alla cattedra episcopale, Milan 2-7 December 1974, ed. G. Lazzati, 1: 103-23. Studia Patristica Mediolanensia, 6. Milan: Università Cattolica del Sacro Cuore.

Muckle, J. T. 1939. The De officiis ministrorum of saint Ambrose: an example of the process of the Christianization of the Latin language. Mediaeval Studies 1: 63-80.

Muncey, Raymond W. L., ed. 1959. The New Testament text of st. Ambrose. Cambridge: Cambridge University Press.

Nauroy, Gérard. 1974. La méthode de composition et la structure du De Iacob et vita beata. In Ambroise de Milan: XVI ${ }^{e}$ centenaire de son élection épiscopale, ed. Yves-Marie Duval, 115-53. Paris: Études Augustiniennes.

- 1985a. La structure du De Isaac vel anima et la cohérence de l'allégorèse d'Ambroise de Milan. Revue des Études Latines 63: 210-36.

- 1985b. L'Écriture dans la pastorale d'Ambroise de Milan. In Le monde latin antique et la Bible, ed. Jacques Fontaine and Charles Pietri, 371-408. Paris: Beauchesne.

- 1990/1. Du combat de la piété à la confession du sang: Ambroise de Milan, lecteur critique du $\underline{I V}^{\mathrm{e}}$ livre des Maccabées. Revue d'Histoire et de Philosophie Religieuses 70: 49-68.

Niebuhr, H. Richard: 1951. Christ and culture. New York: Harper \& Row.

Nussbaum, Martha C. 1990. Form and content, philosophy and literature. In Love's knowledge: essays on philosophy and literature, by Martha C. Nussbaum, 3-53. New York: Oxford University Press.

- 1994. The therapy of desire: theory and practice in Hellenistic ethics. Martin Classical Lectures, New Series, vol. 2. Princeton: Princeton University Press. 
Oberhelman, Steven M. 1991. Rhetoric and homiletics in fourth-century Christian literature: prose rhythm, oratorical style and preaching in the works of Ambrose, Jerome, and Augustine. Atlanta: Scholars Press.

otten, R. T. 1966. Caritas and the ascent motif in the exegetical works of St. Ambrose. Studia Patristica 8 (part 2): 4.42-48.

Palanque, Jean-Rémy - 1933. Saint Ambroise et l'empire Romain. Paris: de Boccard.

Pannenberg, Wolfhart. 1976. Theology and the philosophy of science. Translated by Francis McDonagh. Philadelphia: Westminster Press.

Paredi, Angelo. 1964. Saint Ambrose, his life and times. Translated by M. J. Costelloe. Notre Dame, IN: University of Notre Dame Press.

Pelikan, Jaroslav. 1971. The emergence of the catholic tradition (100-600). Vol. 1, The Christian tradition: a history of the development of doctrine. Chicago: University of Chicago Press.

Pépin, Jean. 1976. Exégèse de "In principio" et théorie des principes dans 1 'Exameron (I 4, 12-16). In Ambrosius Episcopus: Atti del congresso internazionale di studi ambrosiani nel XVI centenario della elavazione di. sant'Ambrogio alla cattedra episcopale, Milan 2-7 December 1974, ed. G. Lazzati, 1: 427-82. Studia Patristica Mediolanensia, 6. Milan: Università Cattolica del Sacro Cuore.

Pizzolato, Luigi Franco. 1978. La dottrina esegetica di sant'Ambrogio. Milan: Università Cattolica del Sacro Cuore.

Previté-orton, C. W. 1952. The shorter Cambridge medieval history, 2 vols. Cambridge: Cambridge University Press.

Quasten, Johannes. 1986. Patrology. Vol. 4, The golden age of Latin patristic literature from the council of Nicaea to the Council of Chalcedon, ed. Angelo di Berardino. Westminster, MD: Christian Classics.

Rist, J. M. 1980. Stoic philosophy. Cambridge: Cambridge University Press; first published Cambridge University Press, 1969. 
Sagot, Solange. 1974. La triple sagesse dans le De Isaac uel anima. Essai sur les procédés de composition de saint Ambroise. In Ambroise de Milan: XVI

centenaire de son élection épiscopale, ed. Yves-Marie Duval, 67-114. Paris: Études Augustiniennes.

Savage, John J. 1961. Translation of De Cain et Abel, by Ambrose. In Saint Ambrose: Hexameron, Paradise, and Cain and Abel, trans. John J. Savage, 359-437. The Fathers of the Church, vol. 42. New York: Fathers of the Church, Inc.

Savon, Hervé. 1970. Quelques remarques sur la chronologie des oeuvres de Saint Ambroise. Studia Patristica 10 (part 1): 156-60.

- 1977a. Maniérisme et allégorie dans l'oeuvre d'Ambroise de Milan. Revue des Études Latines 55: 203-21.

- 1977b. Saint Ambroise devant l'exégèse de Philon le Juif, 2 vols. Paris: Études Augustiniennes.

- 1977c. Saint Ambroise et la philosophie à propos d'une étude récente. Revue de l'Histoire des

Religions 191: 173-96.

- 1984a. Le temps de l'exégèse allégorique dans la catéchèse d'Ambroise de Milan. In Le temps Chrétien de la fin de l'antiquité au Moyen Age III - XIII $^{e}$ siècles, ed. G.-M. Leroux, 345-61. Paris: Centre National de la Recherche Scientifique.

- 1984b. Saint Ambroise et saint Jérôme, lecteurs de Philon. Aufstieg und Niedergang der Römischen Welt II 21.1: 731-59.

Solignac, Aimé. 1956. Nouveaux parallèles entre Saint Ambroise et Plotin. Archives de Philosophie 19: 14856 .

- 1975. Review of Saint Ambroise et la philosophie, by Goulven Madec. In Archives de Philosophie 38:486-90.

Spanneut, Michel. 1973. Permanence du Stol̈cisme. Gembloux: J. Duculot.

Steidle, Wolf. 1984. Beobachtungen zu des Ambrosius Schrift De officiis. Vigiliae Christianae 38: 18-66. 
Steidle, Wolf. 1985. Beobachtungen zum Gedankengang im 2 . Buch von Ambrosius, De officiis. Vigiliae Christianae 39: 280-98.

Stelzenberger, Johannes. 1933. Die Beziehungen der frühchristlichen sittenlehre zur Ethik der stoa. Munich: Max Hueber.

Testard, Maurice. 1973. Observations sur le thème de la conscientia dans le De officiis ministrorum de saint Ambroise. Revue des Études Latines 51: 219-61.

- 1974. Étude sur la composition dans le De officiis ministrorum de saint Ambroise. In Ambroise de Milan: XVI centenaire de son élection épiscopale, ed. Yves-Marie Duval, 155-97. Paris: Études Augustiniennes.

- 1975. Review of Saint Ambroise et la philosophie, by Goulven Madec. In Revue des Études Augustiniennes 21: 213-15.

- 1984. Introduction and notes to Les Devoirs, by Ambrose, ed. and trans. by M. Testard, vol. 1. Paris: Société d'Édition "Les Belles Lettres".

- 1989. Recherches sur quelques méthodes de travail de Saint Ambroise dans le De officiis. Recherches Augustiniennes 24: 65-122.

Thamin, Raymond. 1895. Saint Ambroise et la morale Chrétienne au IV ${ }^{\mathrm{e}}$ siècle. Paris.

Tissot, Dom Gabriel. 1971. Introduction and notes to Traité sur l'évangile de $\mathrm{S}$. Luc, by Ambrose, trans. by G. Tissot, 2 vols. 2nd ed. Sources Chrétiennes no. 45. Paris: Les Éditions du Cerf.

Troeltsch, Ernst. 198i. The social teachings of the Christian churches, 2 vols. Translated by olive wyon. Chicago: University of Chicago Press.

Vanni Rovighi, Sofia. 1940. Le idee filosofiche di Sant'Ambrogio. In Sant'Ambrogio nel XVI centenario della nascità, 235-58. Milan.

Walker, Williston, and Richard A. Norris, David W. Lotz, and Robert T. Handy. 1985. A history of the Christian church. 4th ed. New York: Scribner.

Wallis, R. T. 1972. Neoplatonism. Classical Life and Letters, ed. Hugh Lloyd-Jones. London: Duckworth. 
Welter, J.-Th. 1973. L'exemplum dans la littérature religieuse et didactique du Moyen Âge. ParisToulouse, 1927; reprint, Geneva: Slatkine Reprints.

Wilken, Robert L. 1984a. Alexandria: a school for training in virtue. In schools of thought in the christian tradition, ed. Patrick Henry, 15-30. Philadelphia: Fortress Press. - 1984b. The Christians as the Romans saw them. New Haven: Yale University Press.

Zelzer, Klaus. 1977. Zur Beurteilung der Cicero-Imitatio bei Ambrosius, De officiis. Wiener studien 90: 16891 .

Zelzer, Michaela. 1987. Ambrosius von Mailand und das Erbe der klassischen Tradition. Wiener studien 100: 20126 . 